University of Pennsylvania Carey Law School

Penn Law: Legal Scholarship Repository

Faculty Scholarship at Penn Law

$12-1982$

\title{
Procedural Rulemaking Under the Judicial Councils Reform and Judicial Conduct and Disability Act of 1980
}

Stephen B. Burbank

University of Pennsylvania Carey Law School

Follow this and additional works at: https://scholarship.law.upenn.edu/faculty_scholarship

Part of the Civil Procedure Commons, Common Law Commons, Courts Commons, Disability Law Commons, Judges Commons, Legal Commons, Legal History Commons, and the Legislation Commons

\section{Repository Citation}

Burbank, Stephen B., "Procedural Rulemaking Under the Judicial Councils Reform and Judicial Conduct and Disability Act of 1980" (1982). Faculty Scholarship at Penn Law. 1397.

https://scholarship.law.upenn.edu/faculty_scholarship/1397

This Article is brought to you for free and open access by Penn Law: Legal Scholarship Repository. It has been accepted for inclusion in Faculty Scholarship at Penn Law by an authorized administrator of Penn Law: Legal Scholarship Repository. For more information, please contact PennlawIR@law.upenn.edu. 


\section{University of Pennsylvania \\ Law Review}

FOUNDED 1852

Formerly

American Law Register

\section{PROCEDURAL RULEMAKING UNDER THE JUDICIAL COUNCILS REFORM AND JUDICIAL CONDUCT AND DISABILITY ACT OF 1980}

\section{STEPHEN B. BurbanK $\uparrow$}

\section{INTRODUCTION}

The idea of enacting legislation to supplement the constitutional provisions for impeachment and removal of federal judges has long intrigued those discontent with the inefficiency of the constitutional arrangements. For years, congressional bills that included removal as a sanction for judicial misconduct foundered on opposition asserting that, to safeguard judicial independence, the framers had intended the constitutional arrangements to be exclusive. During the 1970's, when calls for public accountability of government officials respected no separation of powers, the idea's time had come. The Senate, where judicial discipline legislation had been reborn and nourished by a series of events

- Copyright 1982 by Stephen B. Burbank.

$\dagger$ Associate Professor of Law and Associate Dean, University of Pennsylvania. A.B. 1968, J.D. 1973, Harvard University.

Marc Rossell, LL.M. 1982, provided excellent research assistance.

This article was stimulated by my service as a co-reporter of rules to implement the Act in the Third Circuit. I wish to thank Chief Judge Collins Seitz for giving me an opportunity to work in this area, and my co-reporter, Daniel Segal, for his comments and suggestions on a draft of this Article. I am also indebted to Arlin Adams, Geoffrey Hazard, Leo Levin, Louis Pollak, Michael Remington, Maurice Rosenberg, Louis Schwartz, Murray Schwartz, Norma Shapiro, Stephen Subrin, and Alan Watson. William Weller and his staff in the Administrative Office of the United States Courts were generous with their time and the resources of the office. 
suggesting the inadequacy of judicial self-regulation, took the lead. Legislative proposals were refined, with the proponents of Senate bills monitoring the constitutional climate and the federal judiciary attempting to respond while weakened by division in the ranks. Fortunately for the judges, their leaders realized the precariousness of their position in time to grasp a helping hand offered by the House.

The memorable battles in this campaign were not fought over matters of procedure. Both in the Congress and in the literature, attention focused for many years on basic constitutional issues concerning the separation of powers and judicial independence. The position of the federal judiciary on these issues was not always clear even when legislative proposals included that most controversial provision, the power to remove. Eventually Congress agreed to drop removal as a sanction and accepted, not without considerable skepticism, the claims that the federal judiciary should in most cases take care of its own and that it could do so within existing institutions. In the process, residual arguments of unconstitutionality, lack of need, and unwise policy were overwhelmed by calls for public accountability and for clarification of the powers that be.

The Judicial Councils Reform and Judicial Conduct and Disability Act of $1980^{1}$ reposes primary authority to resolve complaints of judicial misconduct and disability in the judicial councils of the circuits, entities composed of federal judges that were established by Congress in 1939 as part of a more comprehensive program to improve the administration of the business of the federal courts. ${ }^{2}$ The Act provides for the

3 Pub. L. No. 96-458, 94 Stat. 2035 (1980) (effective Oct. 1, 1981). The Act's disciplinary procedures are contained id. $\S 3,94$ Stat. 2035, 2036-40 (codified at 28 U.S.C. § 372(c) (Supp. V 1981)).

The Act is compromise legislation. A Senate bill, S. 1873, 96th Cong., 1st Sess. (1979), was passed on October 30,1979. See 125 CONG. REC. 30,100-02 (1979). It dealt only with judicial conduct and disability. But pursuant to agreement, S. 1873 was added as an amendment to S. 1477, 96th Cong., Ist Sess. (1979), which included provisions for council reform and which, as so amended, was considered as having been read for a third time and passed. See 125 CoNG. REC. $23,242-43$ (1979); id. at 30,102.

The House alternative, H.R. 7974, 96th Cong., 2d Sess., 126 CONG. REC. H8784 (daily ed. Sept. 15, 1980), was passed on September 15, 1980. See 126 CONG. REC. H8788 (daily ed. Sept. 15,1980 ). It included provisions on both council reform and judicial conduct and disability. Thereafter, the House passed a bill that combined the enacting clause of S. 1873 and the remaining provisions of H.R. 7974. See id. at H8789-90. The Senate passed a "compromise substitute amendment," id. at S13,858 (daily ed. Sept. 30, 1980) (statement of Sen. DeConcini); see id. at $\mathrm{S} 13,866$, and the House concurred in the Senate amendment, see id. at H10,188-92 (daily ed. Oct. 1,1980 ).

The Act's background and legislative history are reviewed more fully infra text accompanying notes 24-106. Some understanding of these technical points may, however, be necessary in order to avoid misunderstanding and inaccuracy. See Culver \& Cruikshanks, Judicial Discipline at the Federal Level: A New Response to an Old Problem, in THE ANALYsis OF JUdicial REFORM 107 (P. Dubois ed. 1982).

2 The judicial councils of the circuits were created by the Administrative Office Act of 1939, 
restructuring of the councils to include district judge representation ${ }^{3}$ and sets forth in considerable detail the process to be followed in resolving complaints. The first step in that process is filing a complaint with the clerk of the court of appeals for the circuit. The chief judge of the circuit reviews the complaint, which he may dismiss if it does not meet statutory requirements, directly relates to the merits of a decision or procedural ruling, or is frivolous. The chief judge is also authorized "to conclude the proceeding if he finds that appropriate corrective action has been taken." Failing dismissal of the complaint or conclusion of

ch. 501, 53 Stat. 1223. Prior to 1981, the councils' powers derived from language that, as revised in 1948, codified, and amended, provided that "[e]ach judicial council shall make all necessary orders for the effective and expeditious administration of the business of the courts within its circuit. The district judges and bankruptcy judges shall promptly carry into effect all orders of the judicial council." 28 U.S.C. § 332(d) (Supp. III 1979) (amended 1980). For the history of the judicial councils within the administrative organization of the federal courts, see P. FiSH, THE POLITICS OF FEDERAL JUDICIAL ADMINISTRATION 125-65, 379-426 (1973); Fish, The Circuit Councils: Rusty Hinges of Federal Judicial Administration, 37 U. CHI. L. REV. 203 (1970).

3 See Pub. L. No. 96-458, § 2, 94 Stat. 2035, 2035-36 (1980) (amending 28 U.S.C. § 332 (1976)). This article is not concerned with that aspect of the Act, which is discussed in Remington, Circuit Council Reform: A Boat Hook for Judges and Court Administrators, 1981 B.Y.U. L. REV. 695.

Section 2, providing for district judge representation on the councils, was adopted primarily because Section 3 vests the councils with a primary role in the processing of complaints against judges and magistrates. The district judges insisted that they be represented on the councils if the councils were to exercise such sensitive authority.

Browning, Evaluating Judicial Performance and Related Matters, 90 F.R.D. 197, 201 (1981).

For the Act's ambiguities with respect to structural questions, see generally Neisser, The New Federal Judicial Discipline Act: Some Questions Congress Didn't Answer, 65 JUDichTURE 143, 147-51 (1981).

- (c)(1) Any person alleging that a circuit, district, or bankruptcy judge, or a magistrate, has engaged in conduct prejudicial to the effective and expeditious administration of the business of the courts, or alleging that such a judge or magistrate is unable to discharge all the duties of office by reason of mental or physical disability, may file with the clerk of the court of appeals for the circuit a written complaint containing a brief statement of the facts constituting such conduct.

28 U.S.C. \& 372(c)(1) (Supp. V 1981).

B (c) (2) Upon receipt of a complaint filed under paragraph (1) of this subsection, the clerk shall promptly transmit such complaint to the chief judge of the circuit, or, if the conduct complained of is that of the chief judge, to that circuit judge in regular active service next senior in date of commission (hereafter, for purposes of this subsection only, included in the term "chief judge"). The clerk shall simultaneously transmit a copy of the complaint to the judge or magistrate whose conduct is the subject of the complaint.

(c)(3) After expeditiously reviewing a complaint, the chief judge, by written order stating his reasons, may -

(A) dismiss the complaint, if he finds it to be (i) not in conformity with paragraph (1) of this subsection, (ii) directly related to the merits of a decision or procedural ruling, or (iii) frivolous; or

(B) conclude the proceeding if he finds that appropriate corrective action has been taken.

The chief judge shall transmit copies of his written order to the complainant and to the judge or magistrate whose conduct is the subject of the complaint.

28 U.S.C. $\S \S 372(c)(2)$-(3) (Supp. V 1981). 
the proceeding, the chief judge must appoint a special committee, consisting of the chief judge and equal numbers of circuit and district judges, to investigate the complaint and file with the council a report containing its findings and recommendations. ${ }^{6}$ The council, which is authorized to conduct any additional investigation it considers necessary, is directed to take such action "as is appropriate to assure the effective and expeditious administration of the business of the courts within the circuit, including, but not limited to," actions specifically enumerated in the Act. ${ }^{\text {? }}$

- (c)(4) If the chief judge does not enter an order under paragraph (3) of this subsection, such judge shall promptly -

(A) appoint himself and equal numbers of circuit and district judges of the circuit to a special committee to investigate the facts and allegations contained in the complaint;

(B) certify the complaint and any other documents pertaining thereto to each member of such committee; and

(C) provide written notice to the complainant and the judge or magistrate whose conduct is the subject of the complaint of the action taken under this paragraph.

(c)(5) Each committee appointed under paragraph (4) of this subsection shall conduct an investigation as extensive as it considers necessary, and shall expeditiously file a comprehensive written report thereon with the judicial council of the circuit. Such report shall present both the findings of the investigation and the committee's recommendations for necessary and appropriate action by the judicial council of the circuit.

28 U.S.C. $\S \S 372(c)(4)-(5)$ (Supp. V 1981).

(c)6) Upon receipt of a report filed under paragraph (5) of this subsection, the judicial council -

(A) may conduct any additional investigation which it considers to be necessary;

(B) shall take such action as is appropriate to assure the effective and expeditious administration of the business of the courts within the circuit, including, but not limited to, any of the following actions:

(i) directing the chief judge of the district of the magistrate whose conduct is the subject of the complaint to take such action as the judicial council considers appropriate;

(ii) certifying disability of a judge appointed to hold office during good behavior whose conduct is the subject of the complaint, pursuant to the procedures and standards provided under subsection (b) of this section;

(iii) requesting that any such judge appointed to hold office during good behavior voluntarily retire, with the provision that the length of service requirements under section 371 of this title shall not apply; (iv) ordering that, on a temporary basis for a time certain, no further cases be assigned to any judge or magistrate whose conduct is the subject of a complaint;

(v) censuring or reprimanding such judge or magistrate by means of private communication;

(vi) censuring or reprimanding such judge or magistrate by means of public announcement; or

(vii) ordering such other action as it considers appropriate under the circumstances, except that (I) in no circumstances may the council order removal from office of any judge appointed to hold office during good behavior, and (II) any removal of a magistrate shall be in accordance with section 631 of this title and any removal of a bank- 
In addition, the Act authorizes petitions for review by the complainant or the subject of a complaint to the council from the action of a chief judge in dismissing a complaint or concluding the proceeding, and to the Judicial Conference of the United States ${ }^{8}$ from the action of a judicial council upon receipt of a report from a special committee. ${ }^{9} \mathrm{Fi}$ nally, the Act specifies a number of procedural details, primarily notice requirements, ${ }^{10}$ and, although conferring on the councils rulemaking authority to implement the statutory process, requires that certain provisions be contained in any rules that are promulgated. ${ }^{11}$ Thus, although leaving most matters of judicial misconduct and

ruptcy judge shall be in accordance with section 153 of this title; and

(C) shall immediately provide written notice to the complainant and to such judge or magistrate of the action taken under this paragraph.

28 U.S.C. \& 372(c)(6) (Supp. V 1981).

- For the history of the Judicial Conference within the administrative organization of the federal courts, see P. FISH, supra note 2, at 228-68. The Conference's general powers and responsibilities are set forth in 28 U.S.C. § 331 (Supp. V 1981). In addition to its role in entertaining petitions for review of council action under the Act, see infra note 9, the Conference is empowered to modify any council rule and itself to prescribe rules. See infra note 11.

- (c)(10) A complainant, judge, or magistrate aggrieved by a final order of the chief judge under paragraph (3) of this subsection may petition the judicial council for review thereof. A complainant, judge, or magistrate aggrieved by an action of the judicial council under paragraph (6) of this subsection may petition the Judicial Conference of the United States for review thereof. The Judicial Conference, or the standing committee established under section 331 of this title, may grant a petition filed by a complainant, judge, or magistrate under this paragraph. Except as expressly provided in this paragraph, all orders and determinations, including denials of petitions for review, shall be final and conclusive and shall not be judicially reviewable on appeal or otherwise.

28 U.S.C. § 372(c)(10) (Supp. V 1981).

10 See, e.g., 28 U.S.C. $\S 372(c)(2)$ (Supp. V 1981), quoted supra note 5; id. § 372 (c)(4), quoted supra note 6 .

11 (c)(11) Each judicial council and the Judicial Conference may prescribe such rules for the conduct of proceedings under this subsection, including the processing of petitions for review, as each considers to be appropriate. Such rules shall contain provisions requiring that -

(A) adequate prior notice of any investigation be given in writing to the judge or magistrate whose conduct is the subject of the complaint;

(B) the judge or magistrate whose conduct is the subject of the complaint be afforded an opportunity to appear (in person or by counsel) at proceedings conducted by the investigating panel, to present oral and documentary evidence, to compel the attendance of witnesses or the production of documents, to cross-examine witnesses, and to present argument orally or in writing; and

(C) the complainant be afforded an opportunity to appear at proceedings conducted by the investigating panel, if the panel concludes that the complainant could offer substantial information.

Any rule promulgated under this subsection shall be a matter of public record, and any such rule promulgated by a judicial council may be modified by the Judicial Conference.

28 U.S.C. $\S 372(c)(11)$ (Supp. V 1981).

Under § 4 of the Act, 28 U.S.C. § 331 (Supp. V 1981), the Judicial Conference of the United States "may also prescribe and modify rules for the exercise of the authority provided in section 372(c) of this title." For further discussion, see infra note 98 and accompanying text. 
disability to the federal judiciary itself, the Act is not without direction. Most of it, however, is procedural. ${ }^{12}$ The major substantive question presented by judicial discipline legislation - the types of conduct subject to disciplinary action - remains in large part unanswered. ${ }^{13}$

It is appropriate now, more than two years after the statute was enacted and one year after its effective date, to assess the capacity of the Act, as implemented by the judiciary, to fulfill the purposes for which it was designed. Congress sought to establish a mechanism that would enable the federal judiciary to deal authoritatively, fairly, and efficiently with misconduct and disability complaints against federal judges and magistrates, with the goals of improving judicial ethics and judicial accountability to the public while preserving the essentials of judicial independence. ${ }^{14}$

Of course, it is too early for a comprehensive assessment of selfregulation under the Act. That can come only when more complaints have been resolved and when that experience is available for analysis. The decentralized system that the judiciary has put in place is, however, of immediate interest. For reported experience under the Act to date suggests that it may be a long time before enough complaints have tested the councils' procedures, other than procedures for dismissal, to permit a useful evaluation in practice. ${ }^{16}$ When confronted with a similar situation before the Act was passed, Congress was unwilling to stay its hand, and the Act's legislative history suggests that "vigorous oversight" by Congress may result in amendments less deferential to the principles of judicial independence and decentralized judicial administration. ${ }^{16}$ If the councils' implementation of the Act is found wanting,

12 See supra text accompanying notes 5-11. The statutory process is schematically represented in a chart distributed by the Administrative Office of the United States Courts, which is reprinted in Re, Judicial Independence and Accountability: The Judicial Councils Reform and Judicial Conduct and Disability Act of 1980, 8 N. KY. L. REV. 221, 258 (1981).

${ }^{23}$ The Act's standards of both misconduct and disability are contained in the provision authorizing the filing of a complaint. See supra note 4.

16 The purpose of the proposed legislation is to create a mechanism and procedures within the judicial branch of government to consider and respond to complaints against Federal judges. A secondary purpose of the legislation is to revise the composition of the judicial councils of the Federal judicial circuits, and to clarify the authority of both the circuit councils and the Judicial Conference of the United States in the area of judicial discipline and disability. The goals of the proposed legislation are to improve judicial accountability and ethics, to promote respect for the principle that the appearance of justice is an integral element of this country's justice system, and, at the same time, to maintain the independence and autonomy of the judicial branch of government.

H.R. REP. No. 1313, 96th Cong., 2d Sess. 1 (1980) [hereinafter cited as HouSE REPORT].

This Article is not concerned with the Act's "secondary purpose . . . to revise the composition of the judicial councils of the Federal judicial circuits." Id.; see supra note 3.

${ }_{13}$ See infra text accompanying notes 164-65; notes 257 \& 276; Appendix B.

16 See, e.g., 126 CONG. REC. H8788 (daily ed. Sept. 15, 1980) (statement of Rep. Butler); id. 
Congress may not permit the judiciary to clean its own house again. Moreover, although the judicial councils of the circuits are authorized to promulgate rules for the conduct of proceedings, the Judicial Conference is empowered to modify any council rule so promulgated as well as to prescribe rules. ${ }^{17}$ If the need is there, the judiciary has the means to act now, before Congress reacts.

Eleven circuit councils have promulgated revised rules to implement the Act, which became effective October 1, 1981; the Judicial Council of the Tenth Gircuit continues to use rules that were first adopted in November, 1978.18 An analysis of post-Act rules raises questions about the potential of decentralized implementation efforts to serve Congress's purposes and to achieve Congress's goals.

First, most of the sets of rules promulgated by the judicial councils of the circuits do little more than track the provisions of the Act. ${ }^{19}$ They leave important matters undefined, including the procedure that will be followed by special committees and the councils in investigating and resolving complaints and by the councils in handling petitions for review. Although there are reasons, including some good reasons, that

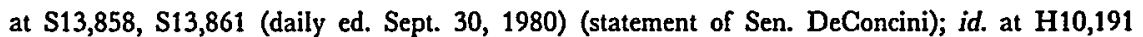
(daily ed. Oct. 1, 1980) (statement of Rep. Kastenmeier); see also HOUSE REPORT, supra note 14, at 20; id. at 31 (supplemental views of Hon. M. Caldwell Butler); Re, supra note 12, at 255-56; Remington, supra note 3, at 731; infra note 106.

For Congress's refusal to defer legislation pending the accumulation of experience under the councils' post-March 1979 rules, which were severely criticized, see infra text accompanying notes 58-65; note 276.

Decentralization is, of course, a relative concept. As a result of the 1939 Act, see supra note 2, federal judicial administration is decentralized in comparison with an alternative system that would have reposed significant administrative responsibilities in the Supreme Court. See P. FISH, supra note 2 , at $125-65$. It is not decentralized in comparison with the regime of individual court autonomy that had previously obtained. See id. at 3-14. For the view that "[t]he extent of actual decentralization has been minimal," see J. MCDERMOTT \& S. FLANDERS, THE IMPACT OF THE CIRCUIT EXECUTIVE ACT 193-94 (1979) [hereinafter cited as MCDERMOTT \& FLANDERS].

17 See supra note 11.

18 The rules of the Second, Fourth, Fifth, and Ninth Circuit Councils, as amended through February 1, 1982, are included in the cumulative annual pocket part of 28 U.S.C.A. Rules. The rules of the Third Circuit Council are published in 688 F.2d No. 3 (Nov. 1, 1982) (yellow pages). The rules of the Eleventh Circuit Council are published in 694 F.2d No. 3 (Jan. 24, 1983) (yellow pages) (addendum three). Copies of all of the councils' rules are on file with the University of Pennsylvania Law Review. All councils except that of the Eleventh Circuit, which did not exist prior to the Act's effective date, had preexisting rules on the subject.

10 28 U.S.C. $\$ 372(c)(17)$ (Supp. V 1981) requires the Court of Claims, the Court of Customs and Patent Appeals, and the Customs Court to "prescribe rules, consistent with the foregoing provisions of this subsection, establishing procedures for the filing of complaints with respect to the conduct of any judge of such court and for the investigation and resolution of such complaints." By the Federal Courts Improvement Act of 1982, Pub. L. No. 97-164, § 112(c), 96 Stat. 25, 29, this section was amended "by striking out "Court of Claims, the Court of Customs and Patent Appeals, and the Customs Court' and inserting in lieu thereof 'United States Claims Court, the Court of International Trade, and the Court of Appeals for the Federal Circuit." "

Although this Article does not discuss the rules promulgated by the specialized courts, they are included in the analytical table, infra Appendix A. As quickly appears, the tendency to track the Act is particularly striking in these sets of rules. 
can be adduced to explain this phenomenon, it is doubtful that they justify the degree of minimalism that marks council rulemaking under the Act. The councils' choice not to elaborate statutory process and procedure has impeded experimentation, the putative benefits of which furnished the primary argument against uniform rules. It entails uncertainty and unpredictability and thus disserves Congress's goals of ensuring public accountability and preserving judicial independence. Finally, the councils' choice of rulemaking minimalism raises questions regarding the efficiency of the implementation efforts. ${ }^{20}$

Second, the rules of the various councils, insofar as they depart from the statutory skeleton, are not uniform in a number of provisions. This was to be expected - indeed to be hoped for - in the initial rulemaking, and Congress, in the grant of rulemaking authority to the Judicial Conference, has provided a means for its correction. Disuniformity in some aspects is of no concern. In others, it invites claims of unequal treatment that are unlikely to be satisfied by a defense of local experimentation. As a result of the councils' approach to rulemaking, however, the Judicial Conference does not know what procedures will be used on many questions in most circuits. The possibility of intercircuit conflict in procedure.is, therefore, a more serious problem for the Conference than the existence of conflict. ${ }^{21}$

Third, some of the rules promulgated by the councils are inconsistent with the Act's specific procedural directives, animating policies, or grant of rulemaking authority. ${ }^{22}$

Fourth, if one views public accountability as a discrete congressional goal, both the rulemaking and the reporting under the Act to date are causes for concern. Neither the processes used to develop the councils' rules nor the efforts to make those rules known to the public suggest that the federal judiciary has embraced this goal. The methods presently used to report on the operation of the system established by Congress are such that, even when there has been more experience, a comprehensive assessment will be difficult if not impossible - another reason to evaluate now the system established by council rules. ${ }^{23}$

The federal judiciary has the means to make the Act serve, and be perceived to serve, Congress's purposes and goals. The Judicial Conference should use its powers under the Act to eliminate unwarranted disuniformity and rules that are inconsistent with the Act's provisions or its policies. If, as may be the case, continued exclusive reliance on local

2s See infra text accompanying notes 243-70. 
rulemaking by the councils is inappropriate, the Conference should also use its powers to fashion model rules that better serve those policies, affording the councils choice among alternatives where continuing experimentation is warranted. The federal judiciary should cooperate in identifying and furnishing information that, without sacrificing legitimate interests in confidentiality, will assist Congress and the public in determining whether the purposes and goals of the Act are in fact being well served. The history of the Act suggests that if the judiciary does not address these problems, Congress will.

\section{The ACt's History}

A brief review of the Act's background and legislative history not only informs our understanding of Congress's choices. It also provides a basis for evaluating the decentralized system of self-regulation created by the federal judiciary to implement the Act, the methods by which that system was created, and the adequacy of the information available for its evaluation in practice. Finally, such a review helps explain the course the councils have chosen and the considerations that should or will influence the Judicial Conference and Congress in responding to those efforts.

\section{A. Background}

1. The Senate Proposes and the Judicial Conference Responds

a. The Tydings Bills

A number of developments prompted Senator Tydings to revive judicial discipline legislation in the mid-1960's. ${ }^{24}$ The effectiveness of

34 See 111 CONG. REc. 27,105 (1965) (statement of Sen. Tydings); see also Tydings, The Congress and the Courts: Helping the Judiciary to Help Itself, 52 A.B.A. J. 321 (1966).

Tydings's bills found their antecedents in bills introduced in the 1930's and 1940's. For accounts of this history, see AMERICAN ENTERPRISE INSTITUTE, JUDICIAL DISGIPLINE AND TENURE Proposals 3-4 (1979), reprinted in Judicial Tenure and Discipline 1979-80: Hearings Before the Subcomm. on Courts, Civil Liberties, and the Administration of Justice of the House Comm. on the Judiciary, 96th Cong., 1st \& 2d Sess. 511-12 (1980) [hereinafter cited as House Hearings]; Holloman, The Judicial Reform Act: History, Analysis, and Comment, 35 LAW \& CONTEMP. PROBS. 128, 131-33 (1970); Kurland, The Constitution and the Tenure of Federal Judges: Some Notes from History, 36 U. CHI. L. REV. 665, 687-93 (1969), reprinted in Hearings on S. 295, S. 522, S. 678 Before the Subcomm. on Judicial Machinery and Constitution of the Senate Comm. on the Judiciary, 96th Cong., 1st Sess. 408-14 (1979) [hereinafter cited as Senate Hearings); Wallace, Must We Have the Nunn Bill? The Alternative of Judicial Councils of the Circuits, 51 IND. L.J. 297, 302-03 (1976), reprinted in House Hearings, supra, at 332-33. Some of the relevant earlier history is reviewed in Kurland, supra, at 670-87.

It is enough for present purposes to note that the only sanction the early bills provided was removal, thus rendering them vulnerable, notwithstanding then-recent scholarship, to claims of unconstitutionality. See Shartel, Federal Judges - Appointment, Supervision, and Removal - 
the judicial councils in dealing even with matters of judicial administration unquestionably within their purview had been challenged. ${ }^{25}$ In addition, there was evidence that the problem of the misbehaving or disabled federal judge was more serious than previously recognized and that impeachment was an inadequate mechanism for addressing it. ${ }^{28}$ Finally, starting in 1960 , the states had developed mechanisms to address the problem that seemed to be effective. ${ }^{27}$ But Senator Tydings's bills, which were heavily influenced by state models, ${ }^{28}$ foundered on by then familiar ground - the argument that the Constitution provides the exclusive means to remove federal judges - protected by Senator Ervin, a formidable guardian. ${ }^{29}$

\section{b. The Nunn/DeConcini Bill}

In 1974, when Senator Nunn took charge of the effort, Watergate was on everybody's mind. ${ }^{30}$ Moreover, the ranks of those who believed that the constitutional obstacles to legislation authorizing the removal of an article III judge were surmountable had grown, ${ }^{31}$ and their case was

Some Possibilities Under the Constitution, 28 MICH. L. REv. 485, 723, 870 (1930). But see Otis, A Proposed Tribunal: Is it Constitutional?, 7 U. KaN. CrTY L. REV. 1 (1938).

${ }_{25}$ See, e.g., STAFF OF SENATE COMM. ON APPROPRIATIONS, 86TH CONG., 1ST SESS., Field STUDY OF THE OPERATIONS OF THE UNITED STATES COURTS 3, 32, 34-44, 79-84b (Comm. Print 1959); A REPORT OF THE JUDICIAL CONFERENCE OF THE UNITED STATES, H.R. DOC. NO. 201, 87th Cong., 1st Sess. v-vi (1961); Burger, The Courts on Trial, 22 F.R.D. 71, 77, 82 (1958); Lumbard, The Place of the Federal Judicial Councils in the Administration of the Courts, 47 A.B.A. J. 169,170 (1961).

36 See, e.g., 111 CONG. REC. 27,108 (1965) (statement of Sen. Tydings); Holloman, supra note 24, at 133; Tydings, supra note 24 , at 322 .

${ }^{27}$ See I. TESITOR \& D. SiNKS, JUDICIAL CONDUCT ORGanizations 2 (2d ed. 1980) [hereinafter cited as TESITOR \& SINKS]; Tydings, supra note 24 , at 324 . By 1980, 49 states and the District of Columbia had adopted "disciplinary systems other than the traditional but seldom used methods of impeachment, address, and concurrent resolution." TESITOR \& SINKS, supra, at v.

For the effect of judicial and political developments on Senator Tydings's proposals during the time they were being formulated and considered, see Holloman, supra note 24, at 134-44; see also Tydings, supra note 24 , at 322-23. Senator Tydings himself later provided an account of the history of his efforts and of the opposition he encountered. See Judicial Tenure Act: Hearing on $S$. 1423 Before the Subcomm. on Improvements in Judicial Machinery of the Senate Comm. on the Judiciary, 95th Cong., 1st Sess. 61-62 (1977) [hereinafter cited as Hearing on S. 1423] (statement of Mr. Tydings).

${ }_{23}$ See Hearing on S. 1423, supra note 27, at 62, 78, 93 (statement of Mr. Tydings).

29 See Ervin, Separation of Powers: Judicial Independence, 35 LAW \& CONTEMP. PROBS. $108,121-27$ (1970); see also Holloman, supra note 24, at 135-36, 142-44. In his testimony on S. 1423, 95th Cong., 1st Sess. (1977), Tydings noted Ervin's opposition, Hearing on S. 1423, supra note 27 , at 81 , but seemed preoccupied by that of Judge Richard Chambers. See id. at 77 , 81.

so Nunn introduced his first bill on the subject, S. 4153, 93d Cong., 2d Sess. (1974), in October 1974. Hearing on $S$. 1423, supra note 27, at 33 (statement of Sen. Nunn). For the influence of Watergate, see id. at 31; see also House Hearings, supra note 24, at 131 (statement of Rep. Rodino). For other suggested influences, see R. WHEELER \& A. LEVIN, JUDICIAL DISCIPLINE AND REMOVAL IN THE UNITED STATES 43 (1979) [hereinafter cited as WHEELER \& LEVIN], reprinted in House Hearings, supra note 24 , at 663.

s1 See, e.g., R. BERGER, IMPEACHMENT: THE CONSTTTUTIONAL PROBlems ch. 4 (1973). 
not hurt by the Judicial Conference's responses to Nunn's proposals. ${ }^{32}$ In March 1978 the Conference considered S. 1423, a bill co-sponsored by Senators Nunn and DeConcini that included removal, a Judicial Conduct and Disability Commission, and a Court on Judicial Conduct and Disability; the Conference's approval in principle of that bill, although accompanied by a constitutional caveat about removal and a few suggested amendments, was "widely misunderstood." Conference had clarified its position in September 1978, the Nunn/ DeConcini bill had passed in the Senate. ${ }^{34}$ S. 1423 was not acted on in the House in the Ninety-Fifth Congress, however.

The Senate's action on the Nunn/DeConcini bill made it clear to the Judicial Conference that it would need to play a more active and assertive role in the legislative process. Many believed that the prospect of a central investigative bureaucracy, a special court, and adversary proceedings, as called for by the Nunn/DeConcini bill, was the prospect of harassment. ${ }^{35}$ Moreover, like its predecessors, the Nunn/ DeConcini bill departed from the philosophy of decentralized judicial administration that had prevailed since the legislation establishing the

32 The Conference had approved judicial discipline legislation "in principle" for many years. See House Hearings, supra note 24, at 60-61 (statement of Judge Elmo B. Hunter). Although such expressions of approval were accompanied by caveats about the constitutionality of removal provisions in the bills, in 1969 a committee of the Conference recommended approval of Senator Tydings's bill, S. 1506, 91st Cong., 1st Sess. (1969), that included removal. Report of the Proceedings of the Judicial Conference of the United States 53 (Oct. 1969). The matter was referred back to the committee. Id. Moreover, in its 1975 comments on Nunn's bill, S. 4153, supra note 30 , the Conference suggested that "a judge . . . may be mandatorily (or involuntarily) retired [as opposed to removed] for serious misconduct and he may be relieved of any further judicial duties." Report of the Proceedings of the Judicial Conference of the United States 5 (Mar. 1975).

ss S. 1423, supra note 29. Following the Conference's action on S. 1423, see Report of the Proceedings of the Judicial Conference of the United States 6-7 (Mar. 1978), the Chief Justice stated: "There will be some legislation. In general, the approach of Senator Nunn, and now, of Senator DeConcini, has been found acceptable by the Judicial Conference of the United States. I think that it will prove to be a very useful device." Proceedings of the Thirty-Ninth Annual Judicial Conference of the District of Columbia Circuit, 81 F.R.D. 263, 278 (1978).

In these circumstances, it is understandable that the Conference's position on S. 1423 was "widely misunderstood" and that the Conference felt the need to make clear its "disapproval of any legislative provision which purports to delegate to any other tribunal or entity the constitutional power of Congress to remove a federal judge from office." Report of the Proceedings of the Judicial Conference of the United States 50 (Sept. 1978); see also House Hearings, supra note 24, at 61, 63-64 (statement of Judge Hunter); id. at 92-93 (statement of Judge Hunter).

8s S. 1423, as amended by the Senate Judiciary Committee and on the floor, passed in the Senate on September 7, 1978. See 124 CONG. REC. 28,321 (1978). The Conference's response to widespread misunderstanding of its March 1978 comments on S. 1423 was made at its meeting on September 21-22. See supra note 33.

2s See, e.g., Senate Hearings, supra note 24, at 28-29 (statement of Judge Hunter); House Hearings, supra note 24, at 65-66 (statement of Judge Hunter); Wallace, The Nunn Bill: An Unneeded Compromise of Judicial Independence, 61 JUDICATURE 476 (1978), reprinted in House Hearings, supra note 24, at 357. Senator Nunn introduced S. 295, 96th Cong., 1st Sess. (1979), upon which Judge Hunter was commenting, on January 31, 1979. It was identical to $S .1423$ as passed by the Senate in September 1978. 125 CONG. REC. 1449 (1979) (statement of Sen. Nunn). 
judicial councils of the circuits in $1939 . .^{38}$ Enactment of the bill would have constituted a rejection of the claims of the organized federal judiciary that it was capable of self-regulation within the existing structure. ${ }^{37}$ At the same time, some judges resisted those claims of existing power, ${ }^{38}$ and other critics doubted the councils' willingness to exercise it. ${ }^{39}$ These attacks on the status quo tended to disarm those who argued that there was - and to make pragmatists of those who wished that there were - no need for additional legislation clarifying the councils' powers. A study by the Conference's Committee on Court Administration, requested in September 1978, resulted in proposed legislation. ${ }^{40}$

28 See sources cited supra note 35; supra note 2; WHEELER \& LEVIN, supra note 30, at 2836. For the possibility that the word "rhetoric" should be substituted for "philosophy," see supra note 16.

${ }^{37}$ As noted by Senator Nunn, "[t] uous and has been cited as authority by parties on both sides of the discipline issue." Nunn, Judicial Tenure, 54 CHI.-KENT L. REV. 29, 34 (1977). Whatever may have been the originally intended limits on the authority of the councils to deal formally with problems of judicial misconduct or disability, the Conference and some councils had become progressively more expansive in asserting that authority. See, e.g., P. FISH, supra note 2, at 400-04, 417-26; Wallace, supra note 24, at 311-23. In 1961, the Conference approved a report on the responsibilities and powers of the judicial councils. Report of the Proceedings of the Judicial Conference of the United States 51-53 (Mar. 1961). One of the Conference's conclusions is of particular interest:

(2) The responsibility of the Councils "for the effective and expeditious administration of the business of the courts within its circuit" extends not merely to the business of the courts in its technical sense (Judicial administration), such as the handling and dispatching of cases, but also to the business of the judiciary in its institutional sense (administration of justice), such as the avoiding of any stigma, disrepute, or other element of loss of public esteem and confidence in respect to the court system, from the actions of a judge or other person attached to the courts.

Id. at 51 (emphasis added), reprinted in H.R. Doc. No. 201, 87th Cong., 1st Sess. 8-9 (1961).

The Conference reasserted this proposition in a statement entitled "Powers, Functions and Duties of Circuit Councils" approved in 1974. See Report of the Proceedings of the Judicial Conference of the United States 8 (Mar. 1974).

With respect to disability as opposed to misconduct, 28 U.S.C. § 372(b) (Supp. V 1981) had for many years provided a means calculated to persuade a reluctant judge to retire. It was rarely invoked, however. See WHEELER \& LEVIN, supra note 30, at 34; Kaufman, Chilling Judicial Independence, 88 YALE L.J. 681, 708-09 (1979), reprinted in Senate Hearings, supra note 24, at 314-15, and House Hearings, supra note 24, at 576-77; Tydings, supra note 24, at 324.

se See, e.g., Chandler v. Judicial Council of the Tenth Circuit, 398 U.S. 74, 129 (1970) (Douglas, J., dissenting); 398 U.S. at 141 (Black, J., dissenting); Battisti, An Independent Judiciary or an Evanescent Dream, 25 CASE W. RES. L. REV. 711 (1975); see also Comment, The Authority of the Circuit Judicial Councils: Separation of Powers in the Courts of Appeals, 5 SETON HALL L. REV. 815 (1974).

so See, e.g., P. FisH, supra note 2, at 404-09; Hearing on S. 1423, supra note 27, at 79 (statement of Mr. Tydings). These doubts persisted. See, e.g., HOUSE REPORT, supra note 14, at 7. Certainly, the public record of the councils' efforts hardly inspired confidence. See, e.g., Tydings, supra note 24, at 322-23; Comment, supra note 38. For an argument that this is not a fair basis of evaluation given the councils' preference for informal techniques, see S. FLANDERS \& J. MCDERMOTT, OPERATION OF THE FEDERAL JUDICIAL COUNCILS 26-35 (1978) [hereinafter cited as FLANDERS \& MCDERMOTT]; WHEELER \& LEVIN, supra note 30, at 49-59. For the influence of Chandler v. Judicial Council of the Tenth Circuit, 398 U.S. 74 (1970), on councils' willingness to proceed formally, see WHEELER \& LEVIN, supra note 30, at 38.

10 In addition to clarifying its position on removal at the September 1978 meeting, see supra note 32, the Conference directed "its Committee on Court Administration to conduct a study to 


\section{c. Alternatives to the Nunn/DeConcini Bill}

The Senate's action on S. 1423 also stimulated further activity in Congress. In the Senate, alternatives to the Nunn/DeConcini bill ${ }^{41}$ were introduced early in 1979 by Senators Bayh ${ }^{42}$ and Kennedy. ${ }^{43}$ These alternatives differed in important respects. But they both rejected removal by means other than those constitutionally prescribed and built on the premise that, except in cases where impeachment might be warranted, complaints alleging judicial misconduct or disability should be resolved by the judiciary acting through existing mechanisms. ${ }^{44}$

Within weeks after the Bayh and Kennedy bills were introduced, the Judicial Conference considered proposed amendments to 28 U.S.G. $\S 332,{ }^{40}$ the statutory provision from which the councils derived their

determine whether legislation is necessary to clarify the power of the judicial councils of the circuits to adopt procedures for the examination of judicial conduct in cases where it is warranted and to take appropriate action with respect to such instances." Report of the Proceedings of the Judicial Conference of the United States 50 (Sept. 1978). As authoritatively reported, "[t]he purpose of this second resolution [was] obviously to recommend proposals which might be necessary to set up procedures which would make it possible for the Judicial Branch to deal with judicial misbehavior through revisions of existing administrative machinery." Judicial Conference Calls for Changes in Judicial Tenure Bill, THIRD BRANCH, Oct. 1978, at 2. For the Committee's proposed legislation, see Senate Hearings, supra note 24, at 24 (statement of Judge Hunter); House Hearings, supra note 24, at 61-62 (statement of Judge Hunter); infra note 45 and accompanying text.

11 For the introduction of S. 295, supra note 35 , which was identical to S. 1423, see supra note 35 .

${ }^{42}$ See S. 522, 96th Cong., 1st Sess. (1979), reprinted in Senate Hearings, supra note 24, at 160. Senator Bayh introduced S. 522 on March 1, 1979. See 125 CONG. REC. 3685 (1979). Notwithstanding Senator Mathias' ultimate position that "impeachment is not only the sole constitutional means of removing miscreant judges, it is the sole constitutionally permissible means of disciplining federal judges," House Hearings, supra note 24, at 154, Mathias had been a cosponsor of S. 522. Although sharing Mathias' concern for judicial independence, Senator Bayh appears to have recognized that legislation of some sort would be passed and that demurrers to the "more drastic" provisions of the Nunn/DeConcini bill, S. REP. No. 1035, 95th Cong., 2d Sess. 70 (1978), were not an adequate substitute for specific alternative proposals. See 125 CONG. REC. 3685-86 (1979); see also Protecting Judges - and the Public, N.Y. Times, Jan. 22, 1979, at A20, col. 1.

4s See S. 678, 96th Cong., 1st Sess. (1979), reprinted in Senate Hearings, supra note 24, at 168. Senator Kennedy introduced S. 678 on March 15, 1979. See 125 CoNG. REC. 5229-30 (1979). Title I, part E of this bill, of which Senator DeConcini was a co-sponsor, concerned judicial discipline. Kennedy acknowledged that, whatever the record of the federal judiciary in the past, the massive increase in the number of federal judges effected by the Omnibus Judgeship Bill, Pub. L. No. 95-486, 92 Stat. 1629 (1978), was reason enough to predict more problems in the future. See Kennedy, The Federal Courts Improvement Act: A First Step for Congress to Take, 63 JUDICATURE 8, 11 (1979). Senator Bayh shared that concern, see 125 CONG. REC. 3685 (1979), as did Senator DeConcini, see 125 CONG. REC. 1454 (1979). See also Hearing on S. 1423, supra note 27, at $89-90$ (statement of Attorney General Bell).

4 Both bills also included authority to impose specifically enumerated sanctions. For analyses of the bills, see Senate Hearings, supra note 24, at 28-30 (statement of Judge Hunter); WHEELER \& LEVIN, supra note 30, at 47-48; see also infra note 85.

4528 U.S.C. $\S 332$ (1976) (amended 1980). On § 332, see supra note 2. For the chronology of Conference action, see Senate Hearings, supra note 24, at 24-25 (statement of Judge Hunter); House Hearings, supra note 24, at 61-62 (statement of Judge Hunter). The proposed amendments of the Court Administration Committee (which were recommended prior to the introduction 
powers. A resolution adopted at the March 1979 meeting of the Conference approved "principles to be reflected in any legislation dealing with procedures for inquiries into the conduct of Federal judges." 46 The Conference also recommended that the councils formulate and promulgate rules, and directed the revision of the Court Administration Committee's legislative proposals, in accordance with those principles. ${ }^{47}$

Thus, by the time hearings were held on the various judicial discipline bills introduced in the Senate, the Judicial Conference, although not advocating legislation, had expressed a position on the basic shape that any such legislation should take. In addition, the Conference's resolution had made clear that, when it approved draft amendments to 28 U.S.G. $\S 332$, they would be much closer to the Bayh or Kennedy bills than to the Nunn/DeConcini bill." Finally, by providing that "[a]ll previous Judicial Conference resolutions or comments upon legislation dealing with the conduct of Federal judges are superseded by this resolution,"49 the Conference had sought finally to dispel any ambiguity

of the Kennedy and Bayh bills) can be found in Senate Hearings, supra note 24, at 490-503.

18 (a) Removal of an article III judge from office by any method other than impeachment as provided in article I of the Constitution would raise grave constitutional questions which should be avoided.

(b) The primary responsibility for dealing with a complaint against a U.S. judge should rest initially with the chief judge of the circuit as presiding judge of the Judicial Council, who may dismiss the complaint if it is frivolous or relates to the merits of a decision or procedural ruling, or may close the complaint after assuring himself that appropriate corrective action has been taken.

(c) Any complaint not dismissed or closed by the presiding judge should be referred to a committee appointed by the presiding judge, consisting of an equal number of circuit and district judges and the presiding judge.

(d) The joint committee should report its findings and recommendations to the Judicial Council, which should take such action as is appropriate to assure the effective and expeditious administration of the business of the courts within the circuit.

(e) The Judicial Council may, in its discretion, refer a complaint and the Council's recommended action to the Judicial Conference of the United States.

(f) If the Judicial Council concludes that grounds for impeachment may exist, it should transmit the record upon which its conclusion is based to the Judicial Conference of the United States; the Judical Conference shall then determine whether, in all the circumstances, the matter should be referred to the House of Representatives.

Report of the Proceedings of the Judicial Conference of the United States 5 (Mar. 1979), reprinted in Senate Hearings, supra note 24, at 25, and House Hearings, supra note 24, at 62-63.

${ }^{47}$ See id. at 5-6. This resolution included other provisions not discussed in the text. See, e.g., infra text accompanying note 49 . Moreover, at the same meeting, the Conference adopted a resolution approving "principles to be reflected in any legislation dealing with the membership of the Judicial Councils of the circuits," which included district judge representation. Report of the Proceedings of the Judicial Conference of the United States 6-7 (Mar. 1979), reprinted in Senate Hearings, supra note 24, at 30 , and House Hearings, supra note 24, at 66-67. Both the Bayh and Kennedy bills also addressed this issue, see Senate Hearings, supra note 24 , at 161,179 , as did the legislative proposals of the Court Administration Committee, id. at 492.

18 See supra text accompanying notes $34-37 \& 44$. For the change of focus from $\S 332$ to 28 U.S.C. § 372 (1976) (amended 1980), see infra note 66.

49 Report of the Proceedings of the Judicial Conference of the United States 6 (Mar. 1979), 
arising from its previous pronouncements and to speak with one voice. But the senators heard more than one voice at the hearings. Individual judges continued to disagree about the need for additional legislation and the shape that any such legislation should take. ${ }^{\text {so }}$

\section{d. $S .1873$}

The passage of S. 1423 by the Senate and the determination of Senators Nunn and DeConcini ensured Senate consideration of some judicial discipline legislation in the first session of the Ninety-Sixth Congress. Doubts about the adequacy of existing arrangements and of the legislation proposed by the Judicial Conference caused members of the Senate to work with representatives of the Conference in drafting a compromise bill, introduced as S. 1873. ${ }^{61}$ The bill did not purport to authorize removal, and it endowed the councils with first-line responsibility. But S. 1873 was irreconcilable with the existing structure and theory of federal judicial administration and thus proved unacceptable to the Judicial Conference. ${ }^{52}$ Those in Congress who had consulted the

reprinted in Senate Hearings, supra note 24, at 25, and House Hearings, supra note 24, at 63; see supra note 32 and accompanying text.

Bo In addition to the Senate Hearings, supra note 24, Senator Kennedy held hearings on his bill, S. 678 , supra note 43 , and on a similar bill sponsored by the Administration, S. 677, 96th Cong., 1st Sess. (1979), at which there was some testimony concerning S. 678's discipline provisions. See Hearings on S. 677 and S. 678 Before the Subcomm. on Improvements in Judicial Machinery of the Senate Comm. on the Judiciary, 96th Cong., 1st Sess. (1979) (hereinafter cited as Hearings on $S .677$ and $S .678$ ].

Opinions from judges at the two sets of hearings included support for the Nunn/DeConcini bill, see Senate Hearings, supra note 24, at 46-48 (statement of Judge Lumbard), support for the Kennedy or Bayh bills, see Hearings on S. 677 and S. 678, supra, at 5 (statement of Chief Judge Coffin); Senate Hearings, supra note 24, at 253 (statement submitted by Judge Adams), and the recommendation that Congress defer legislation until there had been time to evaluate experience under rules promulgated by the councils pursuant to the March 1979 Conference resolution, see Hearings on S. 677 and S. 678, supra, at 26 (statement of Judge Newman). Not even those who had labored on behalf of the Conference agreed about what should be done. The Conference's authorized spokesman, Judge Hunter, and Chief Judge Browning expressed the view that statutory amendments along the lines indicated by the March 1979 Conference resolution were desirable even if not necessary. See Senate Hearings, supra note 24, at 24, 26 (statement of Judge Hunter); id. at 43, 45 (statement of Chief Judge Browning). Judge Wallace, on the other hand, favored a very minor change in the existing statutory language. See id. at 36,40 (statement of Judge Wallace).

${ }^{81} \mathrm{~S}$. 1873 ; supra note 1 . The process of compromise in the Senate had begun before the 96th Congress. Indeed, the Judicial Conference of the District of Columbia Circuit had been urged to "adopt, in principle, and recommend the adoption of" the Nunn/DeConcini bill on the grounds that Senator Nunn had changed his bill in response to the recommendation of the Judicial Conference and that it was "very important, that we follow along with this agreement." Proceedings of the Thirty-Ninth Annual Judicial Conference of the District of Columbia Circuit, 81 F.R.D. 263, 341-42 (1978) (statements of Judge Tamm and Chief Judge Wright).

Members of the Senate and their stafts "worked very closely and amicably with the judicial conference in ... efforts to draft ... legislation" and "made many accommodations to their views." 125 CoNG. RF. 30,063 (1979) (statement of Sen. Bayh).

s2 The bill, which is reprinted in House Hearings, supra note 24 , at 311 , would have created a special court with power to review actions of the judicial councils and to conduct de novo hear- 
Conference in drafting S. 1873 rejected and probably resented its attempt to defeat the bill. ${ }^{53}$ The Conference's efforts were not unavailing, however. Even with a broad-based group of sponsors, S. 1873 passed only with difficulty, encountering stiff opposition on the Senate floor. ${ }^{84}$

\section{Patience and Progress in the House}

The House, which had not actively considered judicial discipline legislation for many years, ${ }^{\mathrm{ss}}$ was exposed to an even greater number of legislative proposals than the Senate in the first session of the NinetySixth Congress. ${ }^{3 B}$ But it was the House, in which positions on the issues had not hardened, attitudes toward particular approaches were not proprietary, and patience with the judiciary had not been exhausted, that bore major responsibility for fashioning the ultimate compromise legislation enacted in 1980.

The hearing record in the Senate had been closed in mid-1979. But when the House Subcommittee on Courts, Civil Liberties, and the

ings. It was thought to portend a more elaborate and adversary process than was warranted by the record and in light of the concern for judicial independence. In these respects, among others, S. 1873 sustained prudential and even constitutional opposition, although it neither authorized removal nor established a bureaucracy outside the judiciary. See, e.g., HOUSE REPORT, supra note 14, at 4, 18-19; Kaufman, The Essence of Judicial Independence, 80 COLUM. L. REv. 671, 697700 (1980); sources cited infra note 53.

The Judicial Conference found S. 1873 unacceptable, and Judge Elmo Hunter, the Chairman of the Conference's Court Administration Committee, so informed each member of the Senate in a four-page letter, the conclusions of which were summarized by Judge Hunter as follows:

In summary, the Judicial Conference believes:

1. that the objectives which $S .1873$ is designed to achieve are already available through existing processes and procedures;

2. that legislation is therefore not now necessary;

3. that existing procedures will more responsively and responsibly resolve complaints in less time than would S. 1873; and

4. that, if legislative action is to be taken, it should consist of statutorily authorizing those existing processes and procedures not yet expressly embodied in title 28 of the United States Code, but applicable by rule in ten of the eleven judicial circuits.

Letter from Hon. Elmo B. Hunter to all Senators (Oct. 22, 1979) (copy on file with the University of Pennsylvania Law Review).

Bs Senator Bayh stated on the floor that, in light of the accommodations made to the judiciary in S. 1873, he "was somewhat disappointed . . . to learn a few days ago that the Judicial Conference Committee working on the issue has informed the Members of the Senate by letter that it considers S. 1873 unacceptable." 125 CONG. REC. 30,063 (1979). His remarks thereafter were clearly in response to the arguments made in Judge Hunter's letter. See id. at 30,063-64.

In addition to Judge Hunter's letter, senators apparently received many telephone calls from federal judges. See 125 CONG. REC. 30,087 (1979) (statement of Sen. Nunn).

34 See 125 CONG. REC. 30,052-53 (1979) (statement of Sen. Laxalt); id. at 30,056-58, 30,095-96 (statements of Sen. Mathias); id. at 30,058 (statement of Sen. Heflin). The bill passed 56-33, with 11 Senators not voting. Id. at 30,100 .

Bs See HOUSE REPORT, supra note 14, at 6. But see H.R. 9042, 95th Cong., 1st Sess. 123 CONG. REC. 28,892 (1977) (introduced by Rep. Kastenmeier).

${ }_{\text {Bo }}$ The various House bills introduced prior to the opening of the House hearings on July 12, 1979, are reproduced in House Hearings, supra note 24, at 222-88. 
Administration of Justice, chaired by Representative Kastenmeier, adjourned on July 13,1979, it was "subject to the call of the Chair," to be reconvened "sometime in the future." Congressman Kastenmeier took his time in reconvening his subcommittee's hearings. ${ }^{58} \mathrm{~S} .1873$ had been passed in the Senate, but not without substantial opposition. Kastenmeier himself had introduced the legislative proposals of the Judicial Conference as H.R. $6330 .^{58}$ Most of the judicial councils of the circuits had promulgated rules pursuant to the March 1979 recommendation of the Conference. Whereas Judge Elmo Hunter had argued that the councils' action was reason enough for Congress to stay its hand, ${ }^{60}$ others drew the contrary inference. Criticism of the councils' rules for incompleteness and disuniformity came from a number of sources. ${ }^{61}$ Elaborated by the spokesman of the Department of Justice, ${ }^{62}$ which continued to support "earlier proposals," such as the Nunn/ DeConcini bill, ${ }^{\text {bs }}$ that criticism was difficult to ignore. In light of the Senate's action, the seemingly equivocal position of the Judicial Confer-

87 Id. at 123-24; see also HOUSE REPORT, supra note 14, at 6 . The testimony prior to adjournment largely duplicated that at the Senate hearings, see House Hearings, supra note 24, at 1124, but because only Judges Hunter and Wallace and Chief Judge Browning appeared for the judiciary, the testimony suggested greater unanimity within the judiciary than actually exişted. Judge Wallace, however, continued to argue for very minor statutory amendments. See id. at 74; supra note 50. Moreover, he disagreed with Judge Hunter's view that the Conference's actions after the passage of S. 1423, the Nunn/DeConcini bill, did not represent a change in position. See House Hearings, supra note 24, at 92-93.

ss Almost nine months separated the first two days of hearings (July 12 and 13,1979 ) from the second (March 27 and 31, 1980). The purpose of the recess was to permit "the Members and staff . . . further [to] investigate the need for the legislation and . . . delineate the effects it would have on the independence and autonomy of all three branches of government." HOUSE REPORT, supra note 14 , at 6 .

so H.R. 6330, 96th Cong., 2d Sess. (1980), reprinted in House Hearings, supra note 24, at 304. Representative Kastenmeier introduced H.R. 6330 on Jan. 29, 1980. See 126 CoNG. REC. H387 (daily ed. Jan. 29, 1980). For the bill's provenance, see House Hearings, supra note 24, at 126.

${ }^{60}$ See letter from Hon. Elmo B. Hunter to all Senators, supra note 52; see also S. REP. NO. 362, 96th Cong., 1st Sess. 27 (1979) [hereinafter cited as SENATE REPORT] (additional views of Sen. Mathias); supra note 50.

-2 See, e.g., letter from Herbert H. Anderson to Robert W. Kastenmeier (May 22, 1980), reprinted in House Hearings, supra note 24, at 204.

e2 See House Hearings, supra note 24, at 161-62, 165-67 (statement of Assistant Attorney General Maurice Rosenberg); see also Federal Circuit Councils Adopt Disciplinary Rules, JUDICIAL CONDUCT REPORTER, Spring 1980, at 1-4; infra note 180. This criticism was accepted by Congress. See HOUSE REPORT, supra note 14, at 4; see also id. at 31 (supplemental views of Rep. Butler); 126 CONG. REC. H8786 (daily ed. Sept. 15, 1980) (statement of Rep. Railsback); id. at H8788 (statement of Rep. Butler); id. at S13,859 (daily ed. Sept. 30, 1980) (statement of Sen. DeConcini).

63 House Hearings, supra note 24, at 163 (statement of Assistant Attorney General Rosenberg). In 1980, the ABA's House of Delegates adopted a resolution that supported in principle both the Nunn/DeConcini bill and S. 1873, among others. SUMMARY OF ACTION TAKEN BY THE HOUSE OF DELEGATES OF THE AMERICAN BAR ASSOCIATION 20 (1980). The same body declined to adopt a recommendation urging Congress to defer action until experience under the councils' post-March 1979 procedures demonstrated whether legislation was required. See id. at 18. 
ence, ${ }^{64}$ criticism of the councils' rules, and continuing support for the Nunn/DeConcini bill, cooperation with the federal judiciary signalled legislation, not abdication. ${ }^{65}$

\section{B. Congress's Choices}

\section{Specification of Process}

Against this background, it is easier to understand the reasons for the shape the legislation ultimately assumed. Specification of the process for resolving complaints within the judiciary had, in the end, become the focus of legislative debate. Moreover, some specification had been sought, albeit not consistently, by the Judicial Conference, and the post-March 1979 rules of the judicial councils had been criticized for silence or inconsistency on important aspects of the process they contemplated.

The House used as its basic model the bill approved by the Judicial Conference, H.R. $6330,{ }^{68}$ the structure of which was also reflected in part in the Bayh and Kennedy bills. All of these bills endowed the judicial councils with the primary responsibility to resolve complaints of judicial misconduct or disability, and H.R. 6330 and the Bayh bill incorporated prior screening by the chief judge. ${ }^{67}$ The arguments in favor of the latter feature, apart from the Conference's endorsement, stressed efficiency and informal collegial resolution of complaints. ${ }^{68}$ Some of the same arguments bore on the choice between review by a special court, as proposed by S. 1873 , and review by the Judicial Conference, as proposed by H.R. 6330 and the Kennedy bill. ${ }^{69}$ Here, however, other considerations came into play that were also relevant to the substantive question of standards for disciplinary action. The idea of

-4 See supra notes 50, 52 \& 53. But see HOUSE REPORT, supra note 14, at 4-5 (Conference supported "the establishment of uniform rules through congressional action").

es The desire to cooperate with the federal judiciary was evident in the remarks of Chairman Kastenmeier and others on the subcommittee. See, e.g., House Hearings, supra note 24, at 174 (Rep. Kastenmeier); id. at 182 (Rep. Mazzoli).

is See supra text accompanying note 59; HOUSE REPORT, supra note 14, at 6 . Although the Conference's March 1979 resolution contemplated that legislation clarifying the councils' powers would amend 28 U.S.C. $\S 332$, see supra text accompanying notes $45-47$, the bill finally approved by the Conference proposed the amendment of 28 U.S.C. $\$ 372$ (1976) (amended 1980). See Report of the Proceedings of the Judicial Conference of the United States 57 (Sept. 1979).

77 See Senate Hearings, supra note 24, at 29 (statement of Judge Hunter); House Hearings, supra note 24 , at $305-06$.

os See supra text accompanying note 46; Senate Hearings, supra note 24, at 29 (statement of Judge Hunter); 126 CONG. REC. S13,859, 13,860 (daily ed. Sept. 30, 1980) (statement of Sen. DeConcini); letter from Hon. Elmo B. Hunter to all Senators, supra note 52.

-O See Senate Hearings, supra note 24, at 29 (statement of Judge Hunter); House Hearings, supra note 24, at 308 . For the arguments, see HOUSE REPORT, supra note 14, at 4, 18-19; letter from Hon. Elmo B. Hunter to all Senators, supra note 52. 
"judicial administration" took on a life of its own.

As judicial misconduct and disability legislation was refined in Congress, the position of those who maintained constitutional objections to any legislative proposal in the area became progressively uncomfortable. These judges, legislators, and scholars were confronted by the existence of legislation that the Judicial Conference and some councils regarded as authority enough to deal with problems of misconduct or disability. ${ }^{70}$ Senator Bayh well stated their conundrum: "If these [sic] are indeed serious constitutional questions with any legislative grants of authority to the judicial branch to practice discipline, then in all good conscience . . . we should act today to strike section 332 from the United States Code."71 Faced with an unpalatable choice, people of this mind were driven to fine distinctions between judicial discipline and judicial administration and to subtle inquiries into intent. ${ }^{\mathbf{7 2}}$ For those who supported, or at least could live with, additional legislation, such distinctions, however opaque, became arguments for adherence to the fundamentals of the existing system of judicial administration: $:^{73}$ adversary proceedings in a special court surely look adjudicatory rather than administrative. ${ }^{74}$

\section{Substantive Ambiguity}

However it might be expressed, disagreement about standards for judicial discipline was not about judicial as opposed to administrative

70 See supra note 37 and accompanying text.

72125 CONG. REC. 30,063 (1979).

72 See, e.g., House Hearings, supra note 24, at 38-39, 45 (statement of Monroe Freedman); Kaufman, supra note 37 , at $708-09$.

72 See, e.g., Senate Hearings, supra note 24, at 35-42 (statement of Judge Wallace); id. at 58 (statement of Chief Judge Browning); House Hearings, supra note 24, at 73-79 (statement of Judge Wallace); id. at 90-91 (statement of Chief Judge Browning); see also Wallace, supra note 25; Wallace, supra note 35.

76 While the Conference's March resolution and its draft bill both provide for review by the Judicial Conference itself, we believe the relative undesirability of review by a "special court" is founded upon the type of remedial action being taken. Circuit councils are not trial courts. Even under the very formal processes required by S. 1873 their functions would not be truly adjudicatory, nor would they really be proceeding in a traditional adversary setting. Nor should they. The issues before them will not be matters of guilt or innocence, liability or lack of it; the issues will be, and should be, questions concerning the "administration of the business of the courts." Most of those issues will be resolved with administrative remedies. Only a few may be of such serious weight that they will require actual "adjudication." In those few cases, we believe that impeachment under Article I of the Constitution should be utilized - even if it is cumbersome. If a judge's conduct is beyond an administrative remedy, then the body constitutionally authorized to adjudicate that judge's behavior should do so without any "prejudgment" of the question.

Letter from Hon. Elmo B. Hunter to all Senators, supra note 52 (emphasis in original). 
power, but about the extent to which Congress and the judiciary could and should go in regulating the conduct of federal judges. There was agreement that misconduct or disability could not be predicated on the merits of a judge's or magistrate's rulings. ${ }^{75}$ Similarly, concern for judicial independence had prompted a consensus that any legislative mechanism must provide for the speedy dismissal of frivolous complaints or complaints not within the jurisdiction conferred by the statute. ${ }^{76}$ There remained, however, ample room for disagreement about the ambit of that jurisdiction. The state models drawn on in S. 1423 and S. 295, the Nunn/DeConcini bill, ${ }^{77}$ and referred to in the Senate Judiciary Committee's report on $S .1873,{ }^{78}$ suggested that the regulatory reach

75 See, e.g., SENATE REPORT, supra note 60 , at 8; HOUSE REPORT, supra note 14 , at 10,18 19; see also House Hearings, supra note 24 , at 27 (statement of Sen. DeConcini). Under the Act:

(c)(3) After expeditiously reviewing a complaint, the chief judge, by written order stating his reasons, may -

(A) dismiss the complaint, if he finds it to be (i) not in conformity with paragraph (1) of this subsection; (ii) directly related to the merits of a decision or procedural ruling, or (iii) frivolous; or

(B) conclude the proceeding if he finds that appropriate corrective action has been taken. . . .

28 U.S.C. § 372(c)(3) (Supp. V 1981) (emphasis added).

A complaint "not in conformity with paragraph (1) of this subsection" includes one that does not allege "that a circuit, district, or bankruptcy judge, or a magistrate, has engaged in conduct prejudicial to the effective and expeditious administration of the business of the courts," or that "such a judge or magistrate is unable to discharge all of the duties of office by reason of mental or physical disability." See Neisser, supra note 3, at 152. Review of final orders rendered by the chief judge under this section may be sought by petition to the Judicial Council. 28 U.S.C. $\$ 372$ (c)(10) (Supp. V 1981), quoted supra note 9.

76 Senator Mathias objected that S. 1873 failed "to deal with clearly frivolous and non-meritorious complaints with expediency and finality," because it did not authorize screening by the Chief Judge. House Hearings, supra note 24, at 158 (statement of Sen. Mathias). The Senate report on S. 1873, however, noted approval of such a procedure, implemented by local rule. See SENATE REPORT, supra note 60 , at 8 . The Conference was concerned that "[u]nder S. 1873 every complaint can potentially be "bootstrapped" to full review by the special court." Letter from Hon. Elmo B. Hunter to all Senators, supra note 52. For the Act's resolution of this problem, see supra note 75; infra note 166; see also supra text accompanying notes 67-68; HOUSE REPORT, supra note 14, at 10; 126 CONG. REC. S13,859-60 (daily ed. Sept. 30, 1980) (statement of Sen. DeConcini).

77 S. 295, supra note 35 . In perpetuating the Nunn/DeConcini bill's "good behavior" standard, Senator Kennedy took on a load of empty baggage. See S. 678 , supra note $43, \S 141$, reprinted in Senate Hearings, supra note 24, at 182 . It is not just that the standard was a red flag likely to keep alive constitutional debate that the elimination of removal was designed to quiet. See, e.g., Senate Hearings, supra note 24, at 119 (statement of Paul Bender). That very debate raised the question whether the words had any ascertainable content. Compare Kaufman, supra note 37, with Berger, "Chilling Judicial Independence": A Scarecrow, 64 CORNELL L. REV. 822 (1979), reprinted in House Hearings, supra note 24, at 585; see also REPORT ON S. 678 AND S. 862 BY THE COMMITTEE ON FEDERAL COURTS OF THE ASSOCIATION OF THE BAR OF THE CITY OF NEW YORK (1979), reprinted in House Hearings, supra note 24, at 826 . The Nunn/DeConcini bill had attempted to fill the gap, resorting to state models for statutory definitions. See S. $1423, \S 388$; S. $295, \S 388$, reprinted in Senate Hearings, supra note 24, at 146-47; S. REP. No. 1035 , 95th Cong., $2 d$ Sess. $32-36$ (1978); see also WHEELER \& LEVIN, supra note 30, at 4546.

78 S. 1873 abandoned "good behavior" in favor of the standard under which the councils had been operating since 1948. See S. 1873, reprinted in House Hearings, supra note 24, at 312; supra note 37 . But it may not, and should not, have gone unnoticed that the definitions, although 
was long indeed, extending to a great variety of conduct not directly related to the performance of official functions. ${ }^{79}$ On the other hand, the report seemed to disclaim any such purpose, ${ }^{80}$ and Senator Bayh emphasized the Act's limited jurisdiction. ${ }^{81}$

It is not surprising that the House eschewed a detailed elaboration of the standard for disciplinary action in the bill it passed and in the bill's legislative history. ${ }^{82}$ The language adopted by the House and

no longer part of the statute, continued to be invoked, and state models continued to be cited, in the Senate Judiciary Committee's report. See SENATE REPORT, supra note 60, at 8-9. The origins of this part of the Senate report, see S. REP. NO. 1035, 95th Cong., 2d Sess. 32-36 (1978); supra note 77, provide an explanation for sentences in it that are otherwise incomprehensible. See, e.g., SENATE REPORT, supra note 60 , at 9 ("If it is true that the specified grounds for [sic] becoming 'terms of art', the Committee does not believe that it should attempt in this report to add a legislative gloss to the terms.").

70 For.an analysis of the state experience, see Martineau, Disciplining Judges for Nonofficial Conduct: A Survey and Critique of the Law, $10 \mathrm{U}$. BALT. L. REV. 225 (1981). The amendments proposed by the Judicial Conference's Committee on Court Administration would have permitted a complaint to allege that the subject of the complaint "has engaged or is engaging in conduct prejudicial to the administration of justice by bringing the judicial office into disrepute." Senate Hearings, supra note 24, at 494. Such a standard was also part of S. 1873 until the full Judiciary Committee markup, when it was deleted at the suggestion of Senator Bayh, "because it was felt that this standard could be too intrusive on the judge's personal life and was subject to possible abuse." 125 CONG. REC. 30,050 (1979) (statement of Sen. Thurmond); see Neisser, supra note 3, at 152. By that time as well, the Conference had thought better of the standard, and the Administrative Office of the United States Courts had also requested its deletion. See 125 CONG. REC. 30,050 (1979) (statement of Sen. Thurmond). Nonetheless, the report on S. 1873 stated that the standard finally adopted, with which the judiciary was familiar, see supra note 78 , included, among other things, "conduct prejudicial to the administration of justice that brings the judicial office into disrepute." SENATE REPORT, supra note 60, at 9. For further critical comment on the standard, see WHEELER \& LEVIN, supra note 30 , at 64 \& n.156.

so "Complaints relating to the conduct of a member of the judiciary which are not connected with the judicial office or which do not affect the administration of justice are without jurisdiction and therefore outside the scope of this legislation." SENATE REPORT, supra note 60, at 3; see also id. at 6 . The problem, of course, is cabining the notion of effect. See Martineau, supra note 79, at $237-45$.

82 "Extrajudicial habits and behavior are outside the reach of the bill. It is only when a judge's behavior affects his performance on the bench that a complaint is valid." 125 CONG. REC. 30,064 (1979) (statement of Sen. Bayh) (emphasis added); see also Senate Hearings, supra note 24 , at 60 .

82 See HOUSE REPORT, supra note 14, at 10; infra note 85. The Nunn/DeConcini laundry list of definitions, let alone a reference to state law, would have raised questions of consistency with the "inquisitorial-administrative" model the House purported to adopt. See HOUSE REPORT, supra note 14, at 4-5, 24; see also House Hearings, supra note 24, at 42 (statement of Rep. Kastenmeier).

The basic thrust of the federal procedure is different from that of state disciplinary procedures. The process established by Section 3 of the federal Act is deliberately drawn to an administrative model rather than an adjudicatory one. Its primary purpose is not to ferret out and punish offending judges but to improve the functioning of the court by solving administrative problems. This difference is reflected in many ways. Most state disciplinary agencies are independent of the judiciary and include lay members; state processes are generally directed against "wilful misconduct in office" or "conduct prejudicial to the administration of justice that brings the judicial office into disrepute." The federal statute establishes a procedure entirely within the judiciary. As I have noted, the approach is not adjudicatory but administrative. The procedures are not directed primarily at the judge but at the functioning of the court. The process is initiated not by alleging "misconduct" or "conduct 
agreed to by the Senate - "conduct prejudicial to the effective and expeditious administration of the business of the courts" - was familiar to the judiciary ${ }^{83}$ and had been sought by the Judicial Conference, which, if there was to be legislation, was concerned about clarifying power thought to exist. ${ }^{84}$ Substantively, the judges must rely in the future, as they relied in the past, on their colleagues to protect judicial independence. $^{\mathbf{8 s}}$

that brings the judicial office into disrepute," but by alleging "conduct prejudicial to the effective and expeditious administration of the business of the courts."

Browning, supra note 3, at 204.

More important, an attempt at definitional precision would have been controversial. See supra text accompanying notes 77-81; see also H. FRIENDLY, BENCHMARKS 128 (1967).

${ }^{8 s}$ During the House Hearings, Assistant Attorney General Rosenberg argued against perpetuation of the standard under which the councils had been operating on the ground that it was not broad enough to reach conduct that ought properly to be within the powers of the councils to regulate. See House Hearings, supra note 24 , at $163-64,169-70,176$. In so doing, he neglected to note the broad interpretation that had been given to that language by the Conference in 1961 and again in 1974. See supra note 37. The differences in the language of the Act, compare 28 U.S.C. \$ 332(d)(1) (Supp. V 1981) ("all necessary and appropriate orders for the effective and expeditious administration of justice within its circuit") with id. at $\S 372(c)(1)$ ("conduct prejudicial to the effective and expeditious administration of the business of the courts") are evidence that Congress adverted to the judiciary's gloss and regarded the formulations as fungible. See HOUSE REPORT, supra note 14, at 9; 126 CONG. REC. S13,859, S13,860 (daily ed. Sept. 30, 1980) (statement of Sen. DeConcini).

st See supra notes 50 \& 52; see also Senate Hearings, supra note 24, at 58 (statements of Chief Judge Browning).

ss In eschewing detailed elaboration of the standard, the House report did not provide much guidance on its interpretation. The standard is said clearly to incorporate "complaints regarding impeachable behavior [and] violations of the criminal laws of any State or the United States." HOUSE REPORT, supra note 14, at 10. Assuming such complaints have merit, those alleging impeachable behavior will end up in the House. See 28 U.S.C. $\S \S 372(c)(7)(B) \&(c)(8)$ (Supp. V 1981). Indeed, the potential of council investigations to "reduce the impeachment burden upon Congress" through the development of a record or the inducement of voluntary action was cited as a reason to enact legislation in the area. House Hearings, supra note 24, at 89 (statement of Chief Judge Browning); see also 126 CONG. REC. 13,865 (daily ed. Sept. 30, 1980) (statement of Sen. Thurmond). Action on complaints alleging criminal behavior is likely to be deferred pending investigation by federal law enforcement authorities. See, e.g., House Hearings, supra note 24, at 88, 105 (statements of Chief Judge Browning). As to both, see Neisser, supra note 3, at 151-52. In the vast gray area, see supra text accompanying notes $75-81$, the House report suggests that the judiciary, although winning a number of battles concerning the standard for judicial discipline, lost the war. But see Neisser, supra note 3, at 152. In explaining the Act's provision for discretionary referral of a complaint by a judicial council to the Judicial Conference, see 28 U.S.C. $\S 372(c)(7)(A)$ (Supp. V 1981), the House report observes: "Likewise, it could involve an allegation that several judges have engaged in activities demeaning to the bench; assume, for example, that after a meeting of a circuit's judicial conference, a large number of judges become intoxicated in a bar of ill repute." HOUSE REPORT, supra note 14, at 12 .

On the other hand, the House responded to criticism concerning the absence of enumerated sanctions in existing legislation and in most of the councils' post-March 1979 rules. See House Hearings, supra note 24, at 161-62, 164-65 (statement of Assistant Attorney General Rosenberg). The House added to H.R. 6330 a list of sanctions drawn from S. 1873, which in turn appears to have been influenced in this aspect by the Bayh and Kennedy bills. See supra note 44; see also HOUSE REPORT, supra note 14 , at 6 . The authorized sanctions are contained in 28 U.S.C. $\S 372(c)(6)$ (Supp. V 1981), quoted supra note 7. Finally, Senator DeConcini hoped that, in exercising its power to review matters on petition by the complainant or the subject of a complaint, the Judicial Conference or a standing committee thereof "while not an independent review court, will provide for uniformity of decisions and the building of precedents." 126 CONG. REC. S13,858 


\section{Procedural Particularity}

The organization, jurisdiction, and powers of, and the substantive standards to be observed by, the recipients of delegated legislative power are the recognized province of Congress. It has been unusual, however, for Congress to concern itself with - although it has the power to prescribe - the details of procedure for implementing tasks delegated to the judiciary. ${ }^{88}$

The public record of council actions prior to the introduction of the Nunn/DeConcini bill evoked skepticism not only about the adequacy of existing statutory authority but also about the fairness with which asserted authority had been exercised. In two widely cited cases, it appeared that councils had acted without providing notice to the person affected and without affording him an opportunity to be heard. ${ }^{87}$ Thus, the federal judiciary's claim that informality and collegiality in handling complaints of misconduct or disability augured the best results consistent with judicial independence was tempered by concern that,.in the past, informality had produced unfairness and in fact imperiled the independence of individual federal judges.

When it became clear that a greater measure of formality in disciplinary procedures was expected, one matter that received attention from virtually all of the councils was the provision of procedural pro-

(daily ed. Sept. 30, 1980); see also id. at S13,860-61 (statement of Sen. DeConcini); id. at H10,191 (daily ed. Oct. 1, 1980) (statement of Rep. Kastenmeier). The provision in question, as amended by the Senate, is contained in 28 U.S.C. $\$ 372(c)(10)$ (Supp. V 1981), quoted supra note 9.

so In the case of supervisory court rulemaking, the pattern for many years was for Gongress to grant general authority to the Supreme Court to promulgate rules of procedure, reserving the right to review any such rules before they become effective. See, e.g., 28 U.S.C. § 2072 (1976). The rulemakers strenuously and successfully resisted legislative modification of or additions to court rules, fearing any derogation from the principle of institutional competence, and the reality of institutional power, for which members of the bar and the federal judiciary had struggled so long. See Burbank, The Rules Enabling Act of 1934, 130 U. PA. L. REv. 1015, 1178-79 (1982); cf. id. at 1153-54 n.601 (submission of amendments); letter from William D. Mitchell to the Hon. Warren Olney, Jr. (Jan. 15, 1938) (Charles E. Clark Papers, Yale University Library, box 111, folder 39) (congressional approval).

By 1980 Congress had broken the pattern and ceased routinely to acquiesce in supervisory court rules. See Burbank, supra, at 1018-20; see also 28 U.S.C. § 2076 (1976). Although that general change in Congress's attitude towards rulemaking by the judiciary should be acknowledged, the Act's procedural particularity is much more clearly the result of concerns and considerations specific to judicial misconduct and disability legislation and of the process by which it was formulated. In any event, court rulemaking, whether supervisory or local, may not be the most appropriate model for comparison. Congress has, of course, circumscribed the procedural discretion of administrative agencies. See, e.g., Administrative Procedure Act $\S \S 5-8,5$ U.S.C. $\$ \S 554-$ 57 (1976).

${ }^{87}$ See Chandler v. Judicial Council of the Tenth Gircuit, 398 U.S. 74 (1970); In re Imperial "400" National, Inc., 481 F.2d 41 (3d Cir.), cert. denied, 414 U.S. 880 (1973); see also Tydings, supra note 24 , at $322-23$; Wallace, supra note 24 , at $315-22$. 
tections for the subject of a complaint. ${ }^{88}$ Thereafter, the Judicial Conference approved a bill that contained most of the procedural requirements found in the Act, including various notice provisions and the requirement that council rules afford procedural rights to the subject of a complaint. ${ }^{80}$ It is interesting to observe the federal judiciary, which traditionally has resisted legislative attempts to circumscribe its freedom in rulemaking, ${ }^{90}$ proposing such restrictions. ${ }^{91}$ One senses the duality of judicial independence: the institution sought to be protected from, and the individual by, Congress.

In the end, Congress, resisting pressure to enact or require comprehensive uniform rules of procedure, ${ }^{92}$ accepted the argument that initial experimentation by the judicial councils of the circuits would yield better results. ${ }^{98}$ But Congress was unwilling to furnish the councils with a blank check.

In suggesting an "inquisitorial-administrative" model for the conduct of investigations, ${ }^{94}$ the House report responded to formal and philosophical distinctions that had been urged in support of the existing structure and to the concern that an "accusatorial-adversary" model would undermine judicial independence. ${ }^{95}$ In adopting the Conference's requirement that council rules afford certain basic procedural rights to the subject of a complaint, the House report revealed the elusiveness of

s8 Thus, although criticizing the councils' post-March 1979 rules, Assistant Attorney General Rosenberg observed that "virtually all of the circuits authorize procedures to ensure due process for an accused judge." House Hearings, supra note 24, at 166.

In its 1974 statement of "Powers, Functions and Duties of Circuit Councils," see supra note 37, the Conference had opined:

6. Before any action is taken with respect to a particular judge or other person attached to the courts in the circuit, that judge or other person should be invited to present his views to the council after being advised of the nature of the action which may be taken together with the reasons. Monitoring the substance of judicial decisions is not a function of the judicial council.

Report of the Proceedings of the Judicial Conference of the United States 8 (Mar. 1979).

${ }^{80}$ See H.R. 6330. For the origins of this bill, see supra note 59.

Do See supra note 86.

91 Some of the procedural requirements in H.R. 6330 can perhaps be laid to perceived constitutional necessity, but their very statement suggests, and the history confirms, see supra text accompanying note 87, that the perception had not been universal. In addition, H.R. 6330 lacked provisions for review of council rules and supervisory rulemaking by the Conference, with the result that its authors may have felt, or anticipated that Congress would feel, the need for some control of local rulemaking.

${ }^{22}$ See, e.g., House Hearings, supra note 24, at 189 (resolution of American Judicature Society Executive Committee); letter from Herbert H. Anderson to Rep. Robert W. Kastenmeier (May 22, 1980), reprinted in House Hearings, supra note 24, at 204; AJS Supports Discipline Bill But Urges Congress to Strengthen It, JUDICIAL CONDUCT REPORTER, Winter 1980, at 1.

os See SENATE REPORT, supra note 60, at 2, 10-11; HOUSE REPORT, supra note 14, at 13; see also House Hearings, supra note 24, at 101, 174. 117.

94 See HOUSE REPORT, supra note 14, at 14, quoted in part infra text accompanying note

9s See supra text accompanying notes $70-74$; note 82 . 
some of those distinctions and the variousness of judicial independence ${ }^{96}$ Moreover, the House added to H.R. 6330 provisions authorizing the Judicial Conference to modify any rule promulgated by a judicial council and to prescribe rules. ${ }^{97}$ Congress had, as we have seen, ample evidence that not all the councils were responsive to invitations to experiment and that experimentation could lead to disuniformity harmful to the goals of the legislation. ${ }^{98}$ The structure Congress finally approved suggested the Conference as the natural body to monitor local rulemaking and to ensure whatever uniformity, in addition to that required by the statute, was appropriate.

Consistently with its view that the House bill lacked adequate balance and thus did not go far enough to ensure public accountability, the Senate added, and the House endorsed, a provision requiring some procedural protection for the complainant in council rules. ${ }^{99}$

\section{Oversight}

Congress was not content to draw procedural boundaries and leave to the Judicial Conference the task of reconciling or completing the pictures drawn by the judicial councils. The Senate's insistent concern about public accountability - after the smoke had cleared, the major goal of the legislation - yielded more than enhanced procedural pro-

os Nonetheless, the potential excesses of a circuit council must be controlled. As a consequence, paragraph (c)(11) requires that minimal due process rights be accorded any judicial officer whose actions or state of health are being investigated by a circuit council. The net effect of this paragraph is that the possibility of one group of federal judges arbitrarily "ganging up" [sic] or "hazing" another judge is prevented.

HOUSE REPORT, supra note 14, at 14 (footnote omitted).

7 See H.R. 7974, supra note 1 (proposing amendments adding $\S 372(c)(11)$ and amending $\S 331$ ). These provisions, as reflected in the Act, are quoted supra note 11. For other procedural protections, taken from H.R. 6330, see supra text accompanying note 89 .

os For this reason alone, although it might be argued that the Conference's powers are limited to reconciling disuniformities in the local rules of the councils and prescribing rules for the conduct of its own business under the Act, that interpretation seems too narrow. See 126 CoNG. REC. S13,861 (daily ed. Sept. 30, 1980) (statement of Sen. DeConcini); id. at H10,191 (daily ed. Oct. 1, 1980) (statement of Rep. Kastenmeier). Compare HOUSE REPORT, supra note 14, at 13-14 with id. at 15-16. S. 1873 had authorized the Judicial Conference either to promulgate rules for the councils or to authorize the councils to promulgate their own rules. The bill also gave the Conference the power to modify any rule.

Withal, a clarification of the Conference's powers is desirable. See also infra text accompanying note 281 .

" See 126 CONG. REC. S13,860-61 (daily ed. Sept. 30, 1980) (statement of Sen. DeConcini); id. at H10,190-91 (daily ed. Oct. 1, 1980) (statement of Rep. Kastenmeier). The provision added by the Senate can be found in 28 U.S.C. \& 372(c)(11)(C) (Supp. V 1981), quoted supra note 11. For other Senate amendments designed "to preserve equal treatment between the parties in the process," see 126 CONG. REC. S13,860 (daily ed. Sept. 30,1980) (statement of Sen. DeConcini); id. at H10,191 (daily ed. Oct. 1, 1980) (statement of Rep. Kastenmeier). The Senate's amendments can be found in 28 U.S.C. $\$ 372(c)(10)$ (Supp. V 1981), quoted supra note 9. 
tection for the complainant. Congress had been urged to accept judicial self-regulation as an experiment that could be replaced if the results were unsatisfactory, ${ }^{100}$ but it had also been urged by others to follow the experiment closely. ${ }^{101}$ The House bill added to H.R. 6330 a requirement of reports to Congress. ${ }^{102}$ The Senate attempted to make the process of resolving complaints less impenetrable by highlighting the distinction between confidentiality and privilege $e^{103}$ and by requiring that written orders issued by the councils and the Conference be made publicly available and, in most cases, include a statement of reasons. ${ }^{104}$ The Senate's amendments were accepted, ${ }^{105}$ and the obviously coordinated statements of the managers of the legislation suggested a determination to ensure public accountability through legislative oversight. ${ }^{108}$

100 See, e.g., Hearings on $S .677$ and S. 678, supra note 50, at 5 (statement of Chief Judge Coffin); Senate Hearings, supra note 24, at 60 (statement of Judge Wallace).

101 See, e.g., Senate Hearings, supra note 24, at 7 (joint statement of Clark Mollenhoff and Greg Rushford); House Hearings, supra note 24, at 121 (joint statement of Clark Mollenhoff and Greg Rushford).

${ }_{102}$ See H.R. 7974, supra note 1 (proposing amendment adding $\S 604(\mathrm{~h})(2)$ ). S. 1873 had contained a similar provision. As enacted, the requirement appears in 28 U.S.C. $\S 604(\mathrm{~h})(2)$ (Supp. V 1981). See also infra text accompanying notes 259-270.

${ }_{103}$ See 126 CONG. REC. S13,861 (daily ed. Sept. 30, 1980) (statement of Sen. DeConcini); id. at $\mathrm{H10,191}$ (daily ed. Oct. 1, 1980) (statement of Rep. Kastenmeier). As revised to delete any reference to privilege, the Act's confidentiality provision states:

(c)(14) All papers, documents, and records of proceedings related to investigations conducted under this subsection shall be confidential and shall not be disclosed by any person in any proceeding unless -

(A) the judicial council of the circuit, the Judicial Conference of the United States, or the Senate or the House of Representatives by resolution, releases any such material which is believed necessary to an impeachment investigation or trial of a judge under article I of the Constitution; or

(B) authorized in writing by the judge or magistrate who is the subject to [sic] the complaint and by the chief judge of the circuit, the Chief Justice, or the chairman of the standing committee established under section 331 of this title.

28 U.S.C. § 372(c)(14) (Supp. V 1981).

1o4 See 126 CONG. REC. S13,861 (daily ed. Sept. 30, 1980) (statement of Sen. DeConcini); id. at H10,191 (daily ed. Oct. 1, 1980) (statement of Rep. Kastenmeier). 28 U.S.C. § 372(c)(15) (Supp. V 1981) provides:

(c)(15) Each written order to implement any action under paragraph (6)(B) of this subsection, which is issued by a judicial council, the Judicial Conference, or the standing committee established under section 331 of this title, shall be made available to the public through the appropriate clerk's office of the court of appeals for the circuit. Unless contrary to the interests of justice, each such order issued under this paragraph shall be accompanied by written reasons therefor.

${ }^{108}$ See 126 CONG. REC. H10,192 (daily ed. Oct. 1, 1980).

100 Compare 126 CONG. REC. S13,861 (daily ed. Sept. 30, 1980) (statement of Sen. DeConcini) with id. at H10,191 (daily ed. Oct. 1, 1980) (statement of Rep. Kastenmeier). Both statements include, with slight variation, the following:

In addition to those four substantive changes included in the Senate amendment, both the House and Senate Judiciary Committees believe that there should be a continuing dialog between the legislative and judicial branches, and vigorous oversight by Congress. Section 5 of the proposal requires that the Director of the Administrative Office of the United States Courts shall include in his annual report 


\section{RULEMAKING UNDER THE ACT}

Neither judges nor those who write about their work product have shown much interest in the jurisprudence of federal court rulemaking. ${ }^{107}$ As a result, we lack an accepted framework within which to evaluate prospective procedural rules. Moreover, because attention in federal court rulemaking has fastened almost exclusively on national rules, our impoverishment is particularly acute with respect to local rulemaking. ${ }^{108}$ To a great extent, therefore, a critique of council rulemaking under the Act must proceed from normative premises as to which there is no consensus. Unless, however, rulemakers can be brought to an articulated, or at least articulable, position on such issues as level of detail, uniformity, and rulemaking power, we are doomed to a regime characterized by ad hoc justification on the one hand and ad hoc repudiation on the other. Discretion is, of course, an instrument of power. Those who would embrace it are well advised to consider where ultimate power lies and to be alert to the risks of its exercise.

\section{A. Minimalism}

There can be little doubt that Congress expected the councils to accept the Act's invitation to promulgate rules. Influences shaping that expectation included the Judicial Conference's March 1979 resolution and the practical political considerations that animated it, dissatisfaction with the rules of the councils promulgated pursuant to that resolution, and the overwhelming trend of the judiciary, since 1934, to make procedural law by prospective rules. ${ }^{100}$ Indeed, Congress accepted local

filed with the Congress a summary of the number of complaints filed with each judicial council under section 372(c) of title 28, United States Code, indicating their general nature and the disposition of those upon which action has been taken.

In order to better perform its oversight responsibilities, the committee will give serious consideration to making requests for other reports on the implementation of the act, as well as possible oversight hearings and subsequent perfecting amendments to the statute.

107 But see, e.g., Burbank, Sanctions in the Proposed Amendments to the Federal Rules of Civil Procedure: Some Questions About Power, 11 HoFSTRA L. REV. 997 (1983); Clark, Special Problems in Drafting and Interpreting Procedural Codes and Rules, 3 VAND. L. REV. 493 (1950).

Questions of supervisory court rulemaking process and structure in the federal system have, however, received considerable attention. See, e.g., W. BROWN, FEDERAL RULEMAKING: PROBLEMS AND POSSIBILITIES (1981); J. WEINSTEIN, REFORM OF COURT RULE-MAKING PROCEDURES 21-115 (1977); Burbank, supra, at 998 n.2. Moreover, there is an analogically useful literature in administrative law. Sec, e.g., $2 \mathrm{~K}$. DAVIS, ADMINISTRATIVE LAW TREATISE chs. 7, 8, 10 (2d ed. 1979); see also Burbank, supra note 86, at 1193-94.

108 But see, e.g., J. WEINSTEIN, supra note 107, at 117-45; Flanders, Local Rules in Federal District Courts: Usurpation, Legislation, or Information?, 14 LOY. L.A.L. REV. 213 (1981); see also Burbank, supra note 107, at 998 n.2.

100 In addition to the considerations mentioned in the text, it should be noted that the Act 
rulemaking on the theory that, at least initially, the benefits of experimentation would outweigh its costs. ${ }^{110}$ The benefits were, however, speculative, and there was evidence of the costs. ${ }^{111}$ In prescribing uniform procedure for some of the "important issues" as to which silence or dissonance might have had a serious adverse effect on the achievement of the Act's purposes, and in providing the Judicial Conference with powers of review and initiation, Congress sought to guide and circumscribe elaborative local rulemaking, not to stifle it. ${ }^{112}$

Since all of the councils have rules in place, ${ }^{\mathbf{1 1 3}}$ apparently they have heard Congress's message. But have they? Most of the councils have chosen not to elaborate in any detail the process and skeletal procedure set forth in the Act. ${ }^{114}$ Some of the councils' rules even fail to treat matters that were dealt with in those councils' pre-Act rules. ${ }^{115}$ Much of what little is new in the councils' rules addresses matters of minor significance; and some of what is new is of questionable valid-

does require the specialized courts to promulgate rules. See supra note 19. The reason for the disparate treatment appears to lie in the origins of the respective rulemaking provisions. H.R. 6330 , supra note 59 , the Judicial Conference's bill, included a provision authorizing (but not requiring) the councils to promulgate rules. The House modified that provision by empowering the Judicial Conference to modify council rules and itself to prescribe rules. See supra text accompanying note 97 . All of the provisions respecting the specialized courts were added by the House. Compare H.R. 6330 with H.R. 7974, supra note 1.

In addition, the expectation that the Judicial Conference would exercise its rulemaking power is explicit in the Act's legislative history. See 126 CONG. REC. S13,861 (daily ed. Sept. 30, 1980) (statement of Sen. DeConcini); id. at H10,191 (daily ed. Oct. 1, 1980) (statement of Rep. Kastenmeier). Thus far, the Conference has not done so. See infra note 196. Finally, the concerns that led Congress to require procedural protections for the subject of a complaint and the complainant in council rules, see supra text accompanying notes $87,94-96 \& 99$, seemingly render academic the question whether a council that did not promulgate prospective rules could proceed without affording such protections. If so, that perception tends to confirm that Congress expected the councils to promulgate rules.

110 See supra text accompanying note 93.

11 See supra text accompanying notes 61-62 \& 98. Criticism of council rules was based in part on perceived "glaring disparities between circuits, both with regard to the specific procedures they establish[ed] and the elements of process they cover[ed]." HOUSE REPORT, supra note 14, at 4 (footnote omitted). It was, however, also based in part on the perception that council rules, "in many instances, [were] silent on important issues." 126 CONG. REC. S13,859 (daily ed. Sept. 30, 1980) (statement of Sen. DeConcini).

112 See HOUSE REPORT, supra note 14, at 13-14; see also 126 CONG. REC. S13,859 (daily ed. Sept. 30, 1980) (statement of Sen. DeConcini) ("[The Act] would, I believe, go a long way toward remedying the existing deficiencies in the various sets of rules now in use by the 11 judicial councils by strengthening and clarifying their power to handle complaints against members of the Federal judiciary.").

113 See supra text accompanying note 18.

116 See the analytical table, infra Appendix A.

${ }^{116}$ For instance, pre-Act Rule E(1) of the Judicial Council of the D.C. Circuit gave to the authorized screening authorities "full discretion as to whether the identity of a complainant shall be disclosed to the judge complained of if a complaint is dismissed." House Hearings, supra note 24 , at 455 . The question is not addressed in that council's rules promulgated to implement the Act. The same council provided guidance on the rules of evidence in its pre-Act rules, id. at 453, but does not do so in the post-Act rules. See also infra note 188. 
ity. ${ }^{116}$ With few exceptions, the councils have declined to answer the most important procedural questions raised by the Act, including how a special committee appointed by a chief judge will conduct its investigation, how a judicial council will proceed after receipt of the report of a special committee, and how a council will handle petitions for review.

\section{The Benefits of Rulemaking Minimalism}

There are reasons, including some good reasons, for the choice that most councils have made not to elaborate in detail the statutory procedure.

\section{a. Avoidance of Inappropriate Procedural Choices}

First of all, it bears stating that the legislation creates much more of an "inquisitorial-administrative" model than an "accusatorial-adversary" one. In this regard, the judicial council is not to be thought of as a passive and impartial referee; rather, the council can become the active gatherer of evidence and can control the objectives and nature of the inquiry. ${ }^{117}$

The Act contemplates or will accommodate modes of proceeding that are unfamiliar to the American bench and bar. As a result, the councils had reason to fear that prospective rules might yield inappropriate procedural choices and reason to desire experience before undertaking generalized lawmaking. ${ }^{118}$ After all, the greatest procedural reform in this century, the Federal Rules of Givil Procedure, however inspired, was in good measure a collection of legal transplants. ${ }^{119}$

\section{b. Flexibility and Informality}

Formalism itself may have seemed a threat, either because the choices it might impose could undermine collegial, non-adversary resolution of complaints or because it could highlight the Act's fragile

116 See infra text accompanying notes 197-242.

117 HOUSE REPORT, supra note 14, at 14 (footnote omitted). In the footnote, the report states: "The 'inquisitorial' type procedure has worked well in many of the European court systems and there is little reason to doubt its adaptability to the proposed legislation." Id. at n.33. See also id. at 4 .

118 Cf. Washington-Southern Navigation Co. v. Baltimore \& Philadelphia Steamboat Co., 263 U.S. 629, 635 (1924) ("Most [court] rules are merely a formulation of the previous practice of the courts.").

110 See Burbank, supra note 86, at 1168 \& n.657. 
compromises. ${ }^{120}$

\section{c. Conserving Scarce Resources}

The choice not to elaborate statutory process and procedure may have seemed attractive at the time for other reasons. It permitted the development and promulgation of rules without a great investment of time by overburdened federal judges and administrative staffs, and assured that rules would be in place when the Act became effective. ${ }^{121}$

\section{d. Familiarity}

Finally, in fashioning statutory process and procedure, Congress drew primarily on legislative proposals that in turn reflected models created by judges who were justifiably proud of their work. ${ }^{122}$ For councils already operating under such models, there was no incentive to do more than make minor adjustments. They thought the models satisfactory, and Congress had been so informed. ${ }^{123}$

\section{The Costs of Rulemaking Minimalism}

Such seem to be the reasons supporting, and the potential benefits of, the choice of most councils closely to adhere to the procedural skeleton provided by Congress. It remains to consider the case against that approach.

130 See supra text accompanying notes 35, 70-74; note 57; cf. Second Circuit Rule 0.24(j) ("The adoption of this rule shall not be construed as indicating any views with respect to the constitutionality of Title 28 U.S.C. § 372 (c) or of any action taken thereunder"). Of course, elaborative rulemaking need not enshrine inflexible or adversary procedure. See infra text accompanying notes $173-74,177-79 \& 194-95$.

${ }^{121}$ A questionnaire prepared by the author was sent to all circuit executives, and responses were received from all circuits. The responses to a question inquiring "Who had the responsibility to prepare the initial draft of rules in your circuit?" yield the following: Circuit Executive or Assistant Circuit Executive 4; Circuit Executive and Council Subcommittee 1; Staff Attorney 1; Reporters 1; Court Proctor for Rules (a federal judge) and clerk of court 1; Council Subcommittee 2; Circuit Judge 1; Chief Judge 1. The responses are on file with the University of Pennsylvania Law Review. The identities of the respondents are held confidential.

For an argument that the councils' approach may prove inefficient over the long term, see infra text accompanying note 175 .

${ }^{192}$ As noted supra text accompanying note 66, the basic model used by Congress was H.R. 6330 , supra note 59, the Judicial Conference's bill. That bill was, in turn, informed by rules adopted by the Ninth Circuit Council, and subsequently by the Tenth Circuit Council, in late 1978 and by the Judicial Conference's March 1979 resolution. See House Hearings, supra note 24, at 63 (statement of Judge Hunter); WHEELER \& LEVIN, supra note 30, at 48; Browning, supra note 3, at 203; letter from Hon. Elmo B. Hunter to all Senators, supra note 52.

${ }_{113}$ See House Hearings, supra note 24, at 63 (statement of Judge Hunter); Browning, supra note 3, at 203-04; see also letter from Hon. Elmo B. Hunter to all Senators, supra note 52 . The Judicial Council of the Tenth Circuit did not make even minor revisions in response either to the March 1979 Judicial Conference resolution or to the Act. See supra text accompanying note 18. 


\section{a. Procedural Innovation Forgone}

The slight elaboration of the Act's procedure in most councils' rules has failed to yield the benefits of decentralized experimentation the prospect of which was the main justification for reposing rulemaking authority in the councils in the first instance. ${ }^{124}$ The councils did borrow in developing their rules. Apart from the statute, however, the only models of obvious relevance ${ }^{\mathbf{1 2 5}}$ available were the sets of rules that first appeared after the Act was passed. Those rules did not significantly elaborate the Act's provisions. ${ }^{126}$ In this case, borrowing impeded procedural innovation. ${ }^{127}$

\section{b. Public Accountability and Judicial Independence Disserved}

More important, the councils' approach entails significant costs to the congressional goals of public accountability and judicial independence. It would seem that the remaining "important issues"128 to be addressed in council rules are to be found precisely where silence has that effect.

\section{(i) General Considerations}

The extent to which prospective procedural rules should attempt to anticipate and resolve problems likely to arise in the administration of the substantive law is a question inherent in the rulemaking enterprise. The need for certainty and predictability in the administration of the substantive law must be balanced against the potential consequences of inappropriate procedural choices. ${ }^{129}$ In assessing the former, the

124 See supra text accompanying note 93 .

125 State models seem not generally to have been considered. See supra note 82 . But see Third Circuit Rule 6(D)(iv) reporters' note.

128 The first rules to appear were those of the Judicial Council of the Sixth Circuit, adopted on February 10, 1981, which do not elaborate, and indeed fail to incorporate some of, the Act's provisions. Conversations with those involved in drafting the rules for the District of Columbia and the Eighth Circuit Councils, the next rules to appear, and for the First Circuit Council, confirm that the Sixth Circuit Rules were used as a model. See also the analytical table, infra Appendix A. For problems arising from the use of this model, see infra notes 148-153, 198 \& 200.

To assist the reader in identifying borrowing where it occurs, the councils' rules are cited in the order in which they were adopted.

${ }^{127}$ This is only surprising if one thinks of the role of legal transplants in legal development, see A. WATSON, LEGAL TRANSPLANTS (1974), without also considering the particular circumstances confronting the councils. See supra text accompanying notes 117-20.

128 See supra note 111.

129 Even as ardent an opponent of codification of the common law as James Coolidge Carter acknowledged that some matters "should properly be made the subject of statutory enactment." J. CARTER, THE PROPOSED CODIFICATION OF OUR COMMON LAW 16 (1884). With respect to court procedure, he stated: 
availability and adequacy of alternative sources of law to provide procedural direction should be considered. ${ }^{130}$ In assessing the latter, it is important to take into account the process by which rules found to reflect inappropriate choices can be amended. ${ }^{131}$

In the case of rulemaking under the Act, there were legitimate causes of concern. The unfamiliarity of the territory, the absence of elaborative models, and the perceived fragility of judicial independence suggested caution. But in failing to elaborate significant aspects of the statutory process, most of the councils appear to have given insufficient weight to the peculiar need for certainty and predictability in this context.

(ii) Chief Judge Action

The Act provides detailed guidance on the process for filing a complaint and on the powers of the chief judge in reviewing it. ${ }^{132}$ There is room for elaboration, to be sure, ${ }^{133}$ but rules that track the statutory sections provide a mechanism for initial screening that is predictable and comprehensible, prescribing the main elements of the process and channeling the chief judge's discretion. The major area of ambiguity types of conduct subject to disciplinary action - is substantive and lies beyond the councils' rulemaking power. ${ }^{134}$

\footnotetext{
It is important that this should be regulated by written rules framed beforehand; and yet the existence of such rules, if they have the rigidity of statutory law, becomes the fruitful source of mischief. Cases will continually arise not foreseen by the framers of the written rules, and consequently inadequately provided for. The true wisdom in relation to this subject is to deal with it in a way which affords the advantages of statutory law without its evils; and that is to entrust it to the courts to frame rules for its regulation.
}

Id. at 19 (emphasis in original); see id. at 84; see also Burbank, supra note 86, at 1044 n.124; Morgan, Foreword to MODEL CODE OF EvIDENCE at 12-13 (1942); cf. Powers, Formalism and Nonformalism in Choice of Law Methodology, 52 WASH. L. REV. 27 (1976) (analyzing various choice of law methodologies in terms of the respective values of formalism and nonformalism).

180 For the effect on the codification movement of the appearance of secondary sources, see Pound, David Dudley Field: An Appraisal, in DAVID DUDLEY FIELD: CENTENARY EssaYs 9 (A. Reppy ed. 1949).

1s1 See J. CARTER, supra note 129, at 19-20. In advocating a bill granting the Supreme Court of the United States the power to make supervisory court rules of procedure in civil actions at law, supporters emphasized speed of amendment as an advantage of such a system over legislative control of procedure. See Burbank, supra note 86, at 1077 n.268, 1162 n.632. That goal was frustrated by changes in the bill requiring reporting to Congress. See id. at 1077 n.268, 1153-54 n.601, 1162 n.632.

1ss See 28 U.S.C. $\S 372(c)(1)$ (Supp. V 1981), quoted supra note 4; id. $\$ \S 372(c)(2)-(3)$, quoted supra note 5 .

13s See, e.g., the analytical table, infra Appendix A.

196 See supra text accompanying notes 75-85. "[R]ules for the conduct of proceedings under this subsection," 28 U.S.C. $\$ 372$ (c)(11) (Supp. V 1981), quoted supra note 11, does not include rules elaborating the Act's standards of misconduct or disability. See also infra text accompanying notes 226-30. 
(iii) Special Committee Procedure

It is at the point when a chief judge has not been able to dismiss or close a complaint - when both public accountability and judicial independence not only appear to be but are concerns - that the Act ceases to provide clear guidance. After a special committee has been appointed by, and received a copy of the complaint and related documents from, the chief judge, ${ }^{138}$ the Act directs it to "conduct an investigation as extensive as it considers necessary."136 Expecting that the councils would revise their rules in response to the Act, Congress required that those rules include provisions for written notice of an investigation to the subject of a complaint and for certain procedural rights of both the subject of a complaint and the complainant. ${ }^{137}$ That is what, and in most cases all that, the councils' rules do in prescribing special committee procedure. ${ }^{138}$

Even with the encouragement of the House report, it is not surprising that the councils did not rush to the codes of Civilians, or even to the procedural rules of administrative agencies, for guidance in formulating the procedure to be followed by special committees. ${ }^{139}$ Here is where the desire to gain experience before enshrining a particular mode is most understandable. But here also the claims of those involved and of the public to certainty and predictability are particularly insistent.

Given the weight likely to be assigned to a special committee's report by the judicial council, ${ }^{140}$ complainants and the public have reason to fear that, if there is to be a "whitewash,"141 it will occur in - and may be impossible to expose after — an investigation by a special com-

128 See 28 U.S.C. § 372(c)(4) (Supp. V 1981), quoted supra note 6.

13628 U.S.C. § 372(c)(5) (Supp. V 1981), quoted supra note 6.

137 See supra note 11; text accompanying notes 97-98 \& 109.

188 See the analytical table, infra Appendix A.

198 See supra note 117 and accompanying text. For a more cynical view than that taken in the text, see infra text accompanying note 177. Cf. $3 \mathrm{~K}$. DAVIS, supra note 107, $\S 16: 1$, at 224: "The reason the three study groups [the American Law Institute, the Commissioners on Uniform State Laws, and the Advisory Committee on Federal Rules of Evidence] failed to study the agency system [of evidence] is not that their members were familiar with it and rejected it on its merits; the reason is that they were unfamiliar with it."

1s0 See Third Circuit Rule 7(F), which provides in pertinent part: "In deciding what action to take in a matter presented to it under this Rule, the Judicial Council shall accord substantial weight to the findings and recommendations of the Special Committee." The draft of the Second Circuit Rule submitted for public comment would have required a three-quarters majority of the Council to reject a special committee's recommendations. See $2 d$ Circuit to Revise Rules for Complaints Against Judges, N.Y.L.J., July 28, 1981, at 2, col. 4. It was deleted, and no other council's rules address the matter. But the central position of special committees within the scheme of the Act and considerations of efficiency both point towards considerable deference by the council. See also Neisser, supra note 3 , at 157.

14 SENATE REPORT, supra note 60, at 3; see also House Hearings, supra note 24, at 164 (statement of Assistant Attorney General Rosenberg). 
mittee. ${ }^{142}$ It probably is not a just criticism of council rules that they fail to afford complainants a greater role in special committee investigations than is required by the Act. ${ }^{143}$ However, in enumerating only statutorily required rights, which emphasize the protection of the subject of a complaint, most of the councils' rules do nothing to assure the public that special committee investigations will be orderly, thorough,

112 But see infra text accompanying notes 161-70 concerning the potential for abuse presented by the Act's provisions for dismissal of a complaint, in light of the ambiguity of the substantive standards, the unavailability of orders of dismissal for public scrutiny, and the finality of council action on petitions for review.

143 In explaining the provision that, after amendment by the Senate, became 28 U.S.C. $\S 372(c)(11)$ (Supp. V 1981), quoted supra note 11, the House report emphasized that, notwithstanding the mandatory procedural protections required in council rules, the paragraph:

should not be read to mandate the utilization of adversary procedures by the judicial councils or the Judicial Conference. It clearly is not the intent of the legislation to place an individual judge or magistrate in the position of being a defendant in an adversary proceeding before a panel of his or her colleagues.

Thus, although the legislation does not inflexibly preclude this in all cases, there is no statutory requirement that the complainant be granted all the same rights as the accused judicial officer. Thus, for example, the legislation does not provide the complainant with a hearing of right, or for the opportunity to crossexamine witnesses.

HOUSE REPORT, supra note 14, at 14. The report went on to defend "[t]his imbalance of rights" against a charge of unfairness by distinguishing between "inquisitorial-administrative" and "accusatorial-adversary" models. Id.; see supra text accompanying note 117. A Senate amendment added $\S 372(c)(11)(\mathrm{C})$. See supra text accompanying note 99.

Only the Third Circuit Judicial Gouncil has elaborated the statute in this aspect. Third Circuit Rule 6(B)(ii) provides:

\section{(B) Notice and Opportunity to Appear or Present Argument.}

...

(ii) Complainant. During the Special Committee's investigation, the complainant shall be afforded an opportunity to present argument in writing. The complainant shall also be afforded an opportunity to appear at proceedings conducted by the Special Committee, and to exercise one or more of the rights conferred by Rules 6(B)(i) and 6(C), if the Special Committee concludes that the complainant could thereby offer substantial additional information or assistance. In such event, the Special Committee may, if the circumstances so require, allow the complainant to be accompanied by counsel.

The reporters' note explains:

Rule 6(B)(ii) tracks and expands upon 28 U.S.C. $\$ 372(c)(11)(C)$. The complainant has not been given an absolute right to appear, because it is doubtful that such a right would be consistent with the Act (see 126 Cong. Rec. S13861 (daily ed. Sept. 30, 1980) and id. H10191 (daily ed. Oct. 1, 1980), and because it is not deemed necessary to protect the interests of the complainant or of the system of justice. If the Special Committee decides that the complainant should be permitted to appear, it should also have discretion to permit the complainant to exercise any of the rights enumerated in Rules 6(B)(i) and 6(C). Where the Special Committee decides that an appearance by the complainant would not contribute "substantial additional information," the opportunity to present argument in writing may be perceived, at least by those unfamiliar with the "inquisitorial-administrative" model, as an important means of ensuring that the Special Committee has and considers all relevant information. The provision regarding counsel accompanying a complainant is taken from 126 Cong. Rec. S13861 (daily ed. Sept. 30, 1980).

Third Circuit Rule 6(B)(ii) reporters' note. 
and fair. ${ }^{144}$ Moreover, alternative sources do not currently provide such assurance. Complainants are likely to be excluded from most if not all aspects of a special committee's investigation. ${ }^{145}$ In most circuits, a committee's findings and recommendations apparently are confidential, and its report is not required to describe the committee's procedure. ${ }^{148}$ It is questionable whether council orders will meet the need, for although required to be publicly available, such orders will not typically be published. Even if the orders are published, and although required to include written reasons, they may not set out in any detail the procedure followed by special committees or the councils. Finally, the experience to date suggests that it may be a long time before there will be enough experience with special committee investigations to develop, let alone publicize, what might be called a common law procedure. ${ }^{147}$

To federal judges concerned about their independence, a special

144 But see President's Statement on Signing S. 1873 into Law, 16 WEEKLY COMP. PRES. Doc. 2239-40 (Oct. 15, 1980):

At the same time, the legislation creates uniform, known procedures for dealing with an unfit judge. Citizens can be confident that a complaint filed under this system will receive fair and serious attention throughout the process. For all these reasons the new process should increase public confidence in the quality of the Federal judiciary.

145 See supra note 143 and accompanying text.

166 The Act requires a special committee to file with the council "a comprehensive written report . . . present[ing] both the findings of the investigation and the committee's recommendations." 28 U.S.C. \$ 372(c)(5) (Supp. V 1981), quoted supra note 6. Unlike the written orders of a council acting on a special committee's report, the report itself need not be made available to the public. See id. § 372(c)(15), quoted supra note 104. Nor is there any requirement that a copy be furnished to the complainant or the subject of the complaint. Only the Third Circuit Judicial Council has so provided by rule. See Third Circuit Rule 6(F). The reporters' note explains:

Rule $6(F)$ is not required by the Act. It can be argued that, since the Special Committee simply advises the Judicial Council, transmittal is neither necessary nor appropriate. However, particularly in light of the provision in Rule 7(F) regarding the weight to be given the Special Committee's report, knowledge of the contents of the report would appear important to both the judge or magistrate whose conduct is the subject of the complaint and the complainant in determining whether to petition the Judicial Conference for review of an action of the Judicial Council. In addition, transmittal to the complainant may further the goal of accountability.

The Rule provides that the report will be transmitted subject to a confidentiality order pursuant to 28 U.S.C. \& 372(c)(14). See Rule 10(J). Copies of the report should be marked "Confidential."

Third Circuit Rule 6(F) reporters' note.

${ }^{167}$ For the statutory requirements regarding council orders, see supra note 104. The Judicial Council of the Ninth Circuit has published certain orders. See In re Charge of Judicial Misconduct, 685 F.2d 1226 (9th Cir. Judicial Council 1982) (review petition dismissed). For pre-Act published dispositions, all dismissals by the Chief Judge, see In re Charge of Judicial Misconduct, 613 F.2d 768 (9th Cir. 1980) (Browning, C.J.); In re Charge of Judicial Misconduct, 595 F.2d 517 (9th Cir. 1979) (Browning, C.J.); In re Charge of Judicial Misconduct, 593 F.2d 879 (9th Cir. 1979) (Browning, C.J.). For subsequent dispositions to be published, see In re Charge of Judicial Misconduct, No. 82-8114 (9th Cir. Oct. 29, 1982) (Wright, J.); In re Charge of Judicial Misconduct, No. 82-8059 (9th Cir. Judicial Council Nov. 1, 1982) (review petition dismissed).

For another means of dissemination of procedure, see infra text accompanying note 150 . For experience to date, see infra note 257. 
committee investigation is also a major focus of concern, which is why Congress, following the Conference's proposal, required that the subject of a complaint be afforded certain procedural rights at "proceedings conducted by" the committee. ${ }^{148}$ Those rights tend to assure that a special committee's findings and recommendations will not be arbitrary. The question is whether they go far enough and whether uncertainty in that regard well serves the policy of preserving judicial independence.

In most circuits, a judge or magistrate who is the subject of a complaint will not know how, if the complaint is referred to a special committee, the committee's investigation will proceed, whether and when access to any investigative file will be afforded, at what stage in the committee's investigation procedural rights may be exercised, the nature of "proceedings" conducted by the committee (including the order of proof, the rules of evidence, and the method of presenting and obtaining rulings on objections), whether a transcript of the "proceedings" will be available, or the information that may be considered by the committee in preparing its findings and recommendations for the judicial council. $^{148}$

In short, the subject of a complaint has no assurance that the exercise of procedural rights holds the promise of affecting the findings and recommendations of the special committee. Such information could be

168 See 28 U.S.C. § 372(c)(11)(B) (Supp. V 1981), quoted supra note 11; supra note 96 and accompanying text. The word "proceedings" as used in this section is not defined in the Act or its legislative history. Third Circuit Rule $1(\mathrm{E})$ defines the word as meaning "any meeting of a special committee . . . or of the Judicial Council at which record evidence is taken." Third Circuit Rule 1(E) reporters' note observes:

Rule $1(E)$ is also new. "Proceedings" is necessarily a narrower concept than "investigation" if an "inquisitorial-administrative" model of the sort contemplated by Congress is to be implemented. See H.R. Rep. 96-1313, 96th Cong., 2d Sess. 14 (1980). . . . As pointed out in the Note to Rule 6(B)(i), an investigation may go forward without the participation of the judge or magistrate whose conduct is the subject of a complaint. However, although the Judicial Council and any Special Committee have authority to conduct broad investigations (see 28 U.S.C. $\S \S 372(\mathrm{c})(5)$ and $(6)$ and Rules $6(\mathrm{~A})$ and $7(\mathrm{~A})$ ), under these Rules no dispositive action by either of those entities can be based on anything other than record evidence taken at "proceedings," and the judge or magistrate has procedural rights in connection with the taking of such evidence. See Rules $6(B)(i), 6(E), 7(C)(i)$ and 7(F).

The failure of some councils' rules to distinguish between "proceedings" and "investigation" leaves unclear whether under those rules a special committee has the option to file a report without conducting "proceedings," an interpretation evidently foreclosed by the legislative history, see HOUSE REPORT, supra note 14 , at 14, or whether the subject of a complaint can insist on exercising the procedural rights conferred at any stage of a special committee's investigation. The latter interpretation also seems inconsistent with the legislative history. See id.; supra note 120 and accompanying text. But see 28 U.S.C. § 372(c)(11) (Supp. V 1981), quoted supra note 11 (suggesting a broad interpretation of "proceedings"). For rules that present this problem, see, e.g., Sixth Circuit Rules 6 \& 10; Eighth Circuit Rules 5 \& 9; First Circuit Rules 7 \& 11. For the influence of borrowing, see supra note 126 .

140 See the analytical table, infra Appendix A. 
provided by memorandum at the start of an investigation. ${ }^{150}$ But to be disseminated, procedure must exist. In any event, whatever assurance an individual judge involved in the process receives from a memorandum is unlikely to benefit other judges in the circuit. That may be reason enough not to engage in conduct that could be made the subject of a colorable complaint, quite a chill when one recalls the Act's substantive ambiguity. ${ }^{151}$

\section{(iv) Judicial Council Procedure}

The Act has been widely interpreted to say even less about the procedure to be followed by a judicial council after receipt of the report of a special committee. A council is empowered to conduct "any additional investigation which it considers to be necessary,"162 and it must provide written notice of such an investigation to the subject of the complaint. ${ }^{16 s}$ Believing that they were under no other specific constraints, ${ }^{154}$ but concomitantly lacking any other statutory provisions to

130 One respondent to the author's questionnaire, supra note 121, observed that the answers to a number of questions of interpretation regarding that council's rules had not been reflected in amendments to those rules but rather in "changes in our own internal operating procedures." Moreover, it was said that "in those infrequent instances, where appropriate, judges or other persons involved in a proceeding will be informed of these procedures by memorandum." In a subsequent telephone conversation, this respondent observed that the advisability of amending the council's rules was under consideration.

181 See supra text accompanying notes 82-85; see also HOUSE REPORT, supra note 14, at 1819; 126 CONG. REC. S13,864 (daily ed. September 30, 1980) (statement of Sen. Mathias).

13228 U.S.C. \& 372(c)(6)(A) (Supp. V 1981), quoted supra note 7.

16328 U.S.C. \$ 372 (c)(11)(A) (Supp. V 1981) ("adequate prior notice of any investigation"), quoted supra note 11 . Failure to recognize the applicability of this requirement to council investigations is common among the councils' rules. See, e.g., Fifth Circuit Rule 24.2; see also Ninth Circuit Rules 5 \& 6; Third Circuit Rules 6 \& 7; Eleventh Circuit Rules 5 \& 6. Equally common is the failure to include in council rules any reference to the statutory requirement of notice of an investigation (that is, even in connection with a special committee investigation). See Sixth Circuit Rules 6 \& 8; D.C. Circuit Rules 5 \& 6; Eighth Circuit Rules 5 \& 7; First Circuit Rules 7 \& 9. It may be that, as applied to special committees, the requirement was deemed redundant in light of the Act's provision for written notice upon appointment of such a committee. Sec 28 U.S.C. § 372(c)(4)(C) (Supp. V 1981), quoted supra note 6; D.C. Circuit Rule 4(C); First Circuit Rule 7. But note that neither the Sixth Circuit nor the Eighth Circuit provides for such notice in its rules. See the analytical table, infra Appendix A. For the influence of borrowing, see supra note 126.

164 It should be noted, however, that the discussion of the "inquisitorial-administrative" model and of "the potential excesses of a circuit council" in HOUSE REPORT, supra note 14, at 14, quoted supra note 96 , is fully as applicable to council investigations as it is to special committee investigations. Cf. supra note 153 (notice of investigation required at both stages). Nonetheless, the rights enumerated in 28 U.S.C. $\$ \S 372$ (c)(11)(B) \& (C) (Supp. V 1981), have been thought by many to be mandatory only in connection with council rules governing special committee investigations. This presumably is why there is no relevant provision concerning council procedure in the rules of the Judicial Councils of the District of Columbia, Ninth, Seventh, and Eleventh Circuits. See the analytical table, infra Appendix A; see also Third Circuit Rule 7(C)(i) reporters' note. The strongest support for this view is the linkage in the floor remarks of the Act's managers between the words "investigating panel" and a special committee of the council. See 126 CoNG. REC. S13,861 (daily ed. Sept. 30, 1980) (statement of Sen. DeConcini) ("The investigating panel 
incorporate in their rules, many councils responded by determining the extent to which statutory procedural rights before a special committee were applicable before the council. Other councils, however, did not even go that far, presumably leaving the matter discretionary. ${ }^{155}$

Notwithstanding the central position of a special committee investigation to the scheme of self-regulation contemplated by the Act, within the decentralized structure of the circuits, only a council has the power to take formal action to remedy problems of misconduct or disability, and any action it takes must be public. ${ }^{158}$ For those reasons, complainants, the subjects of complaints, and the public have a legitimate claim to knowledge of council procedure. And again, the councils have not provided adequate sources of procedural information to supplement council rules.

The rules of many councils may lead those who distrust self-regu-

referred to here is likely to be one appointed by a circuit council pursuant to paragraph (4) of the proposed legislation."); id. at H10,191 (daily ed. Oct. 1, 1980) (statement of Rep. Kastenmeier); see also Third Circuit Rule 1 reporters' note.

If one were to take the view suggested by HOUSE REPORT, supra note 14 , at 14 - that council rules must afford the subject of a complaint and the complainant the rights set forth in $\S \S 372(c)(11)(B) \&(C)$ in council investigations as well as in special committee investigations the major concern would be one of efficiency. Unlike a special committee, however, the council need not undertake an investigation. Compare 28 U.S.C. § 372(c)(5) (Supp. V 1981) with id. $\S 372(c)(6)(A)$. On the other hand, it would be difficult to maintain that, once having determined to conduct an additional investigation, a council could deny a judge or magistrate the right to the exercise of his or her rights "at proceedings conducted by the investigating panel." See supra note 148. But cf. Sixth Circuit Rules 8 \& 10; Eighth Circuit Rules 7 \& 9; First Circuit Rules 9 \& 11, which may take the position that, if a council rejects or closes the complaint, any error is harmless.

One way to avoid this interpretive difficulty and the problems of inefficiency adumbrated here is for the council to remand to a special committee for any additional investigation. See Third Circuit Rule 7(B)(ii). Alternatively, the council could conduct "proceedings" through a committee of less than the whole ("the investigating panel"). Cf. 126 CONG. REC. S13,861 (daily ed. Sept. 30, 1980) (statement of Sen. DeConcini) (contemplating use of "investigating panel" other than the standing committee by the Judicial Conference); id. at H10,191 (daily ed. Oct. 1, 1980) (statement of Rep. Kastenmeier) (same); HOUSE REPORT, supra note 14, at 11 (investigative assistance). Note, however, that no council treating council procedure has so provided. See infra note 157. follows:

168 The councils' actions are summarized in Third Circuit Rule 7(C)(i) reporters' note, as

The Rules of a number of Judicial Councils do not specifically treat the issue of the right of a judge or magistrate to present evidence at the Judicial Council stage, thereby leaving it to discretion on a case-by-case basis. Fourth Circuit Rules $5(B)$ and $6(A)$ afford the judge or magistrate an absolute right to present evidence before the Judicial Council if it conducts additional investigation. Sixth Circuit Rules 8 and 10, Eighth Circuit Rules 7 and 9 and First Circuit Rules 9 and 11 grant a similar right unless the Council rejects or closes the complaint. Paragraph (d) of the Second Circuit Rule affords the same rights to a judge or magistrate (and to a complainant) in any investigation by the Judicial Council as are afforded in an investigation by a Special Committee, "provided that the circuit council may exclude matters which duplicate unnecessarily matters raised before the Committee."

See also the analytical table, infra Appendix A.

168 But see infra note 218 and accompanying text, where problems in the interpretation of $\S 372(c)(15)$ are discussed. It should also be recalled that the Judicial Conference has the power to grant petitions for review. See supra note 85 . 
lation in this area to fear that the subject of a complaint can, by a onesided presentation of evidence ${ }^{\mathbf{1 5 7}}$ or simply by insisting on procedural rights accorded by a council, ${ }^{158}$ induce it not to follow, or to modify, adverse findings and recommendations of a special committee. Council rules that do not elaborate at all the statutorily prescribed procedure are even less likely to inspire public confidence.

The subject of a complaint, on the other hand, is more likely to be concerned that the council will decline to follow the favorable findings and recommendations of a special committee or will increase the sanction recommended in an adverse report. The rules of some councils provide safeguards against arbitrary action, ${ }^{160}$ although the silence of most on the weight to be accorded a special committee's findings and recommendations ${ }^{160}$ may diminish their value. Council rules that do not provide even those safeguards are inadequate from the perspective of judicial independence.

\section{(v) Review Petitions}

Finally, the Act provides that "[a] complainant, judge, or magistrate aggrieved by a final order of the chief judge . . . may petition the judicial council for review."161 The Act speaks not at all to the powers of, or the procedure to be followed by, a judicial council in considering petitions for review. This may explain why Congress, adopting the Conference's language, specifically referred to "the processing of peti-

${ }^{157}$ This might not be a concern if, in undertaking additional investigation, the council were to play the "inquisitorial-administrative" role envisioned in HOUSE REPORT, supra note 14, at 14, quoted supra text accompanying note 117. But see supra text accompanying notes 140-44. Where, as in the Fourth Circuit, provision is only made for the subject of the complaint to appear before the council, that possibility seems remote. See Fourth Circuit Rule 6(A). More generally, in light of the failure of any of the councils' rules to provide that the council may conduct "proceedings" through a committee of less than the whole, an active investigative role for the council seems unrealistic. See supra note 154. Thus, both efficiency concerns and the desire to give the subject of a complaint the right to be heard may skew investigations at this stage.

${ }_{168}$ The costs of "proceedings" before the full council do not require elaboration. They are such as to furnish a strong argument against interpreting $\S \S 372$ (c)(11)(B) \& (C) as applicable at this stage, see supra note 154, and they may deter councils from undertaking additional investigation, if that is effectively the trigger for the exercise of the rights of the subject of a complaint in council rules.

159 See supra note 155. As to the adequacy of the safeguards, cf. supra text accompanying notes 148-51 (special committee procedure).

${ }^{160}$ See supra note 140, where it is argued, however, that a special committee's findings and recommendations should be accorded substantial weight by the council.

Moreover, the safeguards have no value, and the weight to be accorded the report of a special committee assumes particular importance, in cases where a council is not inclined to conduct additional investigation and, in such circumstances, is not required by its rules to afford any rights to the subject of a complaint. See supra note 155 . Consider, for example, a council accepting the findings of a special committee but increasing the recommended sanction.

${ }^{101} 28$ U.S.C. $\S 372(c)(10)$ (Supp. V 1981), quoted supra note 9. 
tions for review" in its grant of rulemaking authority. ${ }^{\mathbf{1 6 2}}$ Almost all councils have, except with respect to minor matters, declined Congress's invitation. ${ }^{163}$ The general considerations suggesting that silence is destructive of the goals of public accountability and judicial independence should by now be clear. It remains to indicate the specific respects in which they are implicated.

Both the state and the pre-Act federal experience provided a basis for prediction that most complaints filed under the Act would be dismissed by the chief judges. ${ }^{164}$ Reported dispositions to date confirm the prediction. ${ }^{185}$ The public has no way of knowing, however, whether the prophecy is self-fulfilling or whether a judicial discipline mechanism is a magnet for frivolous or immaterial complaints. The problem of evaluating complaint dismissals is exacerbated by the Act's substantive ambiguity, the unavailability to the public of dismissal orders and council orders disposing of petitions for review, and the finality of council action on such petitions. ${ }^{166}$ In these circumstances, the review process as-

102 Id. $\S 372(\mathrm{c})(11)$, quoted supra note 11 ; see supra note 109 and accompanying text.

${ }^{103}$ See the analytical table, infra Appendix A. As indicated there, the exception can be found in Third Circuit Rule 9. The Judicial Council of the Ninth Circuit has approved a provision that requires the most senior member of that body (other than the chief judge) to evaluate petitions for review and report on them to the council. It has not, however, approved the final wording of the provision or its location in the council's rules. Telephone interview with Kathleen D. Freeman, law clerk to Chief Judge Browning (Apr. 28, 1983).

104 See House Hearings, supra note 24, at 98 (statement of Chief Judge Browning); id. at 161 (statement of Assistant Attorney General Rosenberg); I. TESITOR, JUDICIAL CONDUCT ORGANIZATIONS 7 (1978), reprinted in House Hearings, supra note 24, at 741; see also TESITOR \& SiNKs, supra note 27 , at 50; Browning, supra note 3 , at 203-04.

${ }_{103}$ See Appendix B; infra note 257.

100 There is no requirement that either a chief judge's order dismissing or closing a complaint or a council's order disposing of a petition for review be made publicly available. See 28 U.S.C. $\S 372(c)(15)$ (Supp. V 1981), quoted supra note 104; supra notes 146 \& 147. Although such orders have been published in the Ninth Circuit, see supra note 147, one respondent to the author's questionnaire, see supra note 121, observed that the council in question, "upon considering the procedures of other circuits . . . decided to treat as confidential a chief judge's order of dismissal." It is only if a council were to grant a petition for review and order action under $\S 372(\mathrm{c})(6)(B)$ that the order would come within the terms of $\S 372(c)(15)$. But such action would be inconsistent with the scheme contemplated by $\S 372(c)(6)$. See Third Circuit Rule 9(G) reporters' note. This is not to advocate publishing such orders, at least if they contain the names of the subjects of complaint. See infra notes 169 \& 217. The orders of the Ninth Circuit Council do not identify the persons against whom complaints were filed.

For the Act's substantive ambiguity, see supra text accompanying notes 82-85, 151.

28 U.S.C. § 372(c)(10) (Supp. V 1981) provides that "[a] complainant, judge, or magistrate aggrieved by an action of the judicial council under paragraph (6) of this subsection may petition the Judicial Conference of the United States for review thereof." Because, except perhaps as suggested supra, action of a council on a petition for review is not "action . . . under paragraph (6) of this subsection," council action on review petitions is final. This interpretation, which is linguistically compelled, finds further support in the last sentence of $\S 372(c)(10)$ : "Except as expressly provided in this paragraph, all orders and determinations, including denials of petitions for review, shall be final and conclusive and shall not be judicially reviewable on appeal or otherwise." See also HOUSE REPORT, supra note 14, at 13. Nothing in the legislative history of the Senate's amendment of this section is to the contrary. See sources cited supra note 99 . Indeed, review by the Judicial Conference would entail one of the evils alleged on behalf of the Conference with respect 
sumes particular importance. In most circuits complainants and the public lack assurance that a chief judge will not participate in decisions on petitions for review and knowledge of the information that will be considered by the council. ${ }^{16 z}$ They are required to accept on faith that informality and collegiality will not lead to ad hoc manipulation.

For the subject of a complaint no less than for a complainant and the public, the Act's substantive ambiguity and the finality of council action impart special importance to the procedure and powers of the judicial council in acting on petitions for review. Judges (and magistrates) are not likely to initiate a petition for review, ${ }^{168}$ but they are vitally interested in the disposition of a petition filed by a complainant. Dismissal not only permits the subjects of complaints to avoid the anxiety, expense, and diversion of judicial energy that attend a special committee investigation; it also protects their good names and permits them to continue doing their share of the other things judges do. ${ }^{169}$ Silence on such questions as the right to file a response to a petition for review holds the prospect of harassment and consequently is a threat to judicial independence. Moreover, silence is difficult to defend by a need to gain experience. Indeed, that concern is of little or no legitimate force in any aspect of the petition process, for which models of obvious rele-

to $S .1873$ as passed in the Senate. See supra note 76. For experience to date, see infra note 265.

107 See the analytical table, infra Appendix A. One respondent to the author's questionnaire, supra note 121, noted that "after canvassing the other circuits, we developed internal procedures for the council's handling of petitions for review of dismissal orders by the chief judge and, in particular, determined that the chief judge could participate in the council's consideration of such petitions for review." But see Third Circuit Rule 9(H); cf. Neisser, supra note 3, at 159-60 (participation in Judicial Conference review of council action by chief judge or district court representative).

1es It is unlikely that judges or magistrates will exercise their right to petition for review because the powers of the chief judge under paragraph (3) are limited to dismissing the complaint or concluding the proceeding if corrective action has been taken.

Nonetheless, to preserve equal treatment between the parties in the process, the right to petition for review of the chief judge's actions to the circuit council is provided to all the individuals involved in the proceedings.

126 CONG. REC. $S 13,860$ (daily ed. Sept. 30, 1980) (statement of Sen. DeConcini); see also id. at H10,191 (daily ed. Oct. 1, 1980) (statement of Rep. Kastenmeier).

${ }_{100}$ There is no requirement that a council order dismissing a petition for review be made publicly available. See supra note 166 . And if published, it need not identify the subject of the complaint. See id. Confidentiality serves a judge's interest as well as the "public interest in avoiding publicity for unfounded charges." WHEELER \& LEVIN, supra note 30, at 62, reprinted in House Hearings, supra note 24, at 682 . In addition, the subject of a complaint dismissed by a chief judge is not "the subject of an investigation" and is therefore not disqualified from serving "upon a special committee . . . upon a judicial council, upon the Judicial Conference, or upon the standing committee established under section 331 of this title, until all related proceedings under this subsection have been finally terminated." 28 U.S.C. § 372(c)(12) (Supp. V 1981). See Third Circuit Rule 10(G); Neisser, supra note 3, at 158. For an account of judges' nonjudicial roles more generally, see Schwartz, The Other Things That Courts Do, 28 U.C.L.A. L. REV. 438 (1981). 
vance are available. ${ }^{170}$

\section{The Benefits of Rulemaking Minimalism Reconsidered}

The costs of rulemaking minimalism are such that the councils' choice is difficult to support. The main argument for that approach that elaborative local rulemaking will produce inappropriate procedural choices - is simply inapplicable to some matters of procedure under the Act. ${ }^{171}$ Moreover it is easy to exaggerate the risks of elaborative rulemaking under the Act. Although some of the possible procedural choices may be unfamiliar, the substantive interests to be served have been defined in a full legislative record. Compared to the problem of foreseeability posed by trans-substantive rules such as the Federal Rules of Civil Procedure, ${ }^{\mathbf{1 7 2}}$ the councils' problem appears trivial. Or at least it does once it is recalled that there is a middle ground between no detail and too much detail, that creeds and catalogues do not exhaust rulemaking alternatives. ${ }^{173}$ Due attention to Congress's purposes and goals suggests that some choices must be made, but they need not deprive special committees or the councils of flexibility to adjust their procedure to the needs of individual cases. ${ }^{124}$

Moreover, the case for the councils' minimalism fails to take account of the relative speed with which council rules can be amended. If for some reason a rulemaking choice has proved unfortunate, the matter can be attended to at the next scheduled meeting of the council or, if the consideration of pending complaints suggests urgency, by other means. ${ }^{175}$

The argument of prematurity also neglects the fact that, in the absence of adequate alternative sources of procedural information, skeletal rulemaking promotes inefficiency as well as uncertainty. The temp-

170 See Third Circuit Rule 9(J) reporters' note; cf. 126 CoNG. REC. \$13,860-61 (daily ed. Sept. 30, 1980) (statement of Sen. DeConcini) (suggesting Supreme Court's certiorari practice as model for Judicial Conference); id. at H10,191 (daily ed. Oct. 1, 1980) (statement of Rep.

Kastenmeier).

171 See, e.g., supra text accompanying note 170.

172 See Cover, For James Wm. Moore: Some Reflections on a Reading of the Rules, 84 YALE L.J. 718 (1975).

${ }_{173}$ "In short, to use Professor Maguire's phrase, the choice is between a catalogue, a creed, and a Code. The Institute decided in favor of a Code." Morgan, supra note 129, at 13.

${ }_{174}$ See 2 K. DAVIS, supra note 107, § 8.7 (2d ed. 1979). "Those who prefer discretion to rules on particular subjects are often victims of the widespread misimpression that rules are necessarily inconsistent with discretion; guiding rules and rules with escape clauses are not inconsistent with discretion." Id. at 186 (emphasis in original); see also infra text accompanying note 195.

${ }^{175}$ Each judicial council is required to meet "at least twice in each year." 28 U.S.C. $\S 332$ (a)(1) (Supp. V 1981). The council can, of course, take action more often, including, presumably, by conference call, mail, or other similar means not requiring travel. Thus, rulemaking under the Act does not confront the problem of long delays that has beset supervisory court rulemaking. See Burbank, supra note 86, at 1020 n.10, 1153-54 n.601; supra note 131. 
tation for the councils to invest as little of their judicial and administrative resources as possible in the elaboration of the Act remains strong in light of the press of other business and the fate of most complaints. But colorable complaints will come, and when they do, lacking direction from the council, special committees will be forced to make up procedure as they go along. Some of the procedural rules thus developed, because they are not authoritative and because the whole process is unfamiliar, are likely to be challenged, delaying the final resolution of a complaint. ${ }^{176}$ Even when the procedural issues in a case have been settled by the council or the Judicial Conference, on this hypothesis there is no way to prevent future challenges.

It is not difficult to imagine the types of challenges that those involved in the process will make to procedure developed by special committees in the absence of prospective rules. The adversary system is all that most American lawyers know, and for that reason alone, they think it best. ${ }^{177}$ In opting for Congress's confusing creed, which imports aspects of traditional adversary procedure, the councils have increased the probability that the model that Congress, in response to judicial importunings, sought to avoid ${ }^{178}$ will in fact predominate. Ironically in light of one suggested reason for the councils' aversion to elaborative rulemaking, formalism is the cure for and not the cause of adherence to the adversary way. ${ }^{178}$

\footnotetext{
178 Moreover, such delay would implicate concerns for judicial independence.

177 Whoever first characterized the continental European system as "inquisitorial" did a profound disservice to constructive legal thought. Substitute "inquiring" and the bad becomes the good. The adversary system is not the only way to the truth; indeed, it has too often been a game in which both sides vie in their efforts to obscure the truth. Hopefully, by the year 2000, we will have learned where to preserve the adversary system and where to substitute something else.
}

Hearings Before the Commission on Revision of the Federal Court Appellate System, second phase, vol. I, at 205 (1974) (statement of Judge Friendly), quoted in Remington, supra note 3, at 728 n.172. This attitude was reflected in comments received on a published draft of the Third Circuit Rules. Many of those submitting comments resisted any departure from the adversary model, even though such departures were authorized, indeed encouraged, by Congress. See supra text accompanying note 117 .

${ }^{178}$ See supra text accompanying notes 94-96.

179 See supra text accompanying note 120.

The discussion thus far may well suggest the question, Why all this care in developing rules of some dynamic content, but susceptible to misinterpretation, whereas a simpler course would be to commit complete discretion to the trial court? The answer is very clear that, without a tradition for the exercise of discretion, a general grant of power is likely to accomplish little. Habitually courts act according to precept and custom. If left to their own devices, without any precise guide beyond a general authorization, they will stick to what they have known in the past. One of the most difficult problems in procedure is to develop a rule sufficiently complex to suggest the various applications to which it is susceptible and yet sufficiently flexible not to restrict. ... .

Clark, supra note 107, at 501 . 


\section{B. Disuniformity}

Local experimentation is bound to result in some national disuniformity. In empowering the Judicial Conference to modify council rules, Congress sought to ensure uniformity on aspects of procedure, in addition to those statutorily prescribed, as to which the benefits of continuing experimentation do not justify its costs. ${ }^{180}$ But Congress also had evidence of the judicial councils' preference for rulemaking minimalism, of "glaring disparities between circuits" with regard to "the elements of the process they cover[ed]" as well as to "the specific procedures they establish[ed]."181 For the Judicial Conference, the silence of most councils' rules on important aspects of procedure is the greatest challenge to the exercise of its statutory powers.

\section{Disuniformity from Conflict in Council Rules}

Consider first those few matters of procedure not covered by the Act on which either enough councils have spoken to create certain disuniformity or the combination of council rules and council silence renders disuniformity probable.

\section{a. No Need for Uniformity: Benefits and No Costs in Continuing Experimentation}

In some instances the potential benefits of continuing experimentation are so obvious, and the costs arising from disuniformity so speculative, that requiring a uniform rule would be premature. For instance, led by the Judicial Council of the Ninth Gircuit, three councils provide for a bankruptcy judge or magistrate to join a special committee in an advisory capacity in investigations involving one of their colleagues. ${ }^{\mathbf{1 8 2}}$

180 See supra text accompanying notes 92-98. In commenting on the councils' post-March 1979 rules, Attorney General Civiletti observed:

There is such disparity among the procedural rules that, in the Justice Department's view, they are likely to produce unexplained inconsistencies in the way different circuits treat similar types of complaints. . . . A major purpose of a mechanism for handling complaints against judges is to enhance the prestige and efficacy of the judiciary as a whole by assuring the public that judges are persons of integrity and ability. Procedures that are incompletely defined and that treat judges inconsistently cannot be expected to enhance public confidence in the judicial system and may even diminish it.

Remarks of Attorney General Civiletti, Annual Dinner in Honor of the Judiciary, ABA Judicial Administration Division (Aug. 4, 1980).

One should add complainants to judges in considering the costs of inconsistent treatment. See also House Hearings, supra note 24, at 161 (statement of Assistant Attorney General Rosenberg).

181 HOUSE REPORT, supra note 14, at 4; see also supra text accompanying notes 61-62.

182 See Ninth Circuit Rule 4(a); Third Circuit Rule 5(B); Eleventh Circuit Rule 4(b). 
Persuaded by the experience in these circuits, other councils may choose to amend their rules, but it is difficult to maintain that they should be required to do so.

\section{b. Uniformity Needed: Costs and No Benefits in Continuing Experimentation}

In other instances, continuing experimentation by the councils augurs no benefits, and the costs of disuniformity are sufficient to suggest the wisdom of a uniform rule. Six councils impose time limits on filing petitions for review from the action of the chief judge. ${ }^{183}$ Here it is the existence, and not the content, of a rule that is most important. ${ }^{184}$ For that reason, what should be said to a complainant in the Second or Seventh Circuit whose petition for review, filed twenty-nine days after entry of the chief judge's order, has been dismissed as untimely and who discovers that the petition would have been timely in the Third, Fourth, Ninth, and Eleventh Circuits? ${ }^{185}$ Where legal rules are essentially arbitrary and cannot even be defended on grounds of sovereign or institutional integrity, one who suffers their consequences is quick to sense inequitable administration of the law. ${ }^{186}$ In this context, such a perception is harmful to the goal of public accountability.

\section{c. The Problem of Unverifiable Benefits}

In still other instances, it is difficult to determine whether the benefits of continuing experimentation exceed the costs of disuniformity to the goals of public accountability and judicial independence. Five councils require that a complaint be verified under oath or signed subject to the penalties for perjury. ${ }^{187}$ Silence in the rules of the others presumably signals the lack of any such requirement. Assuming the councils have free choice on the matter, ${ }^{188}$ it is conceivable, although not likely,

183 See Ninth Gircuit Rule 8 (30 days); Second Gircuit Rule 0.24(b) (20 days); Fourth Circuit Rule 8 (30 days); Seventh Circuit Rule 10 (20 days); Third Circuit Rule 9 (B) (30 days); Eleventh Circuit Rule 8 ( 30 days). These rules are discussed further, from a different perspective, infra text accompanying notes 230-33.

${ }^{184}$ See Miner v. Atlass, 363 U.S. 641, 648-49 (1960).

1 ss In addition, a complainant may wonder if there is any time limit on petitions for review in the six circuits that have not so prescribed by rule.

${ }_{188}$ Cf. Walker v. Armco Steel Corp., 446 U.S. 740, $752-53$ (1980) (refusing to displace state tolling rule in the absence of a pertinent Federal Rule of Civil Procedure).

${ }_{187}$ See Second Circuit Rule 0.24(a); Third Circuit Rule 2(B); Fifth Circuit Rule 24.1; Eleventh Circuit Rule 1; Eighth Circuit Rule 1. There are differences among these rules, although the potential consequences of willful misstatement appear to be functionally indistinguishable. See Third Circuit Rule 2(B) reporters' note. The Eighth Circuit provision results from an amendment on May 17, 1982.

106 Pre-Act Rule A(1) of the D.C. Circuit, see House Hearings, supra note 24, at 451, and the pre-Act procedures of the Fifth Circuit, see id. at 413 , contained such a requirement. The 
that experience could replace reason on the question whether the requirement in fact deters unfounded complaints, the main argument adduced in its favor. ${ }^{189}$ In the meanwhile, however, an informed public will know only that some councils have not deemed an oath or its statutory equivalent necessary to protect judicial independence or judicial resources and thus may regard the requirement as calculated to deter meritorious complaints or as having that effect. Given plausible arguments on both sides, and unless there is a reasonable possibility that continuing experimentation will yield informative data, uniformity is more important than the choice it imposes. The calculus is equally difficult with respect to the issue of anonymous complaints, which are effectively forbidden in seven circuits but may be permitted in the others. ${ }^{190}$

assumption that councils have free choice is reasonable from the perspective of rulemaking authority under the Act. See Third Circuit Rule 2(B) reporters' note. It should be noted, however, that such a requirement was included in S. 1423, supra note 29 (the Nunn/DeConcini bill passed by the Senate in 1978) and in S. 295, supra note 35 (the identical bill introduced in 1979).

The Committee on the Judiciary believes that the requirement that complaints be written and verified or subscribed in the manner prescribed in section 1746 of title 28, United States Code, will tend to reduce the number of frivolous actions filed and if intentional falsehoods are found in a complaint, a conviction based upon a charge of perjury may result.

... If a complainant is unwilling to swear that the statements are "true and correct" to the best of his knowledge, no member of the judiciary should be subjected to the investigation procedures ....

S. REP. No. 1035, 95th Cong., 2d Sess. 22 (1978).

S. 522, supra note 42 , introduced by Senator Bayh, contained, in a proposed amendment adding $\S 332(\mathrm{~g})(1)$, the requirement that each complaint be "in writing and . . . accompanied by supporting affidavits." Senate Hearings, supra note 24, at 163. Judge Hunter approved of this provision, which he interpreted as requiring "the swearing of the complaint." Id. at 29. But Chief Justice Cameron of Arizona criticized the requirement in S. 295 as "unnecessary," nating that the proposed commission would investigate many matters brought to its attention by newspapers or anonymous complaints. See id. at 91; see also id. at 94-95; infra note 190.

1e9 See supra note 188. In fact, given the existence of so many other variables likely to affect the number of complaints filed in a circuit, empirical testing of the hypothesis would be difficult if not impossible.

390 See Ninth Circuit Rule 1; Second Circuit Rule 0.24(a); Fourth Gircuit Rule 1; Third Circuit Rule 2(B); Fifth Circuit Rule 24.1; Eleventh Gircuit Rule 1; Eighth Circuit Rule 1; see also Third Circuit Rule 2(B) reporters' note. The Eighth Circuit provision results from an amendment on May 17, 1982. It is, of course, not clear that silence on the matter in the rules of other judicial councils signifies a willingness to accept anonymous complaints.

At some point in complaint processing, fairness to the subject of a complaint may require disclosure of the name of the complainant, the perception that probably animated pre-Act Rule $E(1)$ of the D.C. Circuit, discussed supra note 115. An argument for receiving anonymous complaints was made at the Senate hearings by Chief Justice Cameron of Arizona:

As a practical matter, the really serious matters that [state] commissions get are usually anonymous. The reason I think is apparent, because the people most likely to know of a serious complaint are part of the courthouse staff or they are attorneys. I would submit to you that no matter how brave a person may be or how supportive of our system he may be, he really is not going to rush out and put his name on a complaint, particularly when he may have some feeling that the complaint may not be acted upon promptly. 


\section{d. Uniformity to Protect Experimentation}

Finally, there are instances in which a uniform rule may serve to ensure the councils' ability to experiment. Three of the councils address the question of the rules of evidence to be applied at proceedings conducted by special committees or by the councils. The First Circuit provides that "[t]he proceedings will be guided by but not bound by the Federal Rules of Evidence."181 The Third Circuit rules state that "[e]xcept where inappropriate, the provisions of the Federal Rules of Evidence shall govern proceedings."102 The Second Circuit, on the other hand, affords a right to the subject of a complaint to require that the Federal Rules of Evidence apply. ${ }^{193}$

When council rulemaking under the Act results in an ascertainable and consequential intercircuit inequality of procedural rights, a perception of unfairness is likely to arise from the differential treatment. ${ }^{194}$ The answer to disuniformity, however, is not to require the greatest level of procedural protection that councils transfixed by the model of adversary court proceedings have seen fit to afford. It is rather to ensure that all councils have in place a rule that provides sufficient predictability and certainty to satisfy the statutory goals of public accountability and judicial independence without depriving special committees or the councils of flexibility - the ability to continue to experiment locally - in investigating complaints. In the case of evidence, the approach of the First and Third Circuits should be preferred to that of the Second. ${ }^{185}$

\section{The Merger of Minimalism and Disuniformity}

Again, however, actual conflict between council rules is the exception. Since most of the councils have chosen not to elaborate the skeletal procedure set forth in the Act, the problems of minimalism and disuniformity merge. The Judicial Conference simply cannot ascertain from council rules, and it is unlikely to learn from other existing

Senate Hearings, supra note 24, at 94.

201 First Circuit Rule 14.

${ }^{102}$ Third Circuit Rules 6(D)(iv), 7(D)(iv). See also Third Circuit Rule 6(D)(iv) reporters' note.

193 See Second Circuit Rules 0.24(c)-(d).

194 Cf. supra text accompanying note 186 (arbitrary rules). This may also be a problem in connection with the rights afforded to the subject of a complaint before a judicial council that has received a special committee's report, if the silence of a number of councils' rules signals an intent to afford rights significantly less protective than those recognized in the rules discussed supra note 155.

${ }^{103}$ See supra text accompanying notes 173-74; note 179; cf. $3 \mathrm{~K}$. DAVIS, supra note 107, $\$ \S 16: 1-: 5$ (rules of evidence in administrative proceedings). 
sources, the extent to which the procedure followed in most aspects of processing complaints differs among the circuits. That is reason enough for the Conference to interpret its powers under the Act broadly. When considered together with the costs of rulemaking minimalism, as such, to the Act's goals, the case for active national leadership becomes compelling. ${ }^{188}$

\section{Inconsistency with the Act}

For rules that, viewed as a whole, depart so little from the statutory framework, the councils' efforts include a surprising number of provisions that conflict with the terms of the Act, are inconsistent with its animating policies, or exceed its grant of rulemaking authority.

\section{Inconsistency with the Act's Provisions}

We need not pause over obvious inconsistencies with the language of the Act that are of little moment, such as the requirement in the rules of one council that a complaint be filed with the circuit executive rather than with the clerk of the court of appeals, as specified in the Act. ${ }^{197}$ Moreover, we should probably treat as inadvertent the failure to include in council rules statutory adverbs designed to speed complaint processing. ${ }^{108}$

106 See supra note 95 and accompanying text. As a start, the Conference should promulgate rules for the conduct of its own business under the Act. But the Standing Committee appointed in 1982, see infra note 265, has reported to the Conference as follows:

The committee has adopted no rules. Indeed, it is seriously doubted that this committee is authorized to adopt rules, for we were authorized only to perform the adjudicatory function of the Conference. At the present time, however, we see no necessity for a body of rules. We believe that we are authorized to obtain supplementation of the records when needed and to hold a hearing in any case in which a hearing woud be appropriate. I can perceive the possible need of a rule regulating the filing of petitions for reconsideration, but we believe that we need more experience before suggesting the adoption of any rule.

Report of the Standing Committee to Review Circuit Council Conduct and Disability Orders (Sept. 1982) (copy on file with the University of Pennsylvania Law Review). The chairman of the committee has recently reaffirmed the position regarding the need for rules. See letter from Hon. Clement F. Haynsworth, Jr., to Stephen B. Burbank (Apr. 22, 1983) (copy on file with the University of Pennsylvania Law Review). For the expectation in Congress that the Conference would promulgate rules, see supra note 109.

${ }^{207}$ See Sixth Circuit Rule 2, which also authorizes filing with the clerk's office "[i]n the absence or unavailability of the Circuit Executive." For the relevant statutory language, see supra note 4.

${ }^{108}$ Compare, e.g., Sixth Circuit Rule 4 and Eighth Circuit Rule 3 and First Circuit Rule 5 with 28 U.S.C. \& 372(c)(3) (Supp. V 1981), quoted supra note 5 (the rules omit the adverb "expeditiously" in connection with review by the chief judge); and id. $\S 372(c)(4)$, quoted supra note 6 (the rules omit the adverb "promptly" in connection with certification of documents to a special committee). For the influence of borrowing, see supra note 126 . For an analysis suggesting that these omissions may not prove as benign as suggested in the text, see Neisser, supra note 3, at 152,156 . For a rule that makes the statutory requirement precise, see Third Circuit Rule 5(D) 
Council rules that omit or imperfectly reflect other statutory requirements are less easily dismissed. The Act forbids a judge or magistrate "whose conduct is the subject of an investigation under this subsection" to serve on a special committee, a judicial council, or the Judicial Conference (or the standing committee authorized by the Act) "until all related proceedings under this subsection have been finally terminated." ${ }^{199}$ Some of the councils' rules do not address the matter. ${ }^{200}$ One of the councils, in addressing it, does not capture the breadth of the statutory disqualification. ${ }^{201}$

It can be argued that disqualification standards are not within the Act's grant of rulemaking authority. Alternatively, it can be argued that council rules should not be expected to incorporate all statutory provisions regarding complaint processing, whether or not within the councils' rulemaking authority. Whatever the merits of those arguments in the abstract - neither supports the partial treatment that has occurred in one circuit - if there ever was a case for incorporation of existing legal prescriptions, even if beyond the power of the rulemakers to formulate, this is it. Incorporation of disqualification standards is desirable in this instance not only for the usual reason, obviating the need to resort to multiple sources of law, but, more important, because it serves Congress's goal of "promot[ing] respect for the principle that the appearance of justice is an integral element of this country's justice system."202

\section{Inconsistency with the Act's Policies}

Apart from inconsistency with the terms of the Act, a number of council rules appear to be inconsistent with its underlying policies.

The fact that the Act provides one mechanism for processing complaints against federal judges and magistrates does not logically require the view that it excludes all other means of self-regulation. Indeed, an

(requiring certification of documents within 5 days of appointment of special committee).

10028 U.S.C. § 372(c)(12) (Supp. V 1981). For an interpretation of the statutory disqualification, see supra note 169 and accompanying text.

${ }^{200}$ See the rules of the Sixth, Eighth, and D.C. Circuits. For the influence of borrowing, see supra note 126.

201 See First Circuit Rule 9 ("Judges who are subjects of the complaint shall not be eligible to vote."). Of course, neither here nor elsewhere is there reason for council rules to include statutory requirements applicable to the Judicial Conference. $C$. infra text accompanying notes 241-42 (inappropriateness of council rules prescribing time limits on petitions for review to the Judicial Conference).

202 HOUSE REPORT, supra note 14, at 1 , quoted in part, supra note 14 . On the incorporation principle, see Burbank, supra note 86 , at $1147-57$. For disqualification rules going beyond those required by the Act, see Third Circuit Rules $9(\mathrm{H}) \& 10(\mathrm{G})$.

For other material omissions in council rules, see supra note 153. See also supra note 154. 
interesting question arises concerning the residual powers of the councils to deal with such problems. ${ }^{203}$ Whatever the answer to that question, the provision in one council's rules authorizing a chief district judge to receive a complaint and to "take such action as is appropriate" is very difficult to support. ${ }^{204}$ Passing the problem that authority for such a rule must be found outside the Act, ${ }^{208}$ the rule itself disregards

203 See 28 U.S.C. $\S 332$ (d)(1) (Supp. V 1981); HOUSE REPORT, supra note 14, at 8-9. The House report may be thought to suggest broad power in the councils to deal on their own motion with matters that could also properly be grounds for a complaint under the Act. See also Third Circuit Rule 2(B) reporters' note ("the procedures set forth in these Rules do not affect other powers of the Judicial Council, including the power to hold hearings, to take sworn testimony, and to issue subpoenas and subpoenas duces tecum under 28 U.S.C. § 332(d)"). Moreover, the Act contemplates that a council will acquire information suggesting the need for disciplinary action in ways other than consideration and investigation of a complaint. See 28 U.S.C. $\S 372(c)(7)$ (B) (Supp. V 1981).

On the other hand, although the universe of those who may file a complaint ("any person") includes the Chief Judge and other members of a council, sua sponte investigations outside the complaint mechanism established by the Act are problematical. S. 1873 authorized the councils to investigate allegations on their own motion, but it contemplated such investigations with a view to filing a complaint "if appropriate." S. 1873, supra note 1 (proposing amendment adding 28 U.S.C. § 372(c)(4)), reprinted in House Hearings, supra note 24, at 312-13; see SENATE REPORT, supra note 60 , at 8 .

In distinguishing between situations in which a council may act under $\S 332$ (d) and those in which it must act, if at all, under $\S 372(\mathrm{c})$, one can rely on a distinction between judicial administration and judicial discipline only by ignoring the argument that the Act's discipline mechanism is, in fact, designed primarily to serve the goals of judicial administration. See supra text accompanying notes 70-74; 94-96. Moreover, resort to $\S 332$ (d) could lead to an evasion of the Act's procedural protections and the "excesses" that prompted Congress to embrace them. See supra note 96 and accompanying text; cf. Neisser, supra note 3, at 157-58 (28 U.S.C. § 372(c)(7)(B)). A test focusing on remedial action is unsatisfactory, if only because the sanctions enumerated in § 372(c)(6) are not exclusive.

Dangers of another sort would be implicated if a council's powers under $\S 332(d)(1)$ were invoked at the behest of a judge initiating "an investigation into his own conduct where, for example, he ha[d] been accused of improper conduct by a reporter," House Hearings, supra note 24, at 70, as proposed in the Third Circuit before the Act was passed. See id. Among them, public accountability would not be well served by an investigation conducted without a complainant alleging a real grievance and without any provision for outside monitoring.

Apart from other modes of self-regulation, conduct with which the-Act is concerned may be made the subject of a complaint to law enforcement authorities or to the House of Representatives. See HOUSE REPORT, supra note 14, at 13.

204 (i) Nothing in this rule precludes a person from filing in the first instance a complaint with respect to a district judge or magistrate with the chief judge of the district court involved, or a complaint with respect to a bankruptcy judge with the most senior bankruptcy judge of the court involved, in which event the chief judge of the district court or most senior judge of the bankruptcy court to which the complaint is addressed may take such action as is appropriate. Any judicial officer aggrieved by such action may petition the chief judge of the circuit in writing for a review thereof under section (b) of this rule. A complainant dissatisfied with the disposition of a complaint may subsequently initiate the procedures provided for by this rule.

Second Circuit Rule 0.24(i). Rule 0.24(b) implements 28 U.S.C. $\$$ 372(c)(3) (Supp. V 1981), quoted supra note 5 . This Article does not address that part of the rule that relates to bankruptcy judges.

${ }^{203}$ See 28 U.S.C. $\S 372(c)(11)$ (Supp. V 1981), quoted supra note 11. The Second Circuit Rule cannot fairly be said to concern "the conduct of proceedings under this subsection." Moreover, against the argument that it merely preserves power found elsewhere, note that such power 
the statute's background and legislative history in at least three respects. First, it derogates from Congress's purpose to provide an authoritative and efficient mechanism for processing formal complaints. ${ }^{208}$ Second, it makes more difficult the attainment of Congress's goal of public accountability and the means chosen to achieve that goal, including publicity and oversight. ${ }^{207}$ Third, it may be seen as a threat to judicial independence not contemplated by Congress. ${ }^{208}$ All of this is not to say that chief district judges have no role to play in resolving problems of alleged misconduct or disability. ${ }^{209}$ Formally to assert by rule power that is doubtful, ${ }^{210}$ to authorize a competing mechanism that is procedure-less and the operations and results of which are totally insulated from public scrutiny, and to sanction another layer of regulation for federal judges is, however, to fail to heed the lessons of the Act's history. One of those lessons is not to confuse influence with power.

is doubtful, see infra note 210 , and that the rule purports to authorize a chief district judge to "take such action as is appropriate."

206 See supra text accompanying notes $14,76 \& 83-84$; notes $85 \& 175$. The Second Circuit Rule discussed supra note 204 does contemplate that a complaint may end up being processed as provided in the Act. But it adds another layer to that process.

207 See supra text accompanying notes $100 \& 106$.

208 See supra text accompanying notes 87-91; supra note 206: Compared with Second Circuit Rule 0.24(i), Ninth Circuit Rule 2, requiring that a copy of a complaint against a district judge or magistrate be transmitted to the "chief judge of the district concerned," is a small point at which to stick. But see Third Circuit Rule 3(B) reporters' note:

Although there may in an appropriate case be occasion for consultation by the Chief Judge with the chief judge of the district concerned, a uniform notice requirement does not seem necessary and may not be desirable in light of concerns expressed, during the formulation of the Act, about the independence of individual federal judges.

${ }^{208}$ See 28 U.S.G. $\S 372(\mathrm{c})(6)(B)(i)$ (Supp. V 1981). Wheeler and Levin are correct in asserting:

[J]udicial discipline mechanisms must harness and preserve the best qualities of informal methods of dealing with problem judges. Formal mechanisms with triggers so sensitive as to preclude the operation of these informal devices will drain the system's total capacity to achieve effective judicial discipline. Particularly when formal mechanisms cast a judge and his colleagues in an adversary role, with the procedural corallaries [sic] that implies, they serve to abort informal processes that could have been more effective and less burdensome to the system itself. In short, the effective administration of the judicial system should continue to benefit from - and place reliance in - the capacities of individual judges to alert colleagues to problems of their behavior, or of their physical or mental condition, that must be dealt with, although often by measures less drastic than retirement or resignation.

WHEELER \& LEVIN, supra note 30, at 74, reprinted in House Hearings, supra note 24, at 694; see also 126 CoNG. REC. S13,859-60 (daily ed. Sept. 30, 1980) (statement of Sen. DeConcini).

But Second Circuit Rule 0.24(i) purports to establish a formal mechanism in addition to that prescribed in the Act and to confer power on chief district judges.

${ }^{210}$ It is difficult to imagine a plausible argument that chief district judges have inherent power in this area. Moreover, a list of "U.S. Code Sections Affecting Chief District Judges" furnished to the author by the Federal Judicial Center reveals no such authority in existing statutory law. A copy of the list, which was prepared in connection with an ongoing project of the Center and may be revised, is on file with the University of Pennsylvania Law Review. 
Other council rules present closer questions of consistency with the Act's policies. ${ }^{211}$ For example, the rules of two councils authorize such restrictions on disclosure as the councils deem appropriate in providing written notice to a complainant of council action in a matter upon which a special committee has made a report. ${ }^{212}$ These same councils' rules also authorize withholding the name of the judge involved in the written order of such action required to be made available to the public by the Act. ${ }^{213}$

The Act must be read to permit the anonymity of a judge or magistrate when the council's action is a censure or reprimand "by means of private communication," sonable for a council to attempt to ensure, although it is not clear that it has the power to enforce, confidentiality on the part of the complainant. ${ }^{215}$ With that exception, required to reconcile conflicting provisions resulting from a Senate amendment to the House bill, these council rules may conflict with the purpose of that amendment. Identifying a judge or magistrate would not be necessary if the amendment's only purpose was, as it may have been, to provide "public access to the process created by this legislation." 216 But identification would seem to be important if public accountability, like judicial independence, is thought to have both institutional and individual aspects. ${ }^{217}$ Moreover, argu-

212 In addition to the rules discussed in the text, see, e.g., Second Circuit Rule 0.24(b) (authorizing chief judge to refer complaint to screening panel consisting of one circuit judge and one district judge for review and recommendation); Eleventh Circuit Rule 3(c) (same); Eighth Circuit Rule 3 (authorizing chief judge to conduct "preliminary investigation"). The Act does not empower a chief judge or his delegate to conduct an investigation, preliminary or otherwise, except for the purpose of performing his limited role under 28 U.S.C. \$ 372(c)(3) (Supp. V 1981). See Third Circuit Rule 4(B) reporters' note; supra note 169

${ }^{212}$ See Ninth Circuit Rule 6(C); Fourth Circuit Rule 6(C). The Act requires a council "immediately [to] provide written notice to the complainant and to such judge or magistrate of the action taken under this paragraph." 28 U.S.C. $\$ 372(c)(6)(C)$ (Supp. V 1981), quoted supra note 7.

213 See Ninth Gircuit Rule 6(D); Fourth Circuit Rule 6(D). For the Act's publicity requirements, see 28 U.S.C. $§ 372$ (c)(15) (Supp. V 1981), quoted supra note 104. For the Act's confidentiality requirements, see id. $\S 372(\mathrm{c})(14)$, quoted supra note 103.

21428 U.S.C. $\S 372(c)(6)(B)(v)$ (Supp. V 1981), quoted supra note 7; see Third Circuit Rule 7(G); Third Circuit Rule 7(G) reporters' note ("[The Rule] tracks 28 U.S.C. $\$ 372(c)(15)$, accommodating the evident inconsistency between that section . . and . . . $3372(\mathrm{c})(6)(\mathrm{B})(\mathrm{v})$, providing for censure or reprimand by 'private communication.' "); see also Neisser, supra note 3, at 158-59.

${ }^{210}$ But cf. SENATE REPORT, supra note 60 , at 16 (suggesting that one who violated the confidentiality provisions of $S$. 1873, supra note 1 , could be found in contempt); Third Circuit Rule 6(F) (providing for transmittal of copy of special committee's report to complainant and subject of complaint under confidentiality order); supra note 146.

210126 CONG. REC. S13,861 (daily ed. Sept. 30, 1980) (statement of Sen. DeConcini); id. at

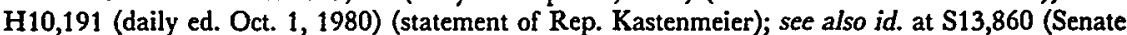
amendments require "the procedures and institutions involved to be more open to public scrutiny"); id. at H10,191 (same); House Hearings, supra note 24, at 174 (statement of Rep. Kastenmeier).

217 See SENATE REPORT, supra note 60, at 5. 
ments for confidentiality as a means to induce acquiescence by the subject of a complaint, particularly in disability cases, are weakened by the statutory provision permitting a council's order to omit reasons when the interests of justice so require. ${ }^{\mathbf{2 1 8}}$ But the legislative history is hardly decisive. Given this uncertainty about Congress's purpose and the force of an argument for individual public accountability, the asserted power to withhold the name of the subject- of an investigation and to impose restrictions on disclosure should be exercised only in the exceptional case.

The rules of two councils deal with the question of attorney's fees. The Judicial Council of the District of Columbia Circuit has deter-

In this context, informal systems, such as the largely behind-the-scenes activities in the federal courts, can have two major problems. First, would-be complainants have no knowledge of how and where to express their grievances. Second, while the public may have a general feeling that there are problems on the bench, it normally has little knowledge that specific problems have been identified and dealt with. In other words, the barrier to public satisfaction is not in the actions taken but in the lack of communication about those actions. The defects can be remedied, albeit within limits. For example, the Judicial Conference of the United States recommended in March, 1979 that each of the circuits consider the "promulgation of rules of procedure for the receipt and processing of complaints against judges." Such promulgation is unlikely to accomplish the whole task. It is not to be expected that the public can be easily educated to the causes of dissatisfaction that should be immune from discipline - e.g., unpopular decisions - and the areas properly in the cognizance of judicial discipline. Explaining why judges were not disciplined, however, presumably would serve an educational role.

WHEELER \& LEVIN, supra note 30, at 68 (footnote omitted), reprinted in House Hearings, supra note 24 , at 688 .

We are not here concerned with a judge's interest or the "public interest in avoiding publicity for unfounded charges." Id. at 62, reprinted in House Hearings, supra note 24, at 682; see also supra notes $166 \& 169$.

218 See 28 U.S.C. § 372(c)(15) (Supp. V 1981), quoted supra note 104. It is unclear why this provision was deemed necessary if it was contemplated that the name of a judge could be withheld. It may have been feared that in a rare case disclosure of reasons could prejudice an ongoing criminal investigation, a possibility even if the subject of the complaint were not identified. But, whatever Congress's purpose in adding this provision, it would appear largely to meet arguments like those suggested in the text. For an elaboration of those arguments, see House Hearings, supra note 24, at 167-68 (statement of Assistant Attorney General Rosenberg). Note in that regard that S. 1873, supra note 1, upon which Mr. Rosenberg was commenting, provided for confidentiality unless disclosure was authorized in writing by the subject of a complaint, unless the judge was censured or reprimanded by means of public announcement, or unless "final adverse action" was taken against him. S. 1873 (proposing amendment adding $\S 372(\mathrm{n})$ ), reprinted in House Hearings, supra note 24, at 322-23.

The Act's public availability provision presents other serious interpretive problems. See Neisser, supra note 3 , at 158-59. The suggestion that the statutory requirement of public availability may be limited by distinguishing statutorily enumerated "actions" from statutorily enumerated "orders," see id., would seem to founder on discontinuities between the dichotomy effected thereby and the dichotomy suggested by the Senate and House managers' references to "sanctioning action[s]." See 128 CONG. REC. S13,861 (daily ed. Sept. 30, 1980) (statement of Sen. DeConcini); id. at H10,191 (daily ed. Oct. 1, 1980) (statement of Rep. Kastenmeier). In context, both references seem to contemplate that all actions under $\S 372(c)(6)(B)$ will be implemented by order. But cf. $\$ 372(c)(10)$ (referring to "a final order of the chief judge" but also to "an action of the judicial council under paragraph 6 of this subsection"). 
mined that the subject of an investigation "shall receive payment of attorney's fees in accordance with procedures established by the Director of the Administrative Office of the United States Courts" and would permit an "investigating panel," in its discretion, to authorize a complainant appearing before it "to request payment of attorney's fees" from the Director. ${ }^{219}$ The Judicial Council of the Third Circuit provides that "[a] Special Committee or the Judicial Council, as the case may be, shall have the discretion to authorize the payment of attorney's fees for a complainant or for a judge or magistrate whose conduct is the subject of a complaint."220

The Act does not specifically treat the issue of attorney's fees, and the legislative history is not helpful. The strongest support for the power to pay such fees comes from a statement in the Congressional Budget Office Cost Estimate that is part of the House report. ${ }^{221}$ To extrapolate, however, from this statement to congressional purpose requires quite a leap, particularly when one notes that the statutory provision directing the Director of the Administrative Office to pay "out of funds appropriated for the operation and maintenance of the courts" refers to "necessary expenses incurred by the judicial councils of the circuits and the Judicial Conference under section 372 of this title, including mileage allowance and witness fees."222 To argue that attorney's fees are "necessary expenses" as a general proposition is a bootstrap operation. The inference of congressional purpose becomes even more attenuated when it is recalled that S. 1423, the Nunn/DeConcini bill passed by the Senate in the Ninety-Fifth Congress, provided reimbursement of attorney's fees for a judge or Justice who was the subject of a complaint only if that complaint was "finally dismissed."223

219 D.C. Circuit Rules 5(C), 5(E). The difference between the two rules makes clear that the Judicial Council of the D.C. Circuit has made a categorical judgment that the subject of a complaint is entitled to attorney's fees in every case and that the only function of the Administrative Office is to prescribe procedures for payment.

220 Third Circuit Rule 10(H).

221 "Based on information from the Administrative Office of the U.S. Courts, it is also expected that the government will provide the judge assistance by counsel, resulting in estimated costs of over $\$ 100,000$ in the first year." HOUSE REPORT, supra note 14, at 22; see also id. at 20 ("[T]he committee agrees with the cost estimate of the Congressional Budget Office."); SENATE REPORT, supra note 60, at 19 (Congressional Budget Office Report).

At the House hearings, Assistant Attorney General Rosenberg urged the subcommittee to consider "whether, if a complaint relates to a judge's conduct in an official capacity, the judge should be provided with representation at public expense on the same terms that currently apply in civil suits against agents of the federal government." House Hearings, supra note 24, at 164.

22228 U.S.C. $\S 604$ (h)(1) (Supp. V 1981) (added by Pub. L. No. 96-458, § 5, 94 Stat. 2035, 2040 (1980)); see HOUSE REPORT, supra note 14, at 16; see also SENATE REPORT, supra note 60 , at 17.

${ }^{223}$ See S. REP. No. 1035, 95th Cong., 2d Sess. 60 (1978); S. 295, supra note 35, § 391(d), reprinted in Senate Hearings, supra note 24, at 154.

A judge or Justice may only receive attorneys' fees under this section if a complaint 
At the most, the Act and its legislative history support the payment of attorney's fees when "necessary" to the achievement of the Act's purposes and goals, a determination to be made by, or pursuant to standards approved by, the Director of the Administrative Office. ${ }^{224} \mathrm{Al}$ though that standard does not exclude prospective categorical judgments, the Nunn/DeConcini bill suggests that whatever judgment is expressed in the District of Columbia Circuit Council's rule requiring payment of attorney's fees is too broad. The flexible approach reflected in that council's discretionary rule and in the rule of the Third Circuit Council more nearly accords with the admittedly ambiguous evidence of congressional purpose, and even that approach is subject to challenge. ${ }^{225}$

finally is dismissed. Therefore, if the commission dismisses a complaint but the court remands the matter for further investigation and the judge ultimately is censured, no attorneys' fees are to be provided. The entitlement to attorneys' fees arises only once the matter ultimately is resolved.

S. REP. No. 1035, 95th Cong., 2d Sess. 43 (1978).

224 See supra text accompanying note 222; $c f$. the Federal Courts Improvement Act of 1982, Pub. L. No. 97-164, § 116(a), 96 Stat. 25, 32:

Whenever a Chief Justice, justice, judge, officer, or employee of any United States court is sued in his official capacity, or is otherwise required to defend acts taken or omissions made in his official capacity, and the services of an attorney for the government are not reasonably available pursuant to chapter 31 of this title, the Director of the Administrative Office of the United States Courts may pay the costs of his defense. The Director shall prescribe regulations for such payments subject to the approval of the Judicial Conference of the United States.

This provision contemplates litigation, not an "inquisitorial-administrative" proceeding such as that contemplated by the Act, a fact that the reference to chapter 31 of title 28 makes clear. See 28 U.S.C. $\$ 516$ (1976); S. REP. NO. 275, 97th Cong., 1st Sess. 15-16 (1981); Regulations of the Director, Administrative Office of the United States Courts, Governing the Retention of Private Counsel to Represent Judges of the United States and Court Employees Sued in their Official Capacities $\S 1.2$ (copy on file with the University of Pennsylvania Law Review) ("sued . . . or ... otherwise required to defend in litigation."); see also id. $\$ 2.5$ (mandamus). These regulations were approved by the Judicial Conference. Report of the Proceedings of the Judicial Conference of the United States 76 (Sept. 1982). Nonetheless, the provision suggests an appropriate means of dealing with requests for attorney's fees under the Act until such time as there is statutory clarification. In that regard, the Director's regulations provide standards and procedures governing both requests for legal representation and compensation of private counsel.

Finally, Third Circuit Rule 10(H) can, but need not, be read to arrogate final decision on payment - subject always to the availability of funds - to the council. The preferable reading, however, is that the rule, like D.C. Circuit Rule 5(E), provides for first-level approval, subject to final action by the Director.

${ }^{228}$ See supra note 223. Although the contexts are quite different, it is interesting to note that the proponents of the bill, eventually passed as the Rules Enabling Act of 1934, giving the Supreme Court of the United States supervisory rulemaking power in civil actions at law may have believed that such matters as costs and fees were beyond the power conferred by that bill. See S. REP. No. 1174, 69th Cong. 1st Sess. 10-11 (1926); Burbank, supra note 86, at 1084 n.297. The original Advisory Committee on Civil Rules was of the same view with respect to the amount of, and items taxable as, costs. See letter from William D. Mitchell to Charles E. Clark (Oct. 13, 1937) (Charles E. Clark Papers, Yale University Library, box 111, folder 58); Burbank, supra note 86 , at 1137 n.541.

An inference of lack of authority under S. 1423, see supra note 223, may be warranted by the placement of the provision regarding attorneys' fees in a section ( $\$ 391$ ) conferring rulemaking 


\section{Ultra Vires}

Finally, a few of the rules promulgated by the councils exceed the authority conferred by the Act or present problems of authority that deserve attention. ${ }^{226}$

The Act's rulemaking grant extends to "rules for the conduct of proceedings under this subsection, including the processing of petitions for review."227 Congress contemplated rules "establishing procedures for the filing of complaints . . . and for the investigation and resolution of such complaints." ${ }^{228}$ Neither the language Congress employed, nor the Act's legislative history, nor the history of other rulemaking grants to the federal judiciary supports the notion that, under this grant, the councils have the power to make rules of substantive law, as for instance by elaborating the statutory standards of misconduct or disability. ${ }^{228}$ That task remains with Congress, through amendments to the Act, or with the councils and the Conference through the resolution of individual complaints. Moreover, an analysis of and experience under other rulemaking grants suggests considerable doubt that it was Congress's purpose to confer power on the councils to make rules having what might be called predictable and identifiable substantive side effects. ${ }^{230}$

authority. Alternatively, the purpose may have been to foreclose any other rulernaking choices. A rule like that of the Third Circuit, supra text accompanying note 220, makes no choices and therefore may be less vulnerable to challenge from the perspective of rulemaking authority. $C$. Burbank, supra note 86, at 1184, 1193 (Rules Enabling Act of 1934). It may still, however, be invalid if, as a matter of statutory interpretation, the councils are found to lack the power ever (that is, even on a case-by-case basis) to authorize reimbursement of attorneys' fees.

256 In addition to the rules discussed in the text, see supra notes $188 \& 205$ and accompanying text.

29728 U.S.C. \& 372(c)(11) (Supp. V 1981), quoted supra note 11.

228 Id. at $\S 372(\mathrm{c})(17)$ (rules for specialized courts).

250 See, e.g., HOUSE REPORT, supra note 14, at 13-14; id. at 4; supra text accompanying notes 92-95; cf. Burbank, supra note 86, at 1121-25 (Rules Enabling Act of 1934). Congress contemplated the "building of precedents" by the Judicial Conference, exercising its power to grant petitions for review. See 126 CONG. 'REC. S13,858 (daily ed. Sept. 30, 1980) (statement of Sen. DeConcini).

That is not to say, of course, that Congress could not have conferred such power on the councils, if, that is, they are not thought to be acting as article III courts in performing the tasks assigned by the Act. Unfortunately, there is a mystifying (and obviously misplaced) footnote in the House report suggesting that the councils exercise judicial power. See HOUSE REPORT, supra note 14 , at 15 n.35. But see, e.g., id. at 14; Senate Hearings, supra note 24, at 58 (statement of Chief Judge Browning). Rather, in granting authority to promulgate "rules for the conduct of proceedings," Congress has not made such a delegation. Cr. Pickus v. United States Board of Parole, 507 F.2d 1107, 1113 (D.C. Cir. 1974) ("[A] matter 'relating to practice or procedure' means technical regulation of the form of agency action and proceedings ... [and] does not include formalized criteria adopted by an agency to determine whether claims for relief are meritorious.").

2s0 See Burbank, supra note 86, at 1127-29 (Rules Enabling Act of 1934); Wright, Procedural Reform: Its Limitations and Its Future, 1 GA. L. REV. 563, 569-71 (1967) (limitations on procedural reform). 
In this light, the Fifth Gircuit Council's rule requiring that a complaint "be filed within one year of the action complained of"231 is of doubtful validity. Rules limiting the time within which a complaint may be filed are examples of rules that, although possessed of a procedural aspect, are nevertheless so intertwined with the substantive law as to fall outside of a rulemaking grant that seeks to allocate power by reference to a dichotomy, however imprecise, between procedure and substance. ${ }^{232}$ For that reason, even under the Rules Enabling Act of $1934,{ }^{233}$ a rulemaking grant that has been aggrandized and obscured, the Supreme Court has been alert to the far less consequential limitations implications of a provision: of the Federal Rules of Civil Procedure. ${ }^{234}$

A chief judge and the council of a circuit may have the power to dismiss an individual complaint as untimely by reference to considerations captured in the equitable doctrine of laches, applied to the facts in the light of Congress's purpose to secure the efficient and expeditious resolution of complaints. ${ }^{285}$ But that is not the regime suggested by the Fifth Circuit's rule. If, as may well be, the policies typically animating a statute of limitations are thought to have particular force in this context, suggesting that at some point the need for certainty and predictability is greater than the need to ensure public accountability, Congress should amend the Act. ${ }^{238}$

Given this analysis of a rule limiting the period within which complaints may be filed, the question arises whether the far more numerous council rules limiting the time for filing petitions for review from the action of a chief judge can be sustained. ${ }^{237}$ Notwithstanding attempts to justify similar rules in other contexts by reference to the fact of an "already existing action,"

231 Fifth Circuit Rule 24.1.

232 See Burbank, supra note 86, at 1128.

28328 U.S.C. § 2072 (1976).

2s4 See Ragan v. Merchants Transfer \& Warehouse Co., 337 U.S. 530 (1949) (FED. R. GIV. P. 3); Walker v. Armco Steel Corp., 446 U.S. 740 (1980) (same); Burbank, supra note 86, at 1131-84, 1158-60.

${ }^{223}$ Cf. Neisser, supra note 3, at 160 (petitions for review).

2s6 The concern that a judicial discipline mechanism might be used to harass federal judges, a concern implicating judicial independence, suggests the wisdom of a limitations period. Cf. supra note 76 and accompanying text (speedy dismissal of frivolous complaints). But particularly because public accountability is so poorly served by a prospective rule fashioned by judges, the choice should be made by Congress. Moreover, claims of both misconduct and disability might well be predicated on a course of action (or inaction) the consideration of which should not be foreclosed by the deadline chosen, unless it is a long one.

237 These rules are considered from a different perspective supra text accompanying notes 183-86.

238 Kaplan, Amendments of the Federal Rules of Civil Procedure, 1961-63 (pt. 2), 77 HARV. L. REV. 801,810 (1964). But see Burbank, supra note 86, at 1156 n்.607. 
what harder for relevant distinctions. It would help if council rules included a provision making explicit a power to enlarge limitations periods. ${ }^{239}$ In any event, a relevant distinction does subsist in the differing probabilities of notice of such a period on the part of an actual complainant seeking review of the order of a chief judge as compared with a putative complainant who has not been alerted to the possibility that rights under the Act may be cut off by "procedural" rules. ${ }^{240}$

A similar problem arises with respect to time limits imposed by some councils on petitions for review to the Judicial Gonference from council action. ${ }^{241}$ But here one need not pause over nice distinctions. The councils have no business making rules governing petitions for review to the Judicial Conference. ${ }^{242}$

\section{Public Accountability}

Implicated in many aspects of procedure under the Act, ${ }^{243}$ the goal of assuring public accountability is not restricted to the process of resolving complaints. In response to widespread criticism of, and congressional interest in, court rulemaking, it has been observed that the public has little constructive to offer in the formulation of procedural rules. ${ }^{244}$ Whether or not that contention is true, consultation in the development of procedural rules to implement a statute that avowedly respects appearances more than reality ${ }^{245}$ cannot be dismissed as a futile

2s* Cf. FED. R. APP. P. 4(a)(5) (authorizing a district court, "upon a showing of excusable neglect or good cause," to "extend the time for filing a notice of appeal upon motion filed not later than 30 days after the expiration of the time prescribed by this Rule 4(a)."); Burbank, supra note 86, at 1156 n.607 (Rules Enabling Act of 1934).

240 C. Burbank, supra note 86, at 1156 n.607, 1170 n.666 (Rules Enabling Act of 1934). But see Neisser, supra note 3, at 160 . Third Circuit Rule 2(B) requires that all complaints "be filed on forms provided, together with a copy of these Rules, through the office of the clerk of the Court of Appeals." In addition, the rules require specific notice of rights to the complainant and the subject of the complaint. See Third Circuit Rules 4(D), 5(E), 7(B)(iii); Third Circuit Rule 4(D) reporters' note.

241 See Ninth Gircuit Rule 8; Second Circuit Rule 0.24(e); Fourth Gircuit Rule 8; Eleventh Circuit Rule 8.

112 The Judicial Conference has the power to prescribe rules, 28 U.S.C. $\S 372$ (c)(11) (Supp. V 1981), quoted supra note 11, and Congress expected that it would exercise that power. See supra note 109. An argument by analogy to former Federal Rule of Civil Procedure 73(a), abrogated by the Supreme Court's Order Prescribing the Federal Rules of Appellate Procedure, 389 U.S. 1065, 1065-66 (1967), fails because both involved an exercise of supervisory rulemaking power by the Supreme Court, predicated in part on a need for uniformity.

Third Circuit Rule 7(B)(iii) requires the Judicial Council to include with its order "notice of any right to petition the Judicial Conference for review under 28 U.S.C. $\$ 372(c)(10) . "$

s4s Sec, e.g., supra text accompanying notes 140-47, 157-58 \& 164-67; see also supra text accompanying notes 183-90, 202, 207, 211-18 \& 236.

24. See Hazard, Book Review, 87 YALE L.J. 1284, 1290-92 (1978).

36s In a very real sense the problem addressed in the Act is more one of perception than actuality - the need to assure the public that procedures are in place to deal with the rare instance justifying an inquiry related to the condition or conduct of a 
or cynical gesture. For the same reason, and as a measure of protection against a flood of misdirected complaints, one could hope for efforts to bring the existence of the Act and council rules (or council procedure more generally) to the attention of the public that go beyond the minimum required by Congress. ${ }^{246}$ Finally, in light of explicit indications of abiding congressional concern, ${ }^{247}$ self-interest would also suggest the wisdom of candor in providing the information necessary to evaluate this experiment in judicial self-regulation.

\section{Rulemaking Process}

Of the eleven councils that have revised their rules to implement the Act, only three solicited public comment on drafts of such rules. ${ }^{248}$ Moreover, notwithstanding the clear prospect of congressional action to ensure extra-judicial participation in the rulemaking process in closely allied areas, ${ }^{249}$ only three of the councils submitted drafts of their rules to advisory committees. ${ }^{250}$ Indeed, six of the councils did not even seek the comments of all federal judges in the circuit, and seven did not include bankruptcy judges and magistrates in the group consulted. ${ }^{251}$ These statistics tend to confirm the suggestion that one purpose of many councils was to have a set of rules, any set of rules, in place when the Act became effective. ${ }^{252}$ They are cause for concern not only from the perspective of public accountability. Many of those who will be the subjects of complaints were denied the opportunity even to offer their

member of the judiciary. Stated another way, the growing public demand for the accountability of public officials should extend to the judicial branch.

SENATE REPORT, supra note 60, at 5; see also HOUSE REPORT, supra note 14, at 4, 19-20.

216 28 U.S.C. \$ 372(c)(11) (Supp. V 1981), quoted supra note 11, requires that "[a]ny rule promulgated under this subsection . . . be a matter of public record." See HOUSE REPORT, supra note 14, at 14. For the role that increased publicity could play in reducing the number of complaints, see infra text accompanying note 258 . As to council procedure more generally, see \$ 372(c)(15), quoted supra note 104; supra note 147 and accompanying text; infra note 258.

217 See supra text accompanying notes 16 \& 100-06.

218 Responses to questionnaire, supra note 121. In one case, the public notice and request for comment went only to bar associations. In the other two cases, the notice was much more broadly disseminated, including by a press release. The Tenth Circuit is not included in this calculation. See supra text accompanying note 18 ; note 123 .

210 See the Federal Courts Improvement Act of 1982, Pub. L. No. 97-164, § 208, 96 Stat. 25, 54-55: "(b) Each court of appeals shall appoint an advisory committee for the study of the rules of practice and internal operating procedures of the court of appeals. The advisory committee shall make recommendations to the court concerning such rules and procedures." Although not enacted until 1982, this provision was part of S. 1477, supra note 1, with the contents and history of which the federal judiciary had good reason to be conversant both generally and as it bore on judicial councils. See supra note 1.

${ }^{280}$ Responses to questionnaire, supra note 121.

281 Responses to questionnaire, supra note 121.

${ }^{262}$ See supra text accompanying note 121. 
views on the shape of council rules. ${ }^{253}$

\section{Publicity}

Three councils provided no public notice of the adoption of final rules to implement the Act. ${ }^{254}$ In others, the notice was so restricted as to be unlikely to reach a substantial portion of the bar or the public. ${ }^{25 s}$ It is, of course, true that the Act requires only that council rules be "a matter of public record."256 And it is probably the case that anyone determined to make a complaint will ultimately be directed to the appropriate clerk's office. Further, the morale of the federal judiciary is a legitimate concern, and a flood of misdirected complaints could hardly improve it. But public awareness of the statutory mechanism was Congress's goal. Quite apart from the statutory goal, a less defensive posture by the councils might reduce the number of clearly improper complaints. The experience to date suggests that complainants have not yet heard the message that the Act does not provide a substitute for appeal from a decision or procedural ruling. ${ }^{257}$ Undoubtedly, some will be immune to that message. But others might be dissuaded from filing if the

26s In its 1974 statement of "Powers, Functions and Duties of Circuit Councils," see supra note 37, the Conference took the position that "[b]efore the circuit council adopts any general order affecting the operation of the courts within its circuit, the judges of the district courts should be afforded an opportunity to comment. In appropriate cases it will also be desirable to afford an opportunity for comment to the bar and public groups known to be concerned." Report of the Proceedings of the Judicial Conference of the United States 9 (Mar. 1974).

28s Responses to questionnaires, supra note 121. In all three, there was also no public notice of, or an invitation to comment on, a draft. As a result, in these circuits at least, it remains true that "the existence of the remedy . . . for dealing with improper judicial conduct, through judicial councils of the circuits, is not well known . . . to the public." House Hearings, supra note 24, at 85 (statement of Chief Judge Browning).

The March 1979 resolution of the Judicial Conference advised that council rules "should be announced in such manner as to assure that the public and the bar will be informed." Report of the Proceedings of the Judicial Conference of the United States 5 (Mar. 1979); see also FLANDERS \& MCDERMOTT, supra note 39 , at 34 ; WHEELER \& LEVIN, supra note 30 , at 68 , quoted supra note 217.

${ }^{265}$ Responses to questionnaire, supra note 121 . In one circuit, a copy of the rules was sent to all attorneys admitted to practice. In others, notice was published in legal newspapers, an announcement was made at the circuit judicial conference, or the like. It does not appear that all of the councils' rules have been published in sources widely available. See supra note 18.

The notion that all or most complainants will be attorneys or that they will be represented by attorneys is dubious. The former can be tested empirically. See infra text accompanying note 266. A survey of complaint dispositions by state commissions in 1981 indicates that "the vast majority of complaints are filed by litigants, their friends or relatives, and witnesses. Individual attorneys, nonlitigating citizens, and commissioners themselves comprise the next most frequent sources of complaints." JUDICIAL CONDUCT REPORTER, Fall 1982, at 2.

23e See supra note 246.

237 The table compiled by the Administrative Office of the United States Courts for the ninemonth period October 1, 1981 through June 30, 1982 shows that of 67 complaints dismissed by chief judges (out of a total filed of 89), 43 made allegations directly related to the merits of a decision or procedural ruling. See Appendix B. In fact, the number may be higher. See infra text accompanying note 262 . 
limited jurisdiction as well as the existence of the Act were publicized and if aspiring complainants were individually furnished with a copy of council rules and a complaint form with instructions. ${ }^{258}$

\section{Data for Oversight}

The Act requires the Director of the Administrative Office of the United States Courts to "include in his annual report filed with the Congress under this section a summary of the number of complaints filed with each judicial council ... indicating the general nature of such complaints and the disposition of those complaints in which action has been taken." ${ }^{259}$ To compile that report for the nine-month period ending June 30,1982, the Administrative Office developed two forms for completion by each council, one calling for a summary of information with respect to the entire reporting period, to be filed annually, and the other for information with respect to each complaint filed, to be filed quarterly. ${ }^{260}$ On the basis of the completed forms, the Director included in his report for fiscal year 1982 a table and an explanatory note. ${ }^{261}$

A significant deficiency in the Director's table and in the summary form is the failure to include in the category of complaints concluded or dismissed by the chief judges complaints that are subsequently brought to the councils by petition for review. The result is that the number of dismissals by chief judges almost surely is artificially deflated. ${ }^{\mathbf{2 6 2}}$

A related problem is the inability of a reader of the table or the summary form to determine with confidence the action taken by a

288 See Third Circuit Rule 2; Eighth Circuit Rule 1. Both councils have adopted complaint forms with instructions. The forms specifically note the Act's limited jurisdiction. The Eighth Circuit's form results from an amendment on May 17, 1982.

Another means to give publicity to these matters is publishing orders dismissing complaints. See supra notes 147 \& 166; see also House Hearings, supra note 24, at 98 (statement of Chief Judge Browning); WHEELER \& LEVIN, supra note 30 , at 68 . This is not a common practice, however, and it is unlikely to prove effective for prospective complainants who are not, or are not represented by, attorneys. See supra note 255 .

25828 U.S.C. $\S 604(\mathrm{~h})(2)$ (Supp. V 1981); see supra text accompanying note 102.

$200 \mathrm{See}$ letter from William E. Foley to Hon. Collins J. Seitz (July 1, 1982) (copy on file with the University of Pennsylvania Law Review). Copies of both the summary form (Form A.O. 372A) and the individual form (Form A.O. 372B) are also on file. The completed individual forms filed with the Administration Office are confidential. See id.

s61 See Appendix B.

282 Footnote 12 to the table, infra Appendix B, indicates that the category of "Dismissals" includes "[d]ismissals affirming a chief judge's final order, or pursuant to petition for review, or based upon an independent council decision." Thus, it may well be that more than 67 complaints were dismissed by chief judges because, where a petition for review was taken to a council, that action was attributed to the council. See supra note 257 . Thus the explanatory note to the table may be misleading in stating: "There were 78 complaints concluded during the nine month period. All, except 11, were disposed of by chief judges. . . The remaining 11 were disposed of by judicial councils." See Appendix B. 
council on petitions for review. ${ }^{283}$ Review petitions should receive discrete attention, as they do, albeit to a limited extent, on the individual form. ${ }^{264}$ Until such time, however, as there are uniform rules governing petitions for review, it is doubtful that the information provided would be of much use. ${ }^{285}$

Neither the table nor the summary form provides any information with respect to complainants. The individual form does call for such information, but there may not be enough categories to tell the Administrative Office much about the people who file complaints. ${ }^{286}$ In any

${ }^{203}$ In connection with dismissals, it is unclear whether the councils have denied a petition for review from dismissal by the chief judge, granted a petition but affirmed dismissal by the chief judge, or granted a petition and dismissed where the chief judge concluded the proceeding having found that appropriate corrective action had been taken (the only action other than dismissal that can ground a petition for review).

184 The individual form (Form A.O. 372B) contains boxes to check under the heading "Complaint Considered by Judicial Council" labelled as follows: "Referred by Chief Judge - 372(c)(4) and 372(c)(5)" and "Following Petition for Review - 372(c)(10)." For congressional interest in petitions for review to the Judicial Conference, see 126 CoNG. REC. S13,860-61 (daily ed. Sept. 30, 1980) (statement of Sen. DeConcini); id. at H10,191 (daily ed. Oct. 1, 1980) (statement of Rep. Kastenmeier); see also supra note 85.

ses Except in the Third Circuit, the procedures to be followed by, and the powers of, judicial councils in considering petitions for review are not defined, at least in rules promulgated pursuant to the Act. See supra note 163 and accompanying text. In such circumstances, it would be difficult indeed to obtain useful statistical information.

Still another defect in the table is the failure to include any information regarding petitions for review filed with the Judicial Conference under 28 U.S.C. $\$ 372(c)(10)$ (Supp. V 1981), quoted supra note 9. It was not, however, until after the reporting period that the Conference determined how to proceed. In July 1982 the Conference's Executive Committee created a standing committee to review petitions, as authorized by 28 U.S.C. \& 331 (Supp. V 1981). See Memorandum to all Chief Judges, Circuit Executives and Clerks from William E. Foley (Aug. 25, 1982) (copy on file with the University of Pennsylvania Law Review). At the Chief Justice's direction, all such petitions are to be filed with Mr. Foley at the Administrative Office of the United States Courts. Id. As of April 22, 1983, the Standing Committee had disposed of five petitions for review. See letter from Hon. Clement F. Haynsworth, Jr., to Stephen B. Burbank, supra note 196. The Committee's orders are public documents on file in the Administrative Office. In one case (No. 82-372-002) the petition was dismissed for want of jurisdiction because the petitioner had failed to seek review of a Chief Judge's dismissal by the judicial council of the circuit. In another case (No. 82-372-001) the Committee reviewed and upheld the dismissal of a complaint against all active members of the Court of Claims. In the three remaining cases (No. 82-372-003, 004, 006), the Committee reviewed and upheld, or after review on the merits denied a petition for review of, dismissals that had been upheld by judicial councils. At least in the last group of cases, the Committee should have dismissed the petitions for want of jurisdiction. See supra note 166. It appears that, having subsequently "closely examined our jurisdiction to review affirmations by judicial councils of authorized dismissals of complaints by chief circuit judges," letter from Hon. Clement F. Haynsworth, Jr., to Stephen B. Burbank, supra note 196, the Committee will dismiss for want of jurisdiction in future cases. See id.; Report of Standing Committee to Review Circuit Council Conduct and Disability Orders (Mar. 1983) (copy on file with the University of Pennsylvania Law Review).

For the expectation in Congress that Conference or standing committee orders.would serve as "precedents," see supra note 85 . Query whether they can do so if not widely and regularly circulated.

${ }^{260}$ The individual form (Form A.O. 372B) contains boxes to check under the heading "Complainant" labelled as follows: "Prison Inmate," "Attorney," "Public Official," and "Other." It might be useful to add, at the least, "Civil Litigant" and "Criminal Defendant or Person under Criminal Investigation." 
event, if a substantial number of complainants are disgruntled losers in litigation or prisoners with little else to do but file complaints, the judiciary would be well served by public knowledge of those facts.

The table and the summary form do not speak to the nature of complaint allegations except in categories that, as applied to alleged misconduct, are of almost meaningless generality. ${ }^{267}$ The individual form calls for more particularized information, which is essential if one is to begin to monitor the interpretation of the Act's substantive standard at a critical stage. ${ }^{268}$

Neither the table nor the summary form provides useful information regarding special committee or council investigations, and it is not clear what information the individual form calls for in that respect. ${ }^{269}$ Again, differences among the rules and practices of the councils make the collection of useful statistical information difficult if not impossible.

287 The table and the summary form (Form A.O. 372A) permit identification of the "Nature of Allegations" as follows: "Mental Disability," "Physical Disability," "Other Allegations Within Section 372 Jurisdiction," and "Allegations Not Within Section 372 Jurisdiction." See Appendix B.

${ }^{20 s}$ For the problems presented by the Act's substantive ambiguity in connection with dismissals, see supra text accompanying notes 164-70.

The individual form (Form A.O. 372B) contains boxes to check under the heading "Complaint Allegation" as follows: "Mental Disability," "Physical Disability," "Decisional Delay," "Demeanor," "Conflict of Interest," "Prejudice or Bias," and "Other (briefly state gravamen of the major allegation)." If such information is to be useful in summary, however, there must be a means to relate it to the grounds upon which complaints are dismissed. Moreover, problems of multiple complaint allegations, multiple subjects of complaints, and multiple grounds of dismissal must be addressed. The table reveals 102 complaint allegations against 168 individuals in 89 complaints. See also Table 30 explanatory note, Appendix B. The author has been informed by the staff of the Administrative Office, which prepared the table, that, where a complaint was dismissed on multiple grounds, the ground corresponding to the highest numbered footnote in footnotes 1 to 4 was used.

For one approach to the problem of multiple subjects of complaint, see Instructions to Third Circuit Complaint Form: "Only the conduct of one judge or magistrate may be challenged in your complaint. If you seek to challenge the conduct of different judges or magistrates, you must file separate complaints as to each judge or magistrate." See also Third Circuit Rule 10(A) (joinder), 10(B) (severance).

${ }^{288}$ It is, of course, possible to make inferences from both the table and the summary form (Form A.O. 372A), but one must be careful. Thus, it is virtually certain that action by a judicial council under 28 U.S.G. $\S 372$ (c)(6) (Supp. V 1981), quoted supra note 7, will have been preceded by a special committee investigation, but see supra note 166 , and one can therefore make that assumption regarding the cases enumerated in connection with footnotes 5 through 11 in the table and the summary form. See Appendix B. Other cases in which a special committee investigation has occurred could, however, be lumped with "Dismissals" (footnote 12). See supra notes 262 \& 263. Moreover, no inferences can be made regarding council investigations.

The individual form (Form A.O. 372B) provides space for information regarding "Hearings before a special committee or the council (enter number)" as follows:

Judge or magistrate Requested Granted

Complainant

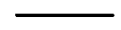

In light of problems of definition arising from the use of the word "hearings," cf. supra note 148 ("proceedings"), and the failure to separate special committees and councils, this information is unlikely to be useful with respect to an individual complaint, let alone for statistical purposes. 
Information on these matters would nevertheless be of interest to one assessing the operation of the statutory mechanism and in particular its costs. ${ }^{270}$

In sum, neither the categories of information included in the Director's table nor those collected by the Administrative Office are adequate for a comprehensive assessment of the operation of the Act, now or in the future. Congress cannot rely on data provided pursuant to the Act for effective oversight. Congress can, of course, request additional information. The federal judiciary has misapprehended its best interests in failing to volunteer, or at least to collect, some of that information. For the rest, we must await more detailed and uniform council rules. Indeed, the effect of statistical problems of the sort discussed here on congressional oversight provides another argument for such rules.

\section{CONCLUSION}

Measured against criteria of adequacy of detail, innovativeness, and consistency with the Act's provisions and policies, the rules promulgated by the judicial councils of the circuits are, taken as a whole, deficient. As a result, exercising its negative powers - to prevent disruptive disuniformity and modify rules that are inconsistent with the Act - may not be the most important, although it is an essential, role for the Judicial Conference to play. The choice of most of the judicial councils not to elaborate the statute in detail can be supported by traditional wisdom. The uncertainty and unpredictability resulting from the councils' minimalism, however, entail costs beyond those traditionally associated with nonformalism. ${ }^{271}$ They threaten purposes central to the Act.

Criticism of the councils' rulemaking under the Act should not obscure the fact that federal judges are hard pressed to stay abreast of strictly judicial business. ${ }^{272}$ The councils may still be inadequately staffed to accomplish their tasks. ${ }^{273}$ Until such time as they-are able to devote serious attention to prospective procedural lawmaking at the local level, the impetus of, and the resources available to, a Conference initiative may be necessary if the problems described here are to be addressed. ${ }^{274}$ At that, one need not be cynical about motivation to un-

${ }^{270}$ See supra notes $155,157 \& 158$.

271 See sources cited supra note 129.

${ }^{272}$ See, e.g., Remarks of Chief Justice Burger, The Arthur T. Vanderbilt Dinner (November 18, 1982) (copy on file with the University of Pennsylvania Law Review).

s7s See 28 U.S.C. \& 332(e)-(f) (1976); FLANDERS \& MCDERMOTT, supra note 39, at 30-31, 70-71, 194.

274 An instructive analogy lies in comparing federal supervisory court rulemaking with federal local court rulemaking. In part, the difference in quality may be attributable to the greater 
derstand why, particularly in light of the experience under the Act to date, ${ }^{275}$ this Article may be regarded as the luxury of an academic. The question, however, is whether Congress will acquiesce in the judiciary's priorities. The alternative to central judicial leadership may be further action by Congress. ${ }^{276}$

Using existing council rules as a "Chinese menu,", the Conference could fashion a uniform yet flexible procedure that would meet most of the concerns raised here. ${ }^{278}$ It is to be hoped, however, that if

investment of time and resources devoted to the formulation of rules at the national level. In part, it may be attributable to the greater number of people who are consulted about such rules. In addition, is it inconceivable that federal judges simply are not very good at prospective lawmaking? If so, that is another argument for broadening the base of those involved in the formulation and consideration of rules. I am indebted to my colleague, Daniel Segal, for encouraging me to think the unthinkable. See also supra text acoompanying notes 248-53. On federal supervisory court rulemaking, see W. BROWN, supra note 107 ; J. WEINSTEIN, supra note 107; Burbank, supra note 86 , at 1018-21, 1095. On federal local court rulemaking, see J. WEINSTEIN, supra note 107, at 117-45; Flanders, supra note 108.

${ }^{273}$ See supra text accompanying note 15 ; note 257.

276 Thus far, most councils have not amended their rules, and the amendments that have been made are of limited extent. See supra notes 163,187, 190 \& 258. Moreover, the earlier history of council efforts in this area is hardly promising. See, e.g., supra text accompanying note 98. Even on the assumption that the councils' rulemaking minimalism is predicated on a desire to learn from experience, see supra text accompanying notes 117-19, the question recurs when there will have been enough experience under the Act to prompt elaborative rulemaking by the councils. See supra note 147. Most complaints filed to date have been dismissed or concluded by the chief judges, see supra note 257; that is, they have not reached the stage at which the Act and most councils' rules cease to provide adequate procedural information. See supra text accompanying notes 132-38.

Congress was, with good reason, unwilling to await experience under the post-March 1979 rules of the councils, which were perceived to be inadequate. See supra text accompanying notes 15-16 \& 58-65. The inadequacies of the councils' rules implementing the Act, albeit less egregious, are nevertheless damaging to the Act's policies and goals. For that reason, Congress is unlikely to heed pleas for more time. Indeed, it is striking that, even before the Act's effective date, representatives continued to introduce bills proposing alternatives to the Act's scheme of self-regulation. See H.R. 1658, 97th Cong., 1st Sess. (1981) (introduced by Rep. Pease); H.R. 2799, 97th Cong., 1st Sess. (1981) (introduced by Rep. Oakar). For a more recent proposal, see H.R. 6942, 97th Cong., 2d Sess. (1982) (introduced by Rep. Findley).

Of course, whether or not the Conference plays an active supervisory role, it should set its own house in order. See supra note 196.

On alternative sources of procedural information, see supra text accompanying notes 147, $150,166 \& 258$.

${ }^{272}$ House Hearings, supra note 24, at 182 (statement of Assistant Attorney General Rosenberg).

${ }_{278}$ See supra text accompanying notes 174 \& 195; see also, e.g., Third Circuit Rules 6(D) (special committee proceedings), 9 (review petitions).

Eminent authority cautions against confusing the number of procedural rules with the question whether they are "too detailed in the regulation they provide." Wright, Modern Pleading and the Pennsylvania Rules, 101 U. PA. L. REV. 909, 912 (1953).

But this cannot be proven by a mere counting of rules, as is shown by the usual rules on discovery of the modern pleading systems; these systems usually have twelve such rules, with numerous subsections, spelling out in considerable detail the kinds of discovery available, even though "it might have been possible or even desirable to have provided one single broad rule authorizing all forms of discovery in any civil action." Yet the effect of all these rules is not to limit the trial court's discretion or the parties' freedom, but rather to make clear just how great this discretion and 
the Conference were moved to undertake the formulation of uniform rules, it would take advantage of its greater resources and prestige more broadly to canvass the range of procedural options available and that, where appropriate, the Conference would afford choice on those options to the councils. ${ }^{278}$

Whether or not the Conference takes a broad view of its mandate under the Act, its leadership should extend to rulemaking procedures. The Conference has shown responsiveness to criticisms of the process by which federal supervisory court rules are formulated and thus has set further in relief local court rulemaking. ${ }^{280}$ In most circuits the public has had no chance to affect the content of procedural rules implementing the Act and may not even be aware of its existence. In many, federal judges not on the council and magistrates have also not been consulted. If the Conference intends to do more than eliminate unwarranted disuniformity and invalidity from council rules, the public should have an opportunity to participate in that process. In any event, the Conference should encourage, and may have the power to require, the councils to open up their own rulemaking processes - for example, by publishing their existing rules for public comment. ${ }^{281}$ This is not the time to disparage appearances in rulemaking. ${ }^{\mathbf{2 8 2}}$

Finally, the Conference should assist the Administrative Office in ensuring the provision of information that is useful in evaluating experience under the Act. That such information is not now required by Congress is beside the point. Public awareness of experience to date might well be of use to the judiciary. In addition, the information may soon be requested by Congress, and the inability of the Administrative Office to comply will ill serve the interests of the judiciary. We are here not concerned with appearances. Congress and the public have a right to know whether the Act's experiment in self-regulation is working.

freedom are. Thus, these rules do not offend the criterion suggested above.

Id. at 912-13 (footnote omitted); see also supra note 179 .

270 The major constraint in such an enterprise would be the problem of disuniformity arising from the choice of different alternatives by the councils. That is, the Conference should not permit choice on such matters as time limitations for filing petitions for review to the council where the benefits of continuing experimentation do not justify the costs of disuniformity. See supra text accompanying notes 183-86.

${ }_{280}$ See Burbank, supra note 86 , at 1021, 1095; see also supra note 274.

${ }^{281}$ See 28 U.S.C. $\S 331$ (Supp. V 1981), quoted in part supra note 11; id. at § 372(c)(11), quoted supra note 11 . Three councils did solicit public comment on draft rules. See supra text accompanying note 248 .

${ }_{233}$ See supra text accompanying notes 243-47. 


\section{APPENDIX A}

\section{Explanation of Table}

The table illustrates the implementation of the Act by each judicial council that revised its rules after the Act was passed and by the specialized courts. The Tenth Circuit is not included. The table highlights the major changes in, whether departures from or additions to, the statutory framework. The purpose of the table is to alert the reader to changes of a material nature. For further analysis, reference to the rule itself (noted to the left of indicated changes) is recommended. Relevant statutory provisions are listed in the column entitled "Statutory Provisions."

Minor discrepancies that conceivably could have material consequences have been omitted. For example, some circuits omit the words "expeditiously" and/or "promptly" from their versions of the statutory sections. Although omission of this language may be relevant in determining the timeliness of an action, for the purposes of this table it is not considered material.

The annotation "NC" denotes "no change" from the statutory framework. This could indicate either that a circuit council (or specialized court) has copied the Act verbatim or that, despite differences in language, no material modification has occurred. In the case of the specialized courts, some changes were necessary to accommodate differences in structure; such changes are not considered material.

Annotations only reflect changes. Where, for instance, one change is noted, it should be assumed that in all other respects the council rule tracks the statutory provision.

In two instances, the analysis of council rules includes matters not covered in the Act. See "Review Petitions: Time" and "Miscellaneous" in the "Statutory Provisions" column.

\section{Commonly Used Abreviations}

$\begin{array}{ll}\text { BJ } & \text { Bankruptcy Judge } \\ \text { C } & \text { Complainant } \\ \text { CBJ } & \text { Chief Bankruptcy Judge } \\ \text { CDJ } & \text { Chief District Judge } \\ \text { Certif } & \text { Certification } \\ \text { CEx } & \text { Circuit Executive } \\ \text { CirJ } & \text { Circuit Judge } \\ \text { CJ } & \text { Chief Judge } \\ \text { Cplt } & \text { Complaint } \\ \text { Cross-ex } & \text { Cross-examination } \\ \text { DJ } & \text { District Judge } \\ \text { FRE } & \text { Federal Rules of Evidence } \\ \text { J } & \text { Judge whose conduct is the subject of a complaint } \\ \text { JC } & \text { Judicial Council } \\ \text { M } & \text { Magistrate whose conduct is the subject of a complaint } \\ \text { NC } & \text { No Change } \\ \text { NRR } & \text { No Relevant Rule } \\ \text { PO } & \text { Presiding Officer } \\ \text { SpC } & \text { Special Committee within the meaning of (c)(4) }\end{array}$

\section{Notes}

2 Incorporates provisions of the Act by reference. In the case of the Fifth Circuit, there are only four stated rules. Fifth Circuit Rule 24.5 provides that "[a]ll other proceedings shall be conducted in accordance with the provisions of subsection (c)."

- The Chief Judge of the Second Circuit appointed a standing special committee for the first year of operation of the procedures.

- The extent to which the Act prescribes procedural rights before the Judicial Council, and hence the extent to which rules contain "major changes in, whether departures from or additions to, the statutory framework," is unclear. See supra note 154 and accompanying text. 


\section{APPENDIX B}

\section{REPORT OF COMPLAINTS FILED AND ACTION TAKEN \\ UNDER TITLE 28 U.S.C. $372(c)^{*}$}

The Judicial Councils Reform and Judicial Conduct and Disability Act of 1980 (Public Law 96-458) requires that the Director of the A.O. include in the Annual Report a summary of the number of complaints filed under Title 28 U.S.C. Section 372 (c), as amended by the Act, indicating the general nature of the complaints and the disposition of those complaints. Since the Act became effective on October 1, 1981, this first report covers the nine month period ended June 30 , 1982.

During the nine month period covered by this report, there were 89 complaints filed with clerks of court. There were 56 allegations of conduct prejudicial to the effective and expeditious administration of the courts; one allegation that a judicial official was unable to discharge all duties of the office by reason of physical disability; 45 allegations not within Section 372 jurisdiction; and no allegations of mental disability. The 89 complaints included allegations against 51 courts of appeals judges, 75 district court judges, 8 national court judges, 9 bankruptcy judges, 11 magistrates, and 14 others. The number of allegations and number of officials involved exceed the number of complaints because some complaints contain more than one allegation and name more than one judicial official.

There were 78 complaints concluded during the nine month period. All, except 11, were disposed of by chief judges as not in conformity with filing requirements under Title 28 U.S.C. Section $372(c)$ (1), directly related to the merits of a decision, frivolous, or because the chief judge found that appropriate action had already been taken. The remaining 11 were disposed of under Title 28 U.S.C. Section $372(\mathrm{c})(6)(B)(i i i)$, requesting voluntary retirement. There were no referrals to the Judicial Conference.

There were 11 complaints pending at the end of the year. Seven involved allegations against district judges, two against bankruptcy judges and two against magistrates.

Table 30 contains a summary of the complaints filed, disposed of, and pending for each circuit and each of the national courts.

- Source: 1982 ANN. REP. DIRECTOR AD. OFF. U.S. CTS. 65-67. 
Table 10

Us. Table 10

Report of compinints Filed and Action Taken

.

Marike the Nine Month Period Ended June 30, 1982

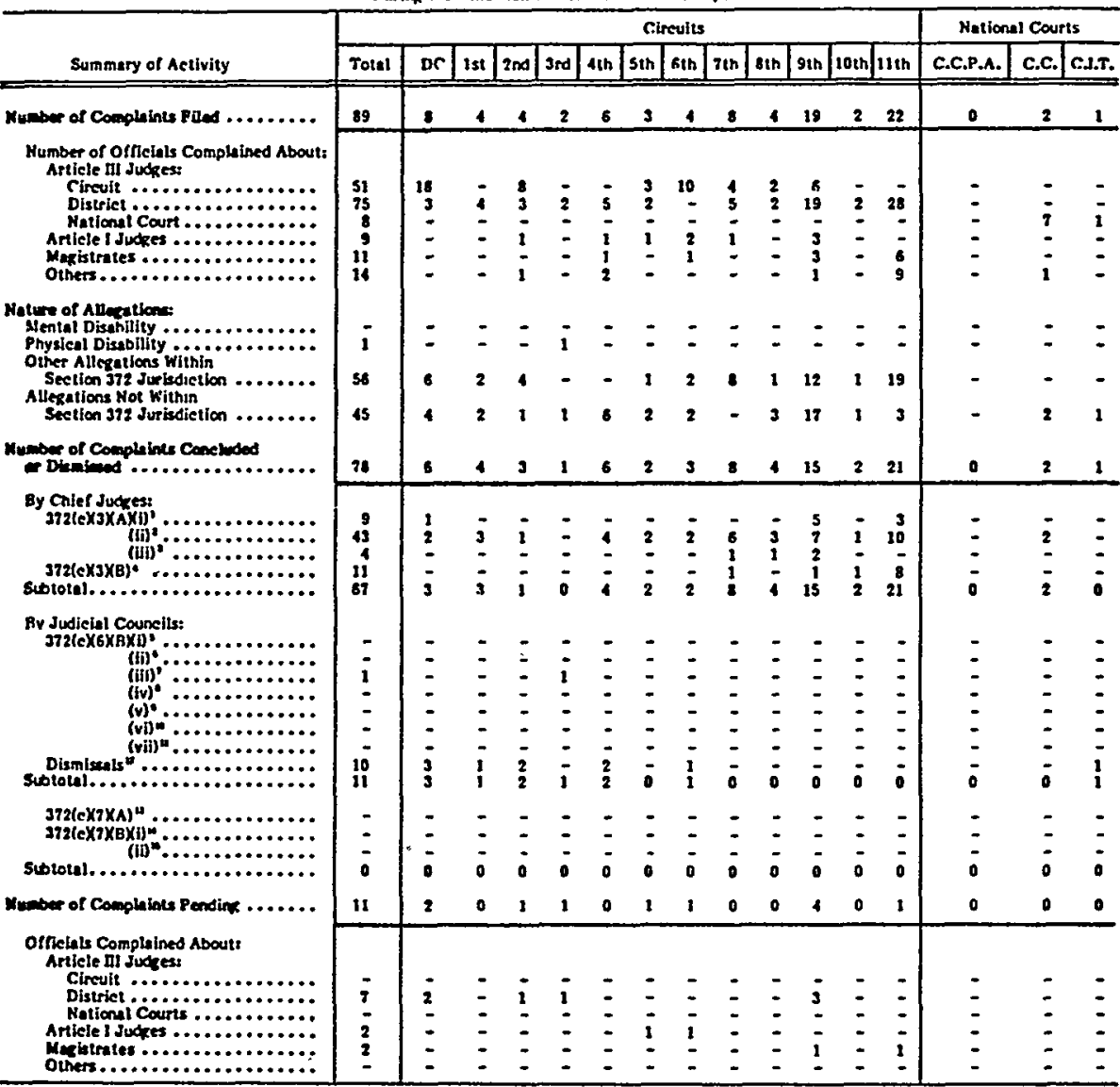

C.C.PA. - Court of Customs and Patent Appents

C.C. - Court of Clalas

Cl.T. - Court of Internutional Trade

wotet see following page for explanation of complaints concluded. 


\section{Footnotes for Table 30}

1

Not in conformity with requirements of Title 28 U.S.C. 372(c)(1): a brief written statement filed with clerk of court of appeals alleging conduct prejudicial to the effective and expeditious administration of the business of the courts, or alleging inability to discharge all the duties of office by reason of mental or physical disability.

Directly related to the merits of a decision or procedural ruling.

Frivolous,

Appropriate corrective action has been taken.

Directing the chief judge of the district to take appropriate action with regard to a magistrate who is the subject of a complaint.

Certifying disability of an Article III judge.

Requesting the voluntary retirement of an Article III judge, with the provision that the length of service requirements under Title 28 U.S.C. Section 371 shall not apply.

Ordering that no further cases be assigned for a temporary or time-certain period.

9 Censuring or reprimanding by means of private communication.

10 Censuring or reprimanding by means of public announcement.

11 Ordering such other action as is dee med appropriate to assure the effective and expeditious administration of the business of the courts within the circuit, but not dismissals.

12 Dismissals affirming a chief judge's final order, or pursuant to petition for review, or based upon an independent council decision.

Discretionary referral to the Judicial Conference.

14 Mandatory referral to the Judicial Conference upon a finding that an Article III judge has engaged in conduct that might constitute a ground for impeachment.

Mandatory referral to the Judicial Conference upon a finding that an Article III judge has engaged in conduct which is not amenable to resolution by the Judicial Council. 